Prepared in cooperation with North Dakota State University Extension Service

\title{
Runoff and Water-Quality Characteristics of Three Discovery Farms in North Dakota, 2008-16
}
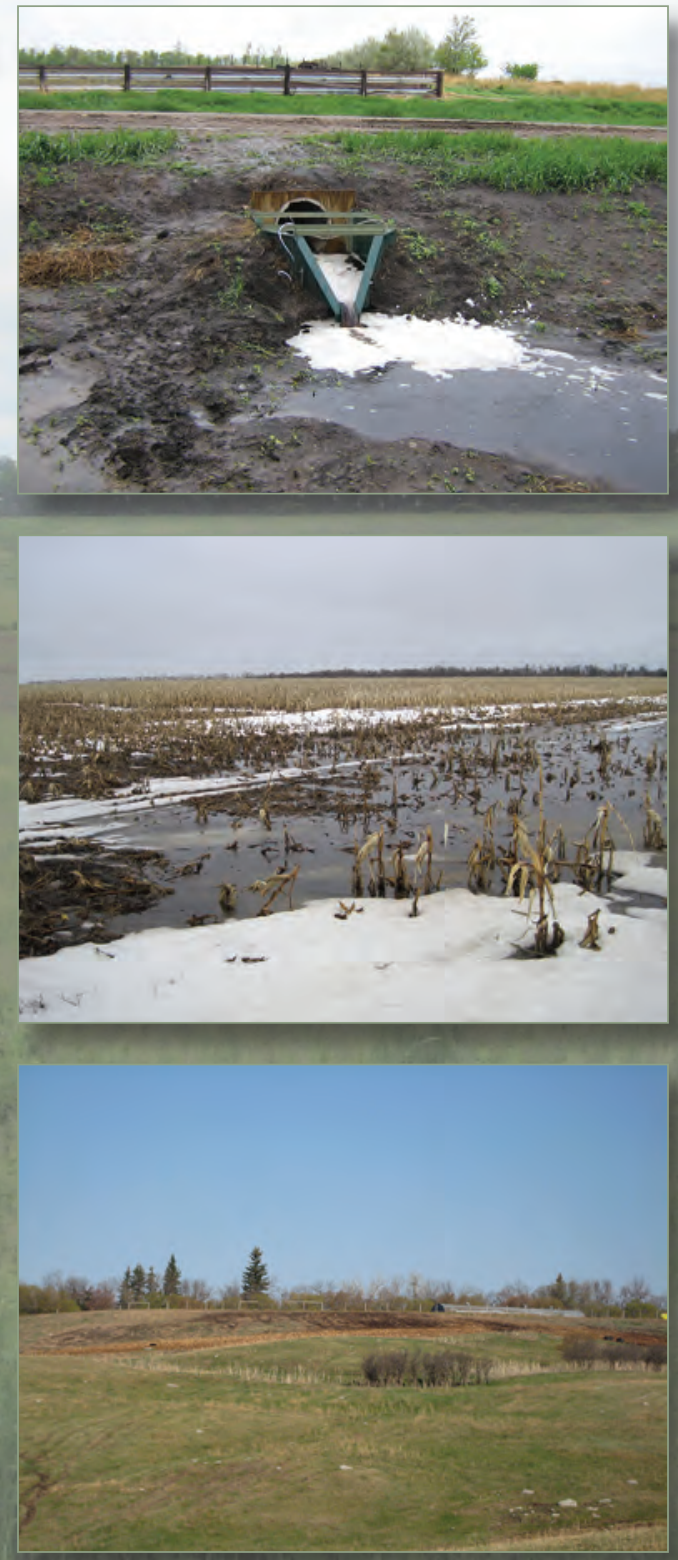

Scientific Investigations Report 2017-5124

U.S. Department of the Interior

U.S. Geological Survey 
Cover. Photographs from top to bottom: Runoff in flume at Underwood farm site U1, June 6, 2008 (photograph by William Damschen, U.S. Geological Survey [USGS]); standing water in field at Embden farm near sites E2 and E3, March 15, 2010 (photograph by William Damschen, USGS); and spring calving area between site D1a and site D2 at Dazey farm, May 15, 2008 (photograph by Kathleen Rowland, USGS). Background photograph: Winter feeding area near site D1b at Dazey farm, July 9, 2009 (photograph by Kathleen Rowland, USGS). 


\section{Runoff and Water-Quality Characteristics of Three Discovery Farms in North Dakota, 2008-16}

By Joel M. Galloway and Rochelle A. Nustad

Prepared in cooperation with North Dakota State University Extension Service

Scientific Investigations Report 2017-5124 


\title{
U.S. Department of the Interior \\ RYAN K. ZINKE, Secretary
}

\section{U.S. Geological Survey William H. Werkheiser, Deputy Director exercising the authority of the Director}

\author{
U.S. Geological Survey, Reston, Virginia: 2017
}

For more information on the USGS - the Federal source for science about the Earth, its natural and living resources, natural hazards, and the environment-visit https://www.usgs.gov or call 1-888-ASK-USGS.

For an overview of USGS information products, including maps, imagery, and publications, visit https://store.usgs.gov.

Any use of trade, firm, or product names is for descriptive purposes only and does not imply endorsement by the U.S. Government.

Although this information product, for the most part, is in the public domain, it also may contain copyrighted materials as noted in the text. Permission to reproduce copyrighted items must be secured from the copyright owner.

Suggested citation:

Galloway, J.M., and Nustad, R.A., 2017, Runoff and water-quality characteristics of three Discovery Farms in North Dakota, 2008-16: U.S. Geological Survey Scientific Investigations Report 2017-5124, 68 p.,

https://doi.org/10.3133/sir20175124.

ISSN 2328-0328 (online) 


\section{Acknowledgments}

The authors gratefully thank the producers that participated in the Discovery Farms program in North Dakota for providing the opportunity to collect valuable information and for sharing information regarding their individual farm operations. 



\section{Contents}

Acknowledgments .....................................................................................................................ii

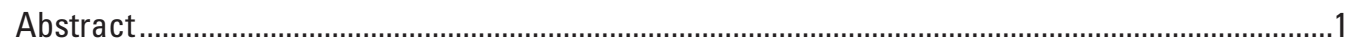

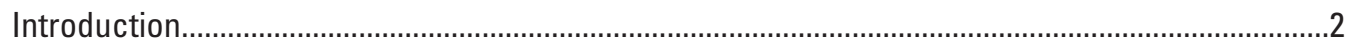





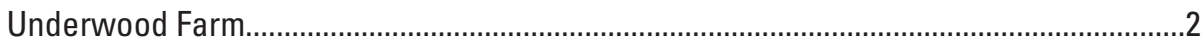

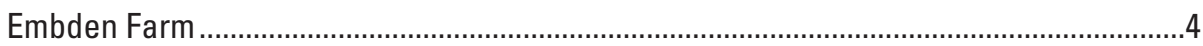

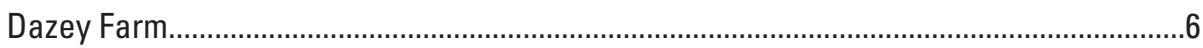

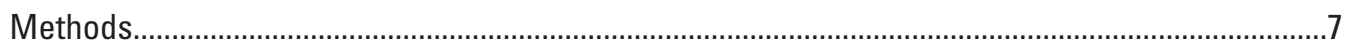

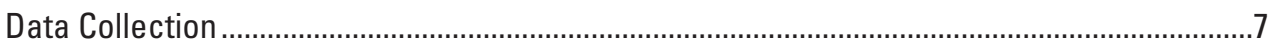

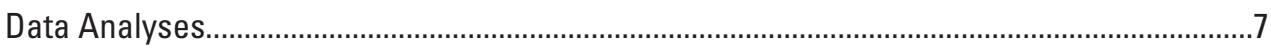

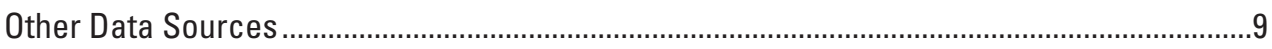

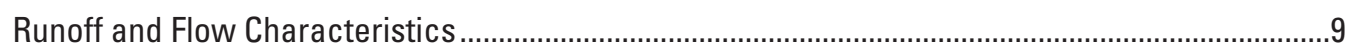

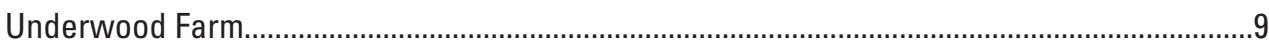

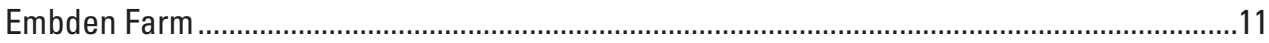

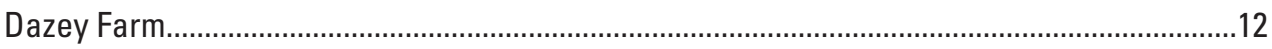

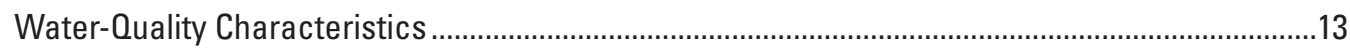

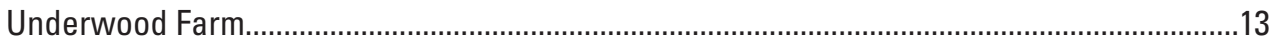

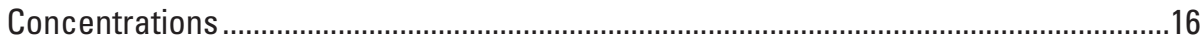

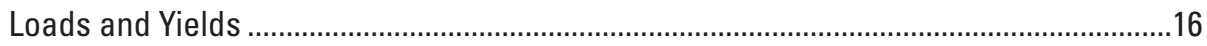

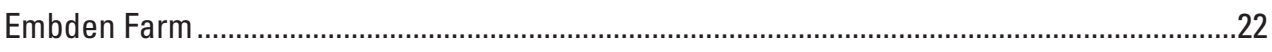

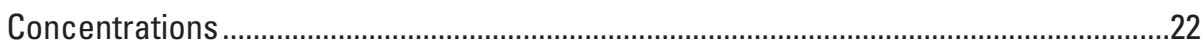

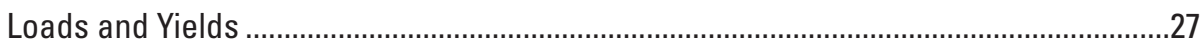

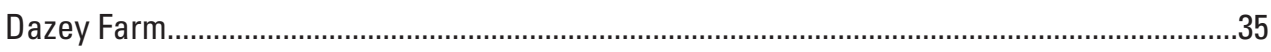

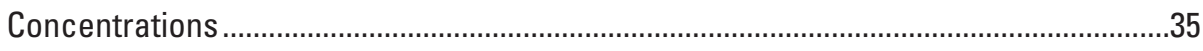

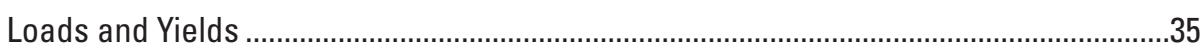

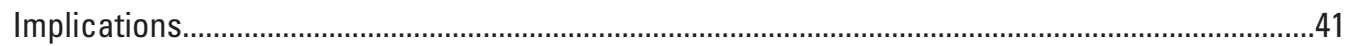

Summary

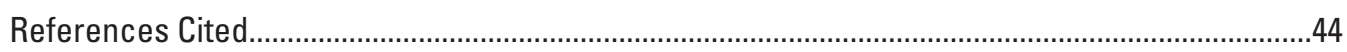

Appendix 1. Additional Runoff and Water-Quality Data for Monitoring Sites at

Three Discovery Farms in North Dakota, 2008-16 ..............................................................4 


\section{Figures}

1. Map showing locations of Discovery Farms sites and other associated sites, North Dakota

2. Map showing location of monitoring sites and study area for Underwood farm in North Dakota

3. Map showing location of monitoring sites and study area for Embden farm in North Dakota

4. Map showing location of monitoring sites and study area for Dazey farm in North Dakota

5. Graph showing monthly precipitation and runoff for monitoring sites at Underwood farm, North Dakota, 2008-16.

6. Graph showing monthly precipitation and runoff for monitoring sites at Embden farm, North Dakota, 2009-16

7. Graph showing monthly precipitation and runoff for monitoring sites at Dazey farms, North Dakota, 2010-15.

8. Graphs showing daily mean flow, daily precipitation, and samples collected at monitoring sites at Underwood farm, North Dakota, 2008-15

9. Graphs showing distribution of constituent concentrations at monitoring sites at Underwood, Embden, and Dazey farms, North Dakota, 2008-16.

10. Graphs showing annual loads estimated for monitoring sites at Underwood farm, North Dakota, 2009-15.

11. Graphs showing mean monthly loads estimated for monitoring sites at Underwood farm, North Dakota, 2009-15

12. Graphs showing annual yields estimated for monitoring sites at Underwood farm, North Dakota, 2009-15.

13. Graphs showing daily mean flow, daily precipitation, and samples collected at monitoring sites at Embden farm, North Dakota, 2009-16.

14. Graphs showing annual loads estimated for monitoring sites at Embden farm, North Dakota, 2010-16

15. Graphs showing monthly loads estimated for monitoring sites at Embden farm, North Dakota, 2010-16.

16. Graphs showing annual yields estimated for monitoring sites at Underwood farm, North Dakota, 2009-15.

17. Graphs showing daily mean flow, daily precipitation, and samples collected at monitoring sites at Dazey farm, North Dakota, 2008-15

18. Graphs showing annual loads estimated for monitoring sites at Dazey farm, North Dakota, 2010-15.

19. Graphs showing monthly loads estimated for monitoring sites at Dazey farm, North Dakota, 2010-15.

20. Graphs showing annual yields estimated for monitoring sites at Dazey farm, North Dakota, 2010-15. 


\section{Tables}

1. Site information for monitoring locations at Discovery Farms, North Dakota

2. Relative percent differences of replicate samples for chloride, nutrient, and suspended-sediment concentrations for samples collected at Discovery Farms, North Dakota, 2008-16

3. Location information for additional precipitation data used for Discovery Farms, North Dakota, 2008-16

4. Annual precipitation, flow volume, and runoff for monitoring sites at Underwood farm, North Dakota, 2008-15.

5. Annual precipitation, flow volume, and runoff for monitoring sites at Embden farm, North Dakota, 2009-16

6. Annual precipitation, flow volume, and runoff for monitoring sites at Dazey farm, North Dakota, 2010-15.

7. Summary of water-quality constituent concentrations for monitoring sites at Underwood farm, North Dakota, 2008-15 14

8. Annual loads and yields for Underwood farm, North Dakota, 2009-15..........................20

9. Fertilizer application and crop information for Underwood farm, North Dakota, 2008-15

10. Loads and yields for selected sites from Galloway and others (2012) and Discovery Farms, North Dakota

11. Summary of water-quality constituent concentrations for monitoring sites at Embden farm, North Dakota, 2009-16

12. Annual loads and yields for Embden farm, North Dakota, 2010-16 .29

13. Estimate of exported and applied nutrients, ratio of exported to applied nutrients and crop type for field 1 at Embden farm, North Dakota, 2010-15

14. Estimate of exported and applied nutrients, ratio of exported to applied nutrients and crop type for field 2 at Embden farm, North Dakota, 2010-15.

15. Summary of water-quality constituent concentrations for monitoring sites at Dazey farm, North Dakota, 2008-15

16. Annual loads and yields for Dazey farm, North Dakota, 2010-15 ...................................38

\section{Appendix Tables}

1-1. Summary of additional water-quality constituent concentrations for selected samples collected at Discovery Farm monitoring sites, North Dakota, 2008-16

1-2. Quality assurance data collected at Discovery Farm monitoring sites, North Dakota, 2008-16

1-3. Monthly loads for monitoring sites at Underwood farm, North Dakota, 2008-15............52

1-4. Monthly loads for monitoring sites at Embden farm, North Dakota, 2009-16 .................58

1-5. Monthly loads for monitoring sites at Dazey farm, North Dakota, 2010-15. 


\section{Conversion Factors}

U.S. customary units to International System of Units

\begin{tabular}{|c|c|c|}
\hline Multiply & By & To obtain \\
\hline \multicolumn{3}{|c|}{ Length } \\
\hline inch (in.) & 2.54 & centimeter $(\mathrm{cm})$ \\
\hline inch (in.) & 25.4 & millimeter $(\mathrm{mm})$ \\
\hline foot $(\mathrm{ft})$ & 0.3048 & $\operatorname{meter}(\mathrm{m})$ \\
\hline mile (mi) & 1.609 & kilometer $(\mathrm{km})$ \\
\hline \multicolumn{3}{|c|}{ Area } \\
\hline square mile $\left(\mathrm{mi}^{2}\right)$ & 2.5900 & square kilometer $\left(\mathrm{km}^{2}\right)$ \\
\hline acre & 0.004047 & square kilometer $\left(\mathrm{km}^{2}\right)$ \\
\hline \multicolumn{3}{|c|}{ Volume } \\
\hline acre-foot (acre-ft) & 1,233 & cubic meter (m3) \\
\hline acre-foot (acre-ft) & 0.001233 & cubic hectometer (hm3) \\
\hline \multicolumn{3}{|c|}{ Flow rate } \\
\hline acre-foot per year (acre-ft/yr) & 1,233 & cubic meter per year $\left(\mathrm{m}^{3} / \mathrm{yr}\right)$ \\
\hline acre-foot per year (acre-ft/yr) & 0.001233 & cubic hectometer per year $\left(\mathrm{hm}^{3} / \mathrm{yr}\right)$ \\
\hline cubic foot per second $\left(\mathrm{ft}^{3} / \mathrm{s}\right)$ & 0.028317 & cubic meter per second $(\mathrm{m} / \mathrm{s})$ \\
\hline \multicolumn{3}{|c|}{ Mass } \\
\hline pound, avoirdupois (lb) & 0.4536 & kilogram $(\mathrm{kg})$ \\
\hline pound, avoirdupois, per year (lb/yr) & 0.4536 & kilograms per year $(\mathrm{kg} / \mathrm{yr})$ \\
\hline $\begin{array}{l}\text { pound, avoirdupois, per year per } \\
\text { acre (lb/yr/acre) }\end{array}$ & 0.4536 & $\begin{array}{l}\text { kilograms per year per square } \\
\text { kilometer }\left(\mathrm{kg} / \mathrm{yr} / \mathrm{km}^{2}\right)\end{array}$ \\
\hline $\begin{array}{l}\text { pound, avoirdupois, per year per } \\
\text { square mile }\left(\mathrm{lb} / \mathrm{yr} / \mathrm{mi}^{2}\right)\end{array}$ & 112.083 & kilograms per year $\left(\mathrm{kg} / \mathrm{yr} / \mathrm{km}^{2}\right)$ \\
\hline tons, short, per year (tons/yr) & 907.185 & kilograms per year $(\mathrm{kg} / \mathrm{yr})$ \\
\hline
\end{tabular}

Temperature in degrees Celsius $\left({ }^{\circ} \mathrm{C}\right)$ may be converted to degrees Fahrenheit $\left({ }^{\circ} \mathrm{F}\right)$ as follows:

$$
{ }^{\circ} \mathrm{F}=\left(1.8 \times{ }^{\circ} \mathrm{C}\right)+32 .
$$

\section{Datum}

Vertical coordinate information is referenced to the North American Vertical Datum of 1988 (NAVD 88).

Horizontal coordinate information is referenced to North American Datum of 1983 (NAD 83).

Elevation, as used in this report, refers to distance above the vertical datum. 


\section{Supplemental Information}

Specific conductance is given in microsiemens per centimeter at 25 degrees Celsius $(\mu \mathrm{S} / \mathrm{cm}$ at $\left.25^{\circ} \mathrm{C}\right)$.

Concentrations of chemical constituents in water are given in milligrams per liter (mg/L).

Application rates are given in pounds per year per acre (lb/yr/acre).

\section{Abbreviations}

NWIS National Water Information System

SPARROW SPAtially Referenced Regressions On Watershed attributes

[U.S. Geological Survey model]

USGS U.S. Geological Survey 



\title{
Runoff and Water-Quality Characteristics of Three Discovery Farms in North Dakota, 2008-16
}

\author{
By Joel M. Galloway and Rochelle A. Nustad
}

\section{Abstract}

Agricultural producers in North Dakota are aware of concerns about degrading water quality, and many of the producers are interested in implementing conservation practices to reduce the export of nutrients from their farms. Producers often implement conservation practices without knowledge of the water quality of the runoff from their farm or if conservation practices they may implement have any effect on water quality. In response to this lack of information, the U.S. Geological Survey, in cooperation with North Dakota State University Extension Service and in coordination with an advisory group consisting of State agencies, agricultural producers, and commodity groups, implemented a monitoring study as part of a Discovery Farms program in North Dakota in 2007. Three data-collection sites were established at each of three farms near Underwood, Embden, and Dazey, North Dakota. The purpose of this report is to describe runoff and water-quality characteristics using data collected at the three Discovery Farms during 2008-16. Runoff and water-quality data were used to help describe the implications of agricultural conservation practices on runoff and water-quality patterns.

Runoff characteristics of monitoring sites at the three farms were determined by measuring flow volume and precipitation. Runoff at the Underwood farm monitoring sites generally was controlled by precipitation in the area, antecedent soil moisture conditions, and, after 2012, possibly by the diversion ditch constructed by the producer. Most of the annual runoff was in March and April each year during spring snowmelt. Runoff characteristics at the Embden farm are complex because of the mix of surface runoff and flow through two separate drainage tile systems. Annual flow volumes for the drainage tiles sites (sites E2 and E3) were several orders of magnitude greater than measured at the surface water site E1. Site E1 generally only had runoff briefly in March and April during spring snowmelt and during only a few large rain events throughout 2009-16. Flow was somewhat continuous at sites E2 and E3 throughout the year during years of increased precipitation, such as in 2010 and 2011. At Dazey farm, annual flow volumes at the most downstream site D3 for 2010-15 ranged from 88 acre-feet (2012) to 12,060 acre-feet (2010). The largest monthly runoff volumes at D1 (most upstream site; combination of data from site D1a [original site] and site D1b [relocated site]) and D3 were in March and April during spring snowmelt runoff and rain events.

At Underwood farm, total ammonia and total phosphorus had the highest concentrations at the most upstream site (U1) and decreased sequentially at sites U2 and U3 downstream. Total ammonia and total phosphorus concentrations at the sites for Underwood farm also generally were higher than measured at sites for the Dazey and Embden farms. At Embden farm, nitrate plus nitrite concentrations were lowest at site E1 (surface-water site) and highest at sites E2 and E3 (drainage tile sites). Nitrate plus nitrite concentrations at sites E2 and E3 also were the highest among all the sites at all three farms. Median total nitrate plus nitrite concentrations for sites E1, E2, and E3 were $0.22,13$, and 10 milligrams per liter as nitrogen, respectively. Nutrient concentrations generally were greater at site D1 (most upstream site) compared to site D3 (most downstream site) at Dazey farm. Higher concentrations at site D1, which is farther upstream and closer to potential sources of nutrients, compared to lower concentrations at site D3, which is farther downstream and receives more runoff, indicates that dilution may be the reason concentrations decrease downstream.

Annual loads for chloride at all three Underwood sites were the greatest in 2011 and the least in 2012, which coincided with years of the greatest and least annual flow volume, respectively. Total ammonia had a similar pattern at the three sites. Nitrate plus nitrite loads displayed a different pattern than chloride and total ammonia, indicating possible different sources. Chloride, total ammonia, total phosphorus, and suspended sediment were transported past site U1 mostly in March and the least from July through October. Monthly nitrate plus nitrite loads had a different pattern than the other constituents, indicating other possible sources such as fertilizer application in the surrounding cropland.

Annual loads for Embden farm were considerably greater at sites E2 and E3 compared to site E1. Annual yields for all constituents also were substantially greater at sites E2 and E3 compared to site E1, mainly because of a combination of higher flow volumes and small contributing drainage areas at sites E2 and E3 compared to site E1.

The greatest annual loads at Dazey farm site D3 for chloride, nitrate plus nitrite, and suspended sediment were in 2010 and 2011, and zero loads were estimated for 2012 because no 
flow was measured at the site. Mean monthly loads generally were greatest for most constituents in March and April at sites D1 and D3 except for suspended sediment that had the greatest monthly loads in May.

To mitigate runoff and water-quality effects of their operations, the producers implemented various agricultural conservation practices before and during the Discovery Farms monitoring. Even though it was difficult to quantify the effects of the agricultural conservation practices implemented at the farms, the data collected from the Discovery Farms program provided a better understanding of some of the variables that affect runoff and water quality.

\section{Introduction}

Of the 45.3 million acres of land in North Dakota, 39.4 million acres, or 87 percent of North Dakota's land area, are used for agriculture (North Dakota, 2017). According to the U.S. Environmental Protection Agency (2017a), agricultural nonpoint source pollution is the leading source of waterquality effects on rivers and streams. In 2016, 33.9 percent of North Dakota rivers and streams had water quality that did not support the designated use for fish and other aquatic biota (U.S. Environmental Protection Agency, 2017b). Much work has been done to improve water quality, including implementing various agricultural conservation practices on cultivated cropland. On a regional scale, in the Upper Mississippi River Basin, application of the U.S. Geological Survey (USGS) SPAtially Referenced Regressions On Watershed attributes (SPARROW) model has indicated that conservation practices have had a statistically significant effect on reducing nitrogen and a lesser effect on phosphorus loads (Garcia and others, 2016). Within North Dakota, in the Souris-Red-Rainy Basin, recent research by the U.S. Department of Agriculture (2014) indicated that the Conservation Effects Assessment Project has improved water quality. Agricultural producers in North Dakota are aware of concerns about degrading water quality, and many of the producers are interested in implementing conservation practices to reduce the export of nutrients from their farms - not only because it reduces the effect on receiving waters, but also because it is beneficial to the producer to retain nutrients. Producers often implement conservation practices without knowledge of the water quality of the runoff from their farm or if conservation practices they may implement have any effect on water quality. In response to this lack of information, the USGS, in cooperation with North Dakota State University Extension Service and in coordination with an advisory group consisting of State agencies, agricultural producers, and commodity groups, implemented a monitoring study as part of a Discovery Farms program in North Dakota in 2007. Several States have developed a Discovery Farms program, and the intent of the program is to collect and analyze water-quality information from agricultural lands and livestock feeding areas and to document the effectiveness of producer-driven solutions at minimizing negative effects on water quality (University of Wisconsin, 2017; University of Arkansas, 2017; Minnesota Department of Agriculture, 2017; North Dakota State University, 2009). As part of the Discovery Farms program, hydrologic and water-quality data were collected at three Discovery Farms in North Dakota (fig. 1) during 2008-16.

\section{Purpose and Scope}

The purpose of this report is to describe the runoff and water-quality characteristics using data collected at three Discovery Farms in North Dakota (fig. 1) during 2008-16. Runoff and water-quality data were used to help describe the implications of agricultural conservation practices on runoff and water-quality patterns.

\section{Description of the Study Areas}

Discovery Farms in North Dakota were established in late 2007 near Underwood, North Dakota, in McLean County (hereafter referred to as "Underwood farm"); in late 2008 near Embden, N. Dak., in Cass County (hereafter referred to as "Embden farm"); and in early 2008 near Dazey, N. Dak., in Barnes County (hereafter referred to as "Dazey farm") (fig. 1). Each farm had three data-collection sites.

\section{Underwood Farm}

Underwood farm is a crop and cattle operation about 8 miles (mi) west of Underwood, N. Dak., and about $3 \mathrm{mi}$ east of the Missouri River (fig. 1). A feedlot is at the southeast quadrant of the farm, and cropland makes up most of the surrounding area (fig. 2). Surrounding cropland generally was planted with a mix of mostly spring wheat, but some fields periodically were planted with corn, soybeans, barley, and sunflowers during the period of runoff and water-quality data collection at this site (2008-15) (Joao Paulo Flores, North Dakota State University Extension Service, written commun., 2017). Beef cows are placed in the feedlot during the winter months and remain there through the early spring until they are ready for calving. Once the cows are ready for calving, they are moved to an offsite pasture (not shown) with their calves during the summer months and are kept together until weaning in early fall (Nustad and others, 2015). Weaned calves also are placed in the feedlot in the fall and remain there until late winter before being moved to finishing lots in other parts of the State. Most of the pens in the feedlot are empty during the summer months. Manure accumulation from the winter months is scraped and piled in the pens after the cows and calves are sent to pasture. Manure is stored in the empty pens until late summer when it is spread on surrounding cropland to be used as a crop fertilizer.

Runoff from the farm and feedlot enters a waterway that generally trends from north to south (fig. 2). Runoff from the 


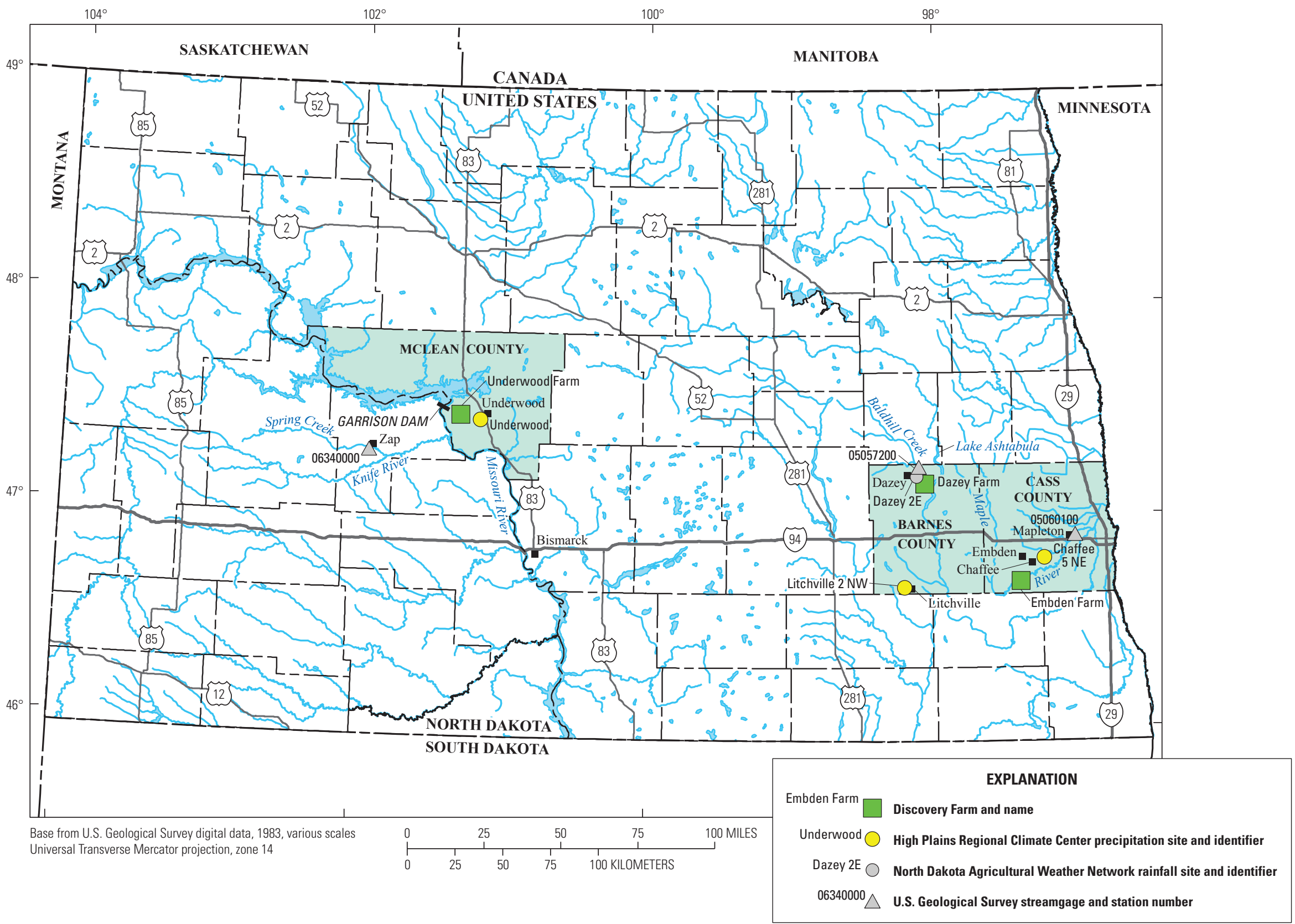

Figure 1. Locations of Discovery Farms sites and other associated sites, North Dakota. 
Table 1. Site information for monitoring locations at Discovery Farms, North Dakota.

[USGS, U.S. Geological Survey; SW, surface water; DT, drainage tile]

\begin{tabular}{|c|c|c|c|c|c|}
\hline Station number & USGS station name & $\begin{array}{l}\text { Abbreviated } \\
\text { name }\end{array}$ & $\begin{array}{c}\text { Drainage area, } \\
\text { acres }\end{array}$ & Site type & Period of record \\
\hline \multicolumn{6}{|c|}{ Underwood Farm, McLean County } \\
\hline 472731101175500 & $\begin{array}{l}\text { Discovery Farms Waterway Site } 1 \text { near } \\
\text { Underwood, North Dakota }\end{array}$ & U1 & 87 & SW & May 2008-October 2015. \\
\hline 472727101175000 & $\begin{array}{l}\text { Discovery Farms Waterway Site } 2 \text { near } \\
\text { Underwood, North Dakota }\end{array}$ & $\mathrm{U} 2 \mathrm{a}$ & 1,918 & SW & June 2008-October 2014. \\
\hline 472709101175100 & $\begin{array}{l}\text { Discovery Farms Waterway Site } 3 \text { near } \\
\text { Underwood, North Dakota }\end{array}$ & U3 & 1,976 & SW & June 2008-October 2015. \\
\hline \multicolumn{6}{|c|}{ Embden Farm, Cass County } \\
\hline 464115097255000 & $\begin{array}{l}\text { Discovery Farms Waterway Site } 1 \text { near } \\
\text { Embden, North Dakota }\end{array}$ & $\mathrm{E} 1^{\mathrm{a}}$ & 164 & SW & April 2009-October 2016. \\
\hline 464115097254700 & $\begin{array}{l}\text { Discovery Farms Waterway Site } 2 \text { near } \\
\text { Embden, North Dakota }\end{array}$ & E2 & $66^{\mathrm{b}}$ & DT & June 2009-October 2016. \\
\hline 464114097260900 & $\begin{array}{l}\text { Discovery Farms Waterway Site } 3 \text { near } \\
\text { Embden,North Dakota }\end{array}$ & E3 & $70^{\mathrm{b}}$ & DT & April 2009-October 2016. \\
\hline \multicolumn{6}{|c|}{ Dazey Farm, Barnes County } \\
\hline 470856098050600 & $\begin{array}{l}\text { Discovery Farms Waterway Site } 1 \text { near } \\
\text { Dazey, North Dakota }\end{array}$ & $\mathrm{D} 1^{\mathrm{a}}$ & 30 & SW & October 2008-October 2012. \\
\hline 470856098050600 & $\begin{array}{l}\text { Discovery Farms Waterway Site } 1 \text { near } \\
\text { Dazey, North Dakota }\end{array}$ & $\mathrm{D} 1^{\mathrm{b}}$ & 24 & SW & October 2012-October 2015. \\
\hline 470856098045800 & $\begin{array}{l}\text { Discovery Farms Waterway Site } 2 \text { near } \\
\text { Dazey, North Dakota }\end{array}$ & $\mathrm{D} 2$ & 80 & SW & Mar 2009-April 2011. \\
\hline 470850098044500 & $\begin{array}{l}\text { Discovery Farms Waterway Site } 3 \text { near } \\
\text { Dazey, North Dakota }\end{array}$ & D3 & 341 & SW & April 2009-October 2015. \\
\hline
\end{tabular}

aPrecipitation gage installed at site.

brainage area is an estimate based on configuration of drainage tile.

farm contributes to a small drainage basin that flows into the Missouri River. Three data-collection sites were along the waterway south of the farm (fig. 2). The drainage area for each of the sites ranges from 87 to 1,976 acres (Nustad and others, 2015) (table 1).

The feedlot is managed by the producer to reduce effects to downstream receiving water bodies, and in response to data collected from the Discovery Farms program, a conservation practice was implemented during the program. Data collected during the first 2 years (2008-10) indicated large loads of chloride, nutrients, and sediment were coming from the flow of water across the feedlot into the waterway, especially during spring months (Nustad and others, 2015). In response to these data, the producer constructed a diversion ditch in 2012 to divert runoff around the feedlot to reduce the transport of material from the feedlot (fig. 2).

\section{Embden Farm}

Embden farm is a crop and cattle production operation about 8 mi south of Embden, N. Dak., and about 1 mi north of the Maple River (fig. 1). Although Embden farm has a cattle operation, the data collection sites are in an area only affected by runoff from cropland (fig. 3). The owners of the Embden farm have been implementing conservation practices such as crop rotation, no-till, split-applied fertilizer application, and cover crops for several years before the Discovery Farms program and continue to implement these practices.

Crops grown on the farm include corn, soybeans, wheat, and alfalfa. The soils vary from well drained to somewhat poorly drained soils, and runoff is generally slow (Nustad and others, 2015). Subsurface drainage tiles were installed in an agricultural field at the farm in 2009 , and water from the 


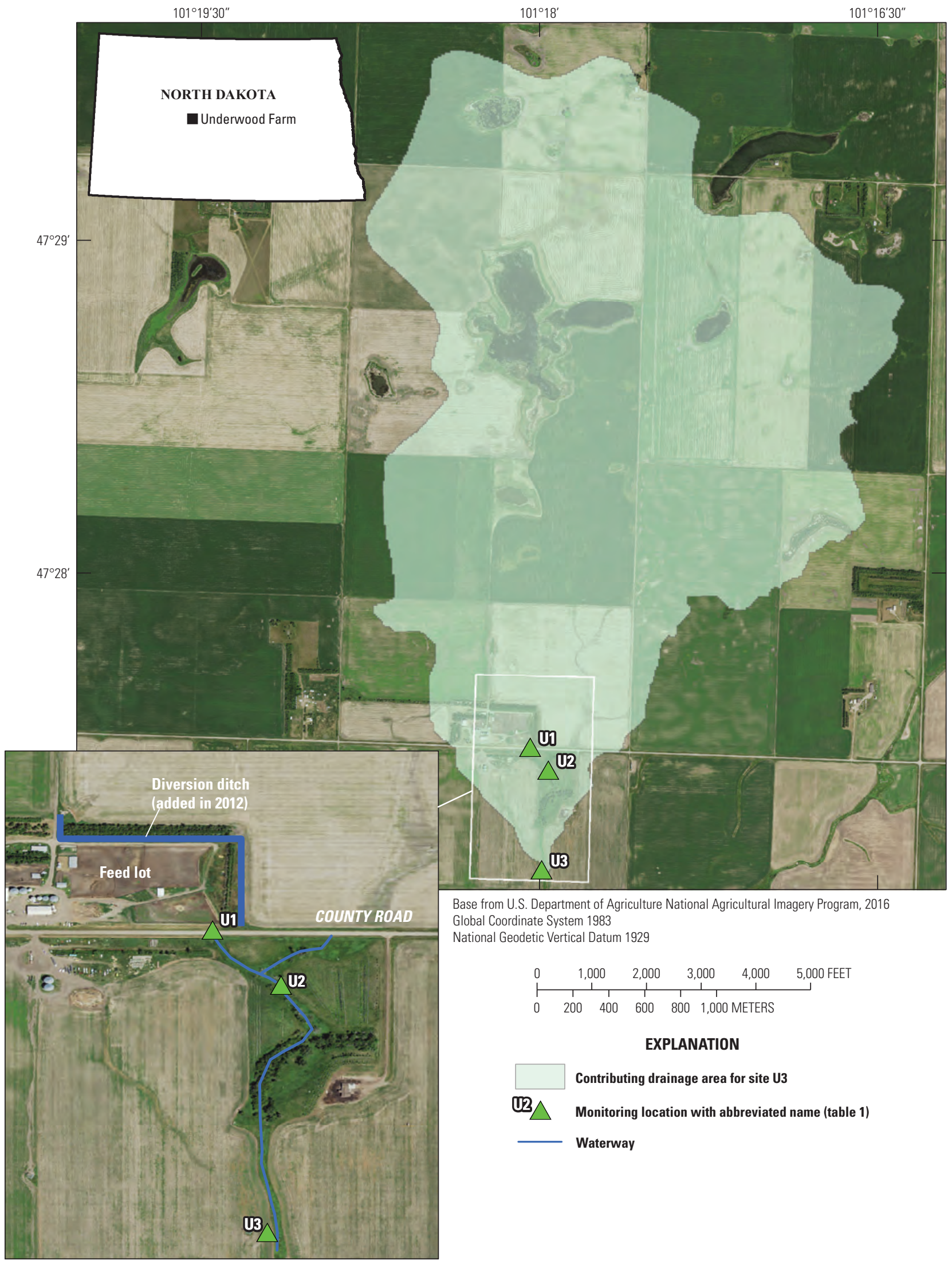

Figure 2. Location of monitoring sites and study area for Underwood farm in North Dakota. 
drains can flow into the Maple River (fig. 3). The field being monitored has two separate subsurface drainage tile systems that drain the east (field 1) and west (field 2) halves of the field (fig. 3). Historically, the east and west fields have been farmed as one unit; therefore, the two subsurface drainage tile systems provide a paired drainage system for comparative analyses. On the east field (field 1), most of the field surface drainage exits in the southeast corner for the east subsurface drainage system and is monitored at site E1. The drainage tile outlet for the east field is managed by a flume and is monitored at site E2. The drainage tile outlet for the west field (field 2) is managed by a flume inserted into the drainage tile underground and is monitored at site E3. Drainage areas based on surface topography are provided in table 1, but because of fluctuating water-table elevations the exact land acreage drained by the subsurface drainage sites could not be determined for sites E2 and E3 (Nustad and others, 2015).

\section{Dazey Farm}

Dazey farm is a crop and cattle operation about $6 \mathrm{mi}$ east and 2 mi south of Dazey, N. Dak., and 3 mi west of Lake Ashtabula (fig. 1). Spurred by the initiation of the Discovery Farms program, but before data collection, the producer implemented changes in their farming operation to reduce their effect on downstream water quality. The feedlot was relocated from the east side of the tree row, near the farmhouse, to the west side of the tree row (fig. 4). The new location of the feedlot is on a flat area, farther upslope from the natural drainage,



Figure 3. Location of monitoring sites and study area for Embden farm in North Dakota. 
and runoff is filtered by a tree row and vegetation before flowing into the waterway in the pasture. Also before data collection, the feeding area was expanded during the winter months, and cattle graze on crop residue.

The feedlot and winter cattle feeding area are to the west of the farmhouse, and cropland makes up most of the surrounding area (fig. 4). After being brought in from pasture in the fall, the beef cows are wintered on the cattle feeding area, which is primarily cropland. The cattle graze on crop residue and, if supplemented with stored feed, the feeding areas are randomly located in the cropland area to decrease the amount of concentrated feeding areas (Nustad and others, 2015). Feeding area runoff from the cropland, which can flow rapidly, travels mostly eastward along a waterway into Baldhill Creek (fig. 4) and then into Lake Ashtabula (about $3 \mathrm{mi}$ downstream, fig. 1). The waterway traverses through a pasture, which serves as a calving area for the beef cows in early spring (fig. 4). Three data-collection sites were established along the waterway and were operated from 2009 to 2015, although one site (site D2) was only operated from 2009 to 2011 because it was destroyed by excess runoff and sedimentation in April 2011. The most upstream site (site D1a) was moved about 300 feet (ft) upstream in the drainage to site D1b in 2011 because heavy sedimentation made collecting good quality flow data difficult. The most downstream site (D3) receives runoff from the cattle feeding area and runoff from cropland on neighboring farms. The drainage area for the three original sites ranges from 30 to 341 acres (Nustad and others, 2015), and the drainage area of site D1b is 24 acres (table 1). Crop information was not available for the farm.

\section{Methods}

Discharge, rainfall, and water-quality data were collected at Underwood, Embden, and Dazey farms. Flow volume, derived from discharge measurements, and concentration data were summarized in graphical and tabular form, and the data were used to estimate constituent loads and yields for each site. Data that were not available at the farm sites but were needed for further analyses were obtained from other sources, such as precipitation data and loads and yields data for larger streams to compare to the monitoring sites.

\section{Data Collection}

Each monitoring site contained a refrigerated, automated water sampler that held 24 1-liter sample bottles, a datalogger, a bubble-gage system (Sauer and Turnipseed, 2010), and a flume. At Embden farm, an extra-large 60-degree $V$ trapezoidal flume was installed underground at sites E2 and E3 to capture runoff from subsurface drainage tiles. A tipping-bucket rain gage was installed at one site on each farm. Additional location information for the farms is presented in table 1 , and information on the instrumentation and monitoring methods is described in Nustad and others (2015).

Samples were collected by automatic samplers and manually at all the sites. Samples were analyzed for several constituents including chloride, nutrients (ammonia, nitrate plus nitrite, and phosphorus), total suspended solids, and suspended sediment. A subset of the samples was analyzed for additional constituents such as major ions, iron, and manganese (appendix table 1-1). All laboratory analyses were completed by the North Dakota Department of Health Laboratory in Bismarck, N. Dak., following procedures described in Clesceri and others (1999) or the U.S. Environmental Protection Agency (2017c). All water-quality data for these sites are stored and are available from the USGS National Water Information System (NWIS) database (U.S. Geological Survey, 2017).

Quality-assurance samples (blank and replicate waterquality samples) also were collected at the sites to determine adequate reproducibility and proper cleaning conditions of equipment. In total, 4 blank samples and 38 replicate samples were collected at sites. Field blank samples were collected from the automatic sampler intake lines and had some detections that were greater than the laboratory reporting levels, but well below environmental sample concentrations, indicating that the flushing or cleaning of the line between samples was adequate to prevent cross contamination of samples. The analytical variability of replicate samples for constituents was assessed using relative percent difference (calculated as the absolute difference in concentration divided by the mean concentration multiplied by 100 for the environmental/ replicate sample pair). Mean relative percent differences for chloride, total ammonia, and total phosphorus were 4.6, 9.5, and 2.1, respectively (table 2), indicating satisfactory quality assurance on these constituents. Variability for total nitrate plus nitrite and suspended sediment was higher with mean relative percent differences of 14.9 and 18.3, respectively (table 2). Quality-assurance sample data were stored in the USGS NWIS database (U.S. Geological Survey, 2017) and are presented in appendix table 1-2.

\section{Data Analyses}

Discharge data are described in this report in terms of flow volume and runoff at each site. Daily mean discharge values were computed for each site using techniques described in Sauer and Turnipseed (2010). Annual and monthly flow volumes were computed by converting the daily mean discharge values (in cubic feet per second) into daily flow volumes by multiplying the value by time and converting the volume to acre-feet, then accumulating the daily flow volumes for each month and year. Generally, many of the sites only had flow in March through November, with the exception of the two drainage tile sites at Embden farm, which had flow throughout the winter months in 2010 and 2011. Annual and monthly runoff volumes were computed by dividing the annual and monthly flow volumes by the respective 


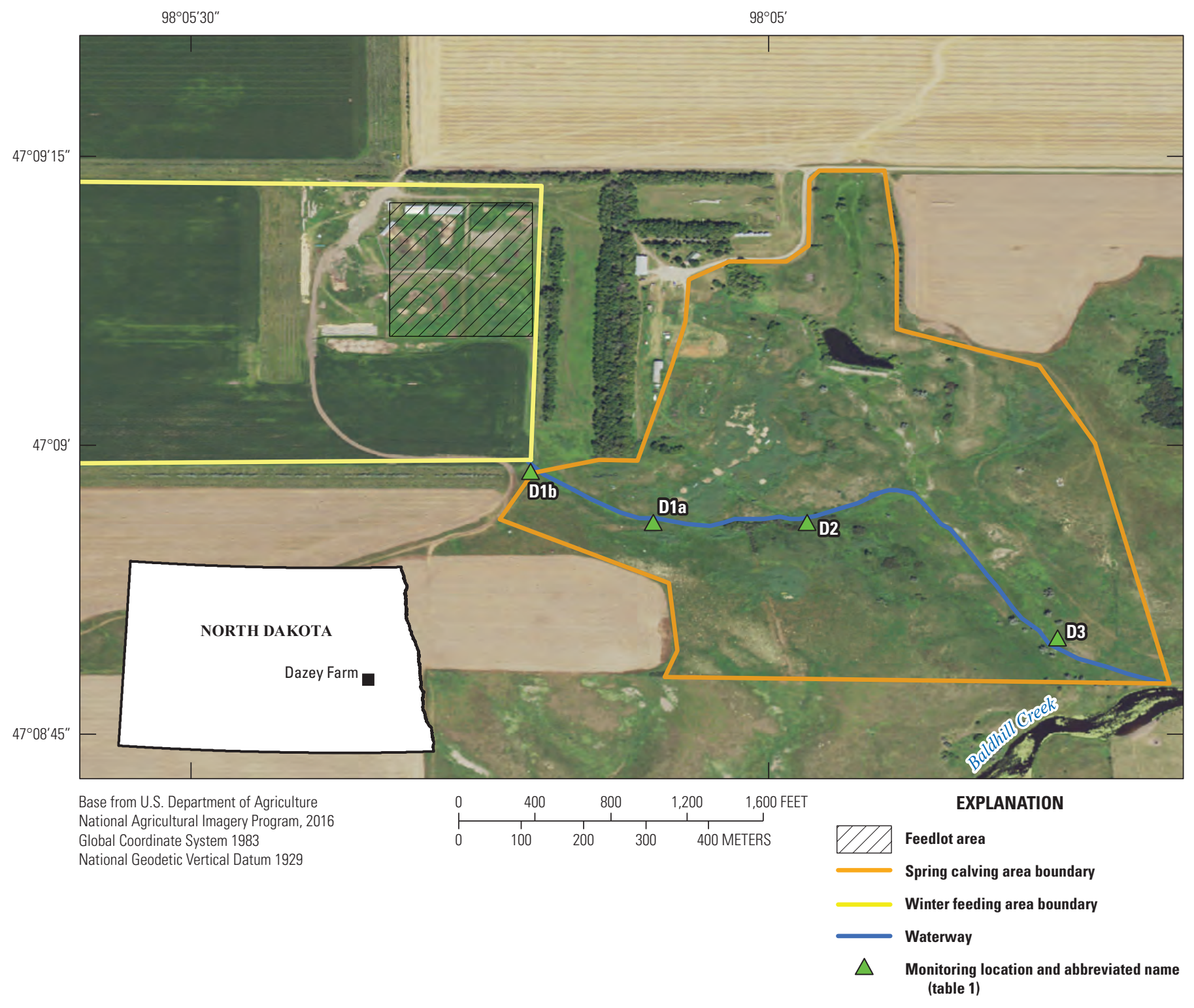

Figure 4. Location of monitoring sites and study area for Dazey farm in North Dakota.

Table 2. Relative percent differences of replicate samples for chloride, nutrient, and suspended-sediment concentrations for samples collected at Discovery Farms, North Dakota, 2008-16.

[Calculation of percent difference is: $\left|\left(x_{1}-x_{2}\right) /\left(x_{1}-x_{2}\right) / 2\right| \times 100$, where $x_{1}$ is environmental sample, $x_{2}$ is sequential replicate]

\begin{tabular}{lcc}
\hline \multicolumn{1}{c}{ Constituent } & $\begin{array}{c}\text { Number of } \\
\text { samples }\end{array}$ & $\begin{array}{c}\text { Mean relative percent } \\
\text { difference }\end{array}$ \\
\hline Chloride & 32 & 4.6 \\
Total ammonia & 25 & 9.5 \\
Total nitrate plus & 34 & 14.9 \\
$\quad$ nitrite & & \\
Total phosphorus & 29 & 2.1 \\
Suspended sediment & 12 & 18.3 \\
\hline
\end{tabular}

contributing drainage areas estimated for each site and multiplying by a unit conversion factor. Flow volumes and runoff were compared to precipitation data for each farm in graphical and tabular form.

Concentration data were presented for selected constituents using boxplot graphs to show the distribution of data for each constituent at each site and summary statistics in tables. Data not described in the report are summarized in appendix table 1-1. All concentration data from samples collected for Discovery Farms are stored in the USGS NWIS database (U.S. Geological Survey, 2017).

Concentration and discharge data were used to compute constituent loads and yields for each of the sites. Daily loads were computed for sites using estimated daily mean values of constituent concentration and discharge data for the periods 
of record from selected Discovery Farm sites. The daily loads were summed into monthly and annual loads for presentation in this report. To compare sites with different contributing drainage areas, the annual loads were divided by the contributing drainage areas for each site to produce annual yields in pounds per year per acre. Computation of loads is described in further detail in Nustad and others (2015).

\section{Other Data Sources}

Precipitation data for winter months (November-March) were obtained from other sites near the respective farms (High Plains Regional Climate Center, 2017) (fig. 1; table 3). Data were obtained for the winter months from other sources because snowfall was not measured at the sites. Rainfall data were supplemented with data from other sites during periods of missing data at the Discovery Farm sites. At Underwood farm, the rainfall gage at $\mathrm{U} 2$ did not function properly for 2013-15, so a site near Underwood, N. Dak., was used for monthly precipitation values for that period (fig. 1; High Plains Regional Climate Center, 2017). At Dazey farm, precipitation data from a nearby North Dakota Agricultural Weather Network site were used for rainfall data because of periods of missing rainfall data at site D1 (fig. 1; North Dakota Agricultural Weather Network, 2017).

Estimated load and yield data were obtained for selected sites from Galloway and others (2012) for comparison to the loads and yields for the Discovery Farm sites. Loads and yields in Galloway and others (2012) were computed using 30 years of data for individual sites and normalized to a single year. Normalized annual loads were presented in tons per year and were converted to pounds per year for comparison to the Discovery Farm sites. Likewise, normalized annual yields were presented in Galloway and others (2012) in units of pounds per year per square mile and were converted to pounds per year per acre for comparison.
Crop and fertilizer application data were provided by the producers at Underwood and Embden farm to help understand runoff and water quality at the sites. Fertilizer application data were estimated only for the area of the farms operated by the producers, and several of the sites had contributing drainage much larger than the area where data were available. Fertilizer was applied at different rates, using different fertilizer types, and at different times of the year at each farm. Individual applications were documented mostly as handwritten notes and, where data were available, were summarized and presented as total annual nitrogen and phosphorus, in pounds applied to fields.

\section{Runoff and Flow Characteristics}

Runoff characteristics of monitoring sites at the three farms were determined by measuring flow volume and precipitation. A wide range of hydrologic conditions were measured at all three farms during 2008-16. At all the farm monitoring sites, the greatest annual precipitation (rainfall and snowfall) was measured in 2010, and the least annual rainfall was measured in 2012 (tables 4-6). At Underwood farm, annual precipitation ranged from 12.6 to 24.8 inches (in.) (2008-15), at Embden farm the annual precipitation ranged from 13.8 to 31.0 in. (2009-16), and at Dazey farm the annual precipitation ranged from 9.4 to 20.6 in. (2010-15) (tables 4-6, respectively).

\section{Underwood Farm}

Runoff at the Underwood farm monitoring sites generally was controlled by precipitation in the area, antecedent soil moisture conditions, and, after 2012, possibly by the diversion ditch constructed by the producer (fig. 2). Flow volume was highest at the most downstream site U3; annual flow volumes

Table 3. Location information for additional precipitation data used for Discovery Farms, North Dakota, 2008-16.

[NDAWN, North Dakota Agricultural Weather Network; HPRCC, High Plains Regional Climate Center]

\begin{tabular}{|c|c|c|c|c|c|c|c|}
\hline $\begin{array}{c}\text { Data } \\
\text { source }\end{array}$ & $\begin{array}{c}\text { Station name } \\
\text { (fig. 1) }\end{array}$ & $\begin{array}{l}\text { Station } \\
\text { number }\end{array}$ & Latitude & Longitude & Data type & $\begin{array}{c}\text { Farm where data } \\
\text { were used }\end{array}$ & Period that data was used \\
\hline NDAWN & Dazey 2E & 19 & 47.183 & -98.138 & Rainfall & Dazey farm & April 2010-October 2015. \\
\hline HPRCC & Chaffee $5 \mathrm{NE}$ & CHFN8 & 46.79583 & -97.26862 & $\begin{array}{l}\text { Precipitation } \\
\text { (rainfall and } \\
\text { snowfall) }\end{array}$ & Embden farm & November-March 2008-2016. \\
\hline HPRCC & Litchville $2 \mathrm{NW}$ & LTHN8 & 46.66111 & -98.22667 & $\begin{array}{l}\text { Precipitation } \\
\text { (rainfall and } \\
\text { snowfall) }\end{array}$ & Dazey farm & November-March 2009-2015. \\
\hline
\end{tabular}


Table 4. Annual precipitation, flow volume, and runoff for monitoring sites at Underwood farm, North Dakota, $2008-15$.

$[--$, not available, $<$, less than $]$

\begin{tabular}{|c|c|c|c|c|c|c|c|c|c|c|}
\hline \multirow[b]{2}{*}{ Year } & \multirow[b]{2}{*}{$\begin{array}{c}\text { Total annual } \\
\text { precipitation, } \\
\text { in inches }{ }^{1}\end{array}$} & \multicolumn{3}{|c|}{ U1 } & \multicolumn{3}{|c|}{ U2 } & \multicolumn{3}{|c|}{ U3 } \\
\hline & & $\begin{array}{c}\text { Flow } \\
\text { volume, in } \\
\text { acre-feet }\end{array}$ & $\begin{array}{l}\text { Runoff, } \\
\text { in inches }\end{array}$ & $\begin{array}{c}\text { Runoff as a } \\
\text { percentage } \\
\text { of rainfall }\end{array}$ & $\begin{array}{c}\text { Flow } \\
\text { volume, in } \\
\text { acre-feet }\end{array}$ & $\begin{array}{l}\text { Runoff, } \\
\text { in inches }\end{array}$ & $\begin{array}{c}\text { Runoff as a } \\
\text { percentage } \\
\text { of rainfall }\end{array}$ & $\begin{array}{c}\text { Flow } \\
\text { volume, in } \\
\text { acre-feet }\end{array}$ & $\begin{array}{l}\text { Runoff, } \\
\text { in inches }\end{array}$ & $\begin{array}{c}\text { Runoff as a } \\
\text { percentage } \\
\text { of rainfall }\end{array}$ \\
\hline 2008 & 16.7 & 128 & 0.12 & 0.7 & 569 & 0.02 & 0.1 & 401 & 0.02 & 0.1 \\
\hline 2009 & 18.2 & 3,720 & 3.56 & 19.5 & 12,500 & 0.54 & 3.0 & 14,400 & 0.61 & 3.3 \\
\hline 2010 & 24.8 & 3,150 & 3.02 & 12.2 & 7,960 & 0.35 & 1.4 & 12,200 & 0.51 & 2.1 \\
\hline 2012 & 12.6 & 347 & 0.33 & 2.6 & 111 & $<0.01$ & $<0.1$ & 136 & 0.01 & $<0.1$ \\
\hline $2013^{2}$ & 20.1 & 1,950 & 1.87 & 9.3 & 2,070 & 0.09 & 0.4 & 2,290 & 0.10 & 0.5 \\
\hline $2014^{2}$ & 20.1 & 1,460 & 1.40 & 7.0 & 8,960 & 0.39 & 1.9 & 11,200 & 0.47 & 2.3 \\
\hline $2015^{2}$ & 17.9 & 1,310 & 1.26 & 7.0 & -- & -- & -- & 4,950 & 0.21 & 1.2 \\
\hline
\end{tabular}

'Data from April through October are from site U2, data for November-March is from a High Plains Regional Climate Center site near Underwood, North Dakota.

${ }^{2}$ All data from a High Plains Regional Climate site near Underwood, North Dakota.

Table 5. Annual precipitation, flow volume, and runoff for monitoring sites at Embden farm, North Dakota, $2009-16$.

$[<$, less than $]$

\begin{tabular}{|c|c|c|c|c|c|c|c|c|c|c|}
\hline \multirow[b]{2}{*}{ Year } & \multirow[b]{2}{*}{$\begin{array}{c}\text { Total annual } \\
\text { precipitation, } \\
\text { in inches }^{1}\end{array}$} & \multicolumn{3}{|c|}{ E1 } & \multicolumn{3}{|c|}{ E2 } & \multicolumn{3}{|c|}{ E3 } \\
\hline & & $\begin{array}{c}\text { Flow } \\
\text { volume, in } \\
\text { acre-feet }\end{array}$ & $\begin{array}{c}\text { Runoff, } \\
\text { in inches }\end{array}$ & $\begin{array}{c}\text { Runoff as a } \\
\text { percentage } \\
\text { of rainfall }\end{array}$ & $\begin{array}{c}\text { Flow } \\
\text { volume, in } \\
\text { acre-feet }\end{array}$ & $\begin{array}{l}\text { Runoff, } \\
\text { in inches }\end{array}$ & $\begin{array}{c}\text { Runoff as a } \\
\text { percentage } \\
\text { of rainfall }\end{array}$ & $\begin{array}{c}\text { Flow } \\
\text { volume, in } \\
\text { acre-feet }\end{array}$ & $\begin{array}{l}\text { Runoff, } \\
\text { in inches }\end{array}$ & $\begin{array}{c}\text { Runoff as a } \\
\text { percentage } \\
\text { of rainfall }\end{array}$ \\
\hline 2009 & 22.2 & 5 & $<0.01$ & $<0.1$ & 2,280 & 2.88 & 13.0 & 7,220 & 8.59 & 38.7 \\
\hline 2010 & 31.0 & 917 & 0.47 & 1.5 & 22,600 & 28.56 & 92.1 & 24,800 & 29.50 & 95.2 \\
\hline 2011 & 18.7 & 1,820 & 0.93 & 5.0 & 19,600 & 24.78 & 132.5 & 19,000 & 22.65 & 121.1 \\
\hline 2013 & 17.4 & 4 & $<0.01$ & $<0.1$ & 324 & 0.41 & 2.4 & 2,470 & 2.94 & 16.9 \\
\hline 2014 & 21.3 & 120 & 0.06 & 0.3 & 377 & 0.48 & 2.2 & 4,790 & 5.70 & 26.7 \\
\hline 2015 & 18.1 & 72 & 0.04 & 0.2 & 203 & 0.26 & 1.4 & 3,840 & 4.57 & 25.2 \\
\hline 2016 & 18.4 & 478 & 0.24 & 1.3 & 1,290 & 1.62 & 8.8 & 2,280 & 2.72 & 14.8 \\
\hline
\end{tabular}

${ }^{1}$ Data from April through October are from site E1, data for November through March are from a High Plains Regional Climate site near Chaffee, North Dakota.

Table 6. Annual precipitation, flow volume, and runoff for monitoring sites at Dazey farm, North Dakota, 2010-15.

[--, not available]

\begin{tabular}{|c|c|c|c|c|c|c|c|}
\hline \multirow[b]{2}{*}{ Year } & \multirow[b]{2}{*}{$\begin{array}{l}\text { Rainfall April-0ctober, } \\
\text { in inches }\end{array}$} & \multicolumn{3}{|c|}{ D1b } & \multicolumn{3}{|c|}{ D3 } \\
\hline & & $\begin{array}{l}\text { Flow volume, } \\
\text { in acre-feet }\end{array}$ & $\begin{array}{l}\text { Runoff, } \\
\text { in inches }\end{array}$ & $\begin{array}{c}\text { Runoff as a } \\
\text { percentage of } \\
\text { rainfall }\end{array}$ & $\begin{array}{l}\text { Flow volume, } \\
\text { in acre-feet }\end{array}$ & $\begin{array}{l}\text { Runoff, } \\
\text { in inches }\end{array}$ & $\begin{array}{l}\text { Runoff as a } \\
\text { percentage of } \\
\text { rainfall }\end{array}$ \\
\hline 2010 & 20.6 & -- & -- & -- & 12,100 & 2.95 & 14.3 \\
\hline 2011 & 18.1 & -- & -- & -- & 8,080 & 1.97 & 10.9 \\
\hline 2012 & 9.4 & -- & -- & -- & 88 & 0.02 & 0.2 \\
\hline 2013 & 15.8 & 49 & 0.13 & 0.9 & 2,830 & 0.69 & 4.4 \\
\hline 2014 & 16.8 & 1,190 & 3.31 & 19.7 & 1,710 & 0.42 & 2.5 \\
\hline 2015 & 14.9 & 82 & 0.23 & 1.5 & 3,740 & 0.91 & 6.1 \\
\hline
\end{tabular}


ranged from 136 acre-feet (acre-ft) (2012) to 15,200 acre-ft (2011) (table 4). Site U1 had annual flow volumes ranging from 347 acre-ft (2012) to 6,210 acre-ft (2011). Measured runoff (flow volume divided by contributing drainage area multiplied by a conversion factor to obtain inches) consistently was highest at site $\mathrm{U} 1$ and was lowest at site U2. Annual runoff for site U1 ranged from 0.12 in. (2008) to 5.95 in. (2011) and for site U2 ranged from less than 0.01 in. (2012) to 0.54 in. (2009) (table 4). Most of the annual runoff was in March and April each year during spring snowmelt (fig. 5). The four highest monthly runoff values were measured at U1 in April 2009, March 2010, and March and April 2011 (fig. 5). The monthly runoff for these periods were considerably higher than any other monthly runoff totals from 2008 through 2015. The large monthly totals were not in months with high rainfall totals but were preceded by wet conditions in the previous fall months (September and October) and higher precipitation (rain or snow) in the preceding winter months (November-March). During 2013-15, there were several months with some of the highest precipitation values for 2008-15; however, these rain events were in the summer months when vegetation in the channel and surrounding cropland were actively growing and could uptake more moisture. In addition, the diversion ditch constructed in 2012 altered the flow of water, which may have had an effect on the runoff characteristics at sites U1 and U2, but because winter precipitation in 2013-15 was considerably less than 2009-12, it was difficult to quantify the effects of the diversion (fig. 5).

\section{Embden Farm}

Runoff characteristics at the Embden farm are complex because of the mix of surface runoff (measured at site E1) and flow through two separate drainage tile systems (sites E2 and E3; fig. 3). Annual flow volume at the surface runoff site (E1) ranged from 4 acre-ft (2013) to 1,820 acre-ft (2011) (table 5). Annual flow volumes for the drainage tiles sites were much greater than measured at site E1. Annual flow volumes for E2 ranged from 72 acre-ft (2012) to 22,600 acre-ft (2010). Annual

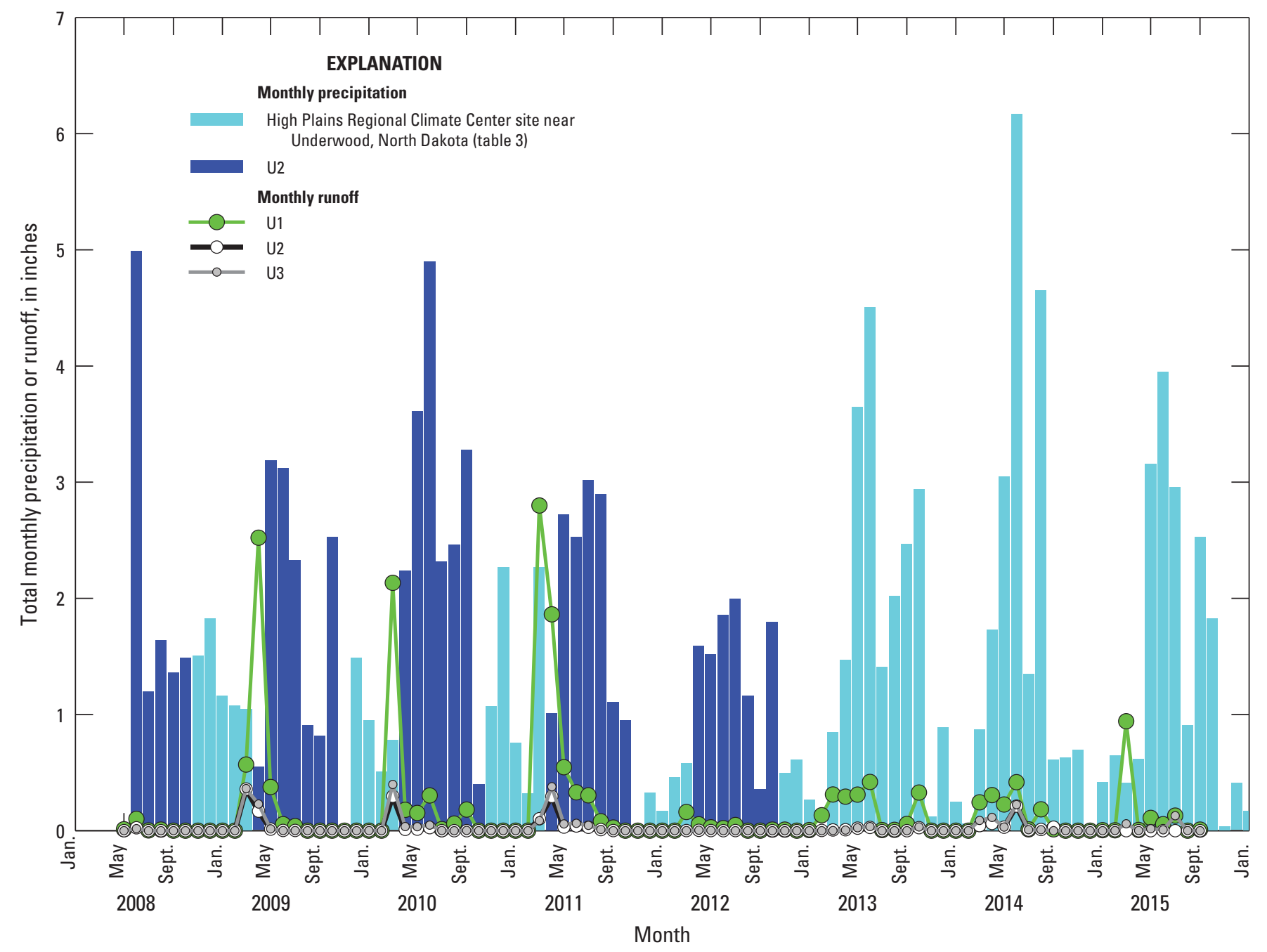

Figure 5. Monthly precipitation and runoff for monitoring sites at Underwood farm, North Dakota, 2008-16. 
flow volumes for E3 ranged from 772 acre-ft (2012) to 24,800 (2010) acre-ft. (table 5).

Site E1 generally only had runoff briefly in March and April during spring snowmelt events and during only a few large rain events throughout 2009-16; however, runoff was somewhat continuous at sites E2 and E3 throughout the year during years of increased precipitation such as in 2010 and 2011 (fig. 6). The largest monthly runoff at site E2 was in March 2010 at 7.5 in. and in April 2011 at 11.3 in. Likewise, site E3 had the largest runoff in March 2010 and April 2011 at 9.6 and 11.2 in., respectively (fig. 6). These large runoff volumes were preceded by high precipitation in the fall and winter. Although high monthly rainfall amounts were during summer months in subsequent years, the runoff amounts in the drainage tile sites were considerably less. Winter precipitation was considerably less in 2012-16 compared to 2009-11 (fig. 6). In 2010, sites E2 and E3 had monthly runoff that exceeded 0.5 in. every month from March 2010 through July 2011. Runoff at the drainage tiles also exceeded the amount of rainfall recorded at the site (table 5). This would indicate a large amount of stored moisture in the unsaturated zone and possibly water from a high shallow groundwater table from consecutive wet years being drained through the drainage tile sites E2 and E3 in this period. In subsequent years, most of the runoff flow through the drainage tile sites was measured in the summer months (May through July) and during months with increased rainfall amounts (fig. 6).

\section{Dazey Farm}

Runoff characteristics were difficult to determine because of equipment issues and environmental factors at sites D1a and D2 at Dazey farm. Flow volumes were measured for only a part of 2010 at sites D1a and D2 before site D2 was destroyed by high flows and sedimentation, after which the site was discontinued. Site D1a was later moved to another location (site D1b) farther upslope in 2013 (fig. 4).

Annual flow volumes at the most downstream site D3 for 2010-15 ranged from 88 acre-ft (2012) to 12,100 acre$\mathrm{ft} \mathrm{(2010)} \mathrm{(table} \mathrm{6).} \mathrm{Runoff} \mathrm{at} \mathrm{site} \mathrm{D3} \mathrm{ranged} \mathrm{from} 0.02$ in. (2012) to 2.95 in. (2010). Annual flow volumes for site D1b for 2013-15 ranged from 49 acre-ft (2013) to 1,190 acre-ft (2014), and runoff ranged from $0.13 \mathrm{in.}$ (2013) to $3.31 \mathrm{in.}$ (2014) (table 6). The largest monthly runoff volumes at sites D1b and D3 were in March and April during spring snowmelt runoff and rain events. Site D1b had only one period of measurable monthly runoff that was in March and April 2014. Monthly runoff at site D3 was the greatest in March 2010 (1.9 in.) and in April 2011 (1.5 in.) (fig. 7). Winter

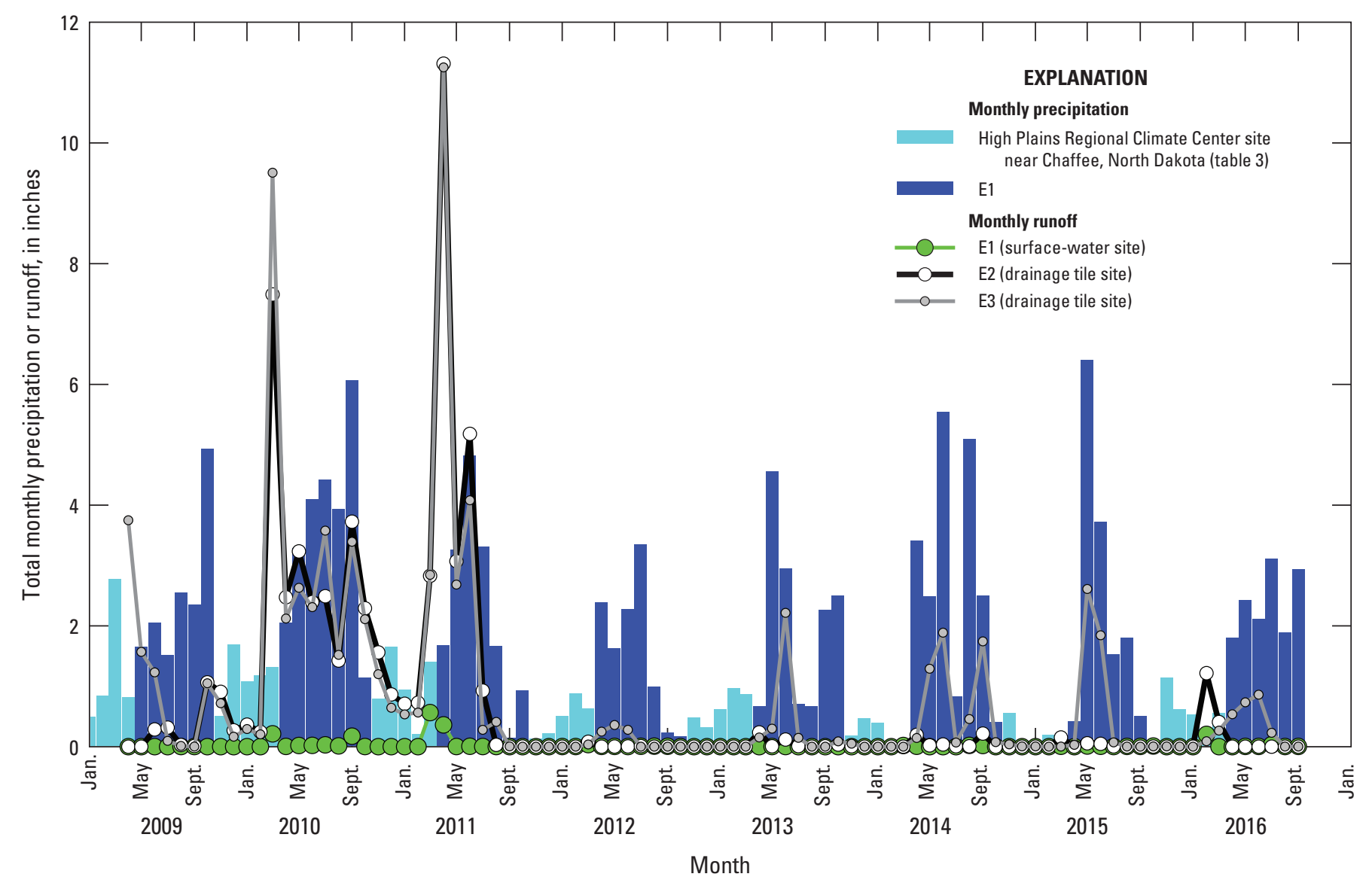

Figure 6. Monthly precipitation and runoff for monitoring sites at Embden farm, North Dakota, 2009-16. 


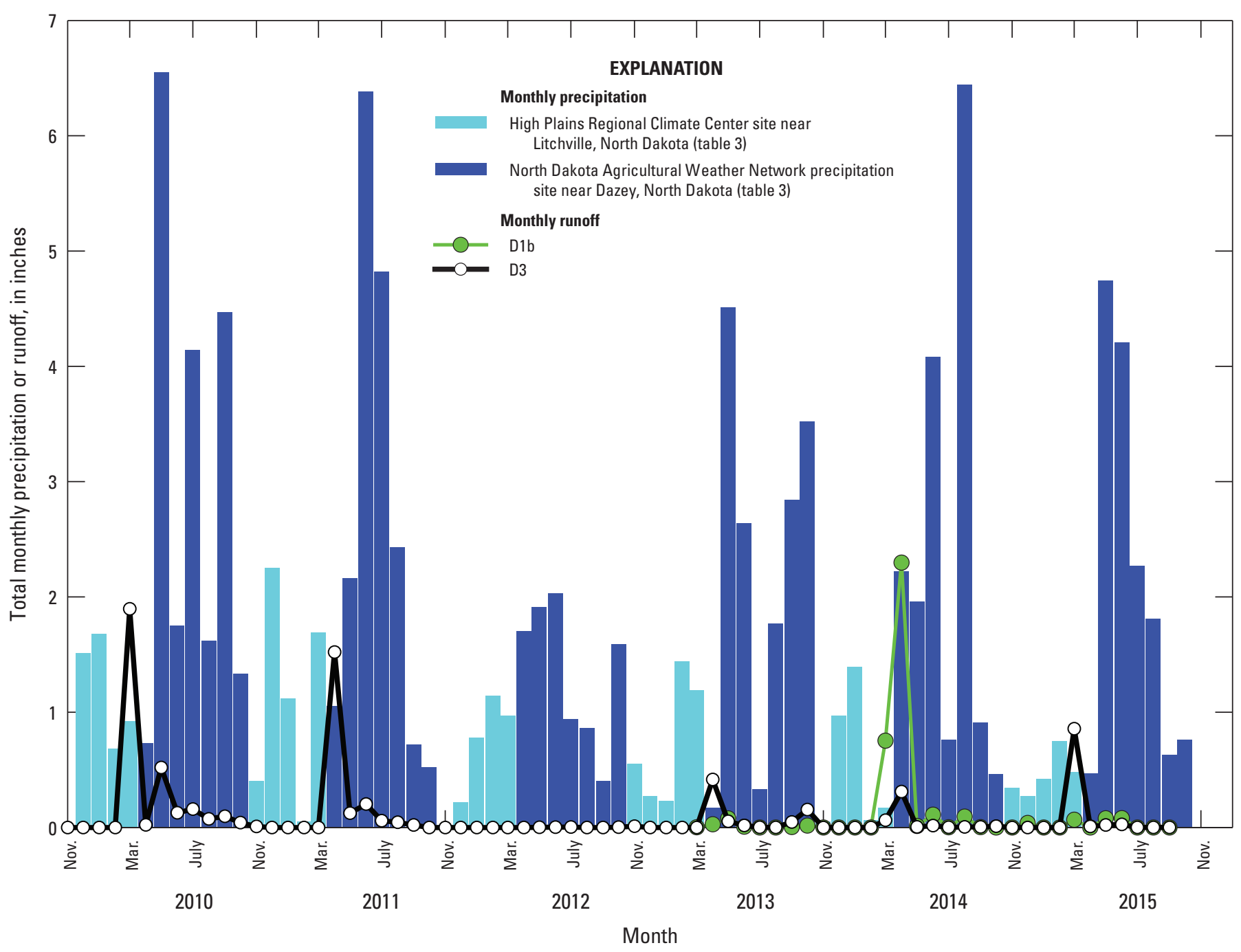

Figure 7. Monthly precipitation and runoff for monitoring sites at Dazey farms, North Dakota, 2010-15.

precipitation used for comparison may not accurately reflect the conditions at the Dazey farm because the nearest site that recorded winter precipitation was about 47 mi south of Dazey farm near Litchville, N. Dak. (High Plains Regional Climate Center, 2017) (fig. 1).

\section{Water-Quality Characteristics}

Water-quality characteristics of sites at each farm are described in terms of constituent concentrations, loads, and yields. Loads (mass per time) were estimated to determine the mass of constituents being transported at the sites associated with the three farms. Yields (load per drainage area) provide a way to compare constituent transport among sites with different drainage areas. Data analysis in this section mainly is focused on chloride, total ammonia, total nitrate plus nitrite, total phosphorus, and suspended sediment. A small number of samples were analyzed for additional constituents such as major ions, iron, and manganese, but these constituents are not extensively discussed in this report and are presented in appendix table 1-1. All water-quality data for these sites are stored and available from the USGS NWIS database (U.S. Geological Survey, 2017).

\section{Underwood Farm}

At Underwood farm from June 2008 through September 2015, about 227 samples were collected from site U1, 135 samples from site U2, and 174 samples from site U3 (table 7). Not all samples were analyzed for the same constituents, so the number of values for individual constituents varied throughout the period (table 7). Runoff was sampled generally during spring snowmelt and during rainfall events at the sites (fig. 8). 
Table 7. Summary of water-quality constituent concentrations for monitoring sites at Underwood farm, North Dakota, 2008-15.

[Number in parentheses is the U.S. Geological Survey National Water Information System parameter code; $\mathrm{ft}^{3} / \mathrm{s}$, cubic foot per second; $\mu \mathrm{S} / \mathrm{cm}$ at $25^{\circ} \mathrm{C}$, microsiemen per centimeter at 25 degrees Celsius; $\mathrm{mg} / \mathrm{L}$, milligram per liter; N, nitrogen; P, phosphorus, $<$, less than]

\begin{tabular}{|c|c|c|c|c|c|c|c|c|c|c|c|c|c|c|}
\hline \multirow[t]{2}{*}{$\begin{array}{c}\text { Site } \\
\text { (fig. 2) }\end{array}$} & \multirow[t]{2}{*}{ Description } & $\begin{array}{l}\text { Instan- } \\
\text { taneous } \\
\text { discharge, } \\
\text { in } \mathrm{ft}^{3} / \mathrm{s}\end{array}$ & $\begin{array}{c}\text { Specific } \\
\text { conduc- } \\
\text { tance, } \\
\text { laboratory, } \\
\text { HS/cm at } \\
25^{\circ} \mathrm{C}\end{array}$ & $\begin{array}{l}\text { Suspended } \\
\text { solids, } \\
\text { in } \mathrm{mg} / \mathrm{L}\end{array}$ & $\begin{array}{c}\text { Chloride, } \\
\text { in } \mathrm{mg} / \mathrm{L}\end{array}$ & $\begin{array}{l}\text { Dissolved } \\
\text { (filtered) } \\
\text { ammonia, } \\
\text { in } \mathrm{mg} / \mathrm{L} \\
\text { as } \mathrm{N}\end{array}$ & $\begin{array}{c}\text { Total } \\
\text { (unfiltered) } \\
\text { ammonia, } \\
\text { in } \mathrm{mg} / \mathrm{L} \\
\text { as } \mathrm{N}\end{array}$ & $\begin{array}{l}\text { Dissolved } \\
\text { (filtered) } \\
\text { nitrate plus } \\
\text { nitrite, in } \\
\text { mg/L as N }\end{array}$ & $\begin{array}{c}\text { Total } \\
\text { (unfiltered) } \\
\text { nitrate plus } \\
\text { nitrite, in } \\
\mathrm{mg} / \mathrm{L} \text { as N }\end{array}$ & $\begin{array}{l}\text { Dissolved } \\
\text { (filtered) } \\
\text { phosphorus, } \\
\text { in } \mathrm{mg} / \mathrm{L} \text { as } \mathrm{P}\end{array}$ & $\begin{array}{c}\text { Total } \\
\text { (unfiltered) } \\
\text { phospho- } \\
\text { rus, } \\
\text { in } \mathrm{mg} / \mathrm{L} \\
\text { as } \mathrm{P}\end{array}$ & $\begin{array}{c}\text { Total } \\
\text { dissolved } \\
\text { (filtered) } \\
\text { nitrogen, in } \\
\text { mg/L as N }\end{array}$ & $\begin{array}{c}\text { Total } \\
\text { (unfiltered) } \\
\text { nitrogen, in } \\
\mathrm{mg} / \mathrm{L} \text { as } \mathrm{N}\end{array}$ & $\begin{array}{c}\text { Sus- } \\
\text { pended- } \\
\text { sediment, } \\
\text { in } \mathrm{mg} / \mathrm{L}\end{array}$ \\
\hline & & (00061) & (90095) & (00530) & (00940) & (00608) & $(00610)$ & (00631) & $(00630)$ & (00666) & (00665) & (62854) & (62855) & $(80154)$ \\
\hline \multirow[t]{5}{*}{ U1 } & $\begin{array}{c}\text { Number of } \\
\text { samples }\end{array}$ & 233 & 227 & 225 & 225 & 87 & 223 & 87 & 223 & 87 & 226 & 83 & 222 & 209 \\
\hline & Minimum & 0.0 & 275 & $<5$ & 7 & 0.54 & 0.39 & $<0.03$ & $<0.03$ & 1.3 & 0.59 & 7.4 & 4.6 & 17 \\
\hline & Maximum & 8.2 & 6,990 & 11,300 & 523 & 179 & 299 & 641 & 654 & 35 & 117 & 904 & 924 & 9,280 \\
\hline & Median & 0.3 & 2,080 & 255 & 129 & 5.6 & 5.9 & 2.3 & 1.3 & 10 & 14 & 31.6 & 34 & 465 \\
\hline & Mean & 0.8 & 2,245 & 519 & 159 & 18 & 18 & 9.9 & 5.8 & 11 & 16.6 & 56.7 & 56 & 811 \\
\hline \multirow[t]{5}{*}{$\mathrm{U} 2$} & $\begin{array}{c}\text { Number of } \\
\text { samples }\end{array}$ & 137 & 135 & 135 & 135 & 81 & 133 & 81 & 133 & 81 & 135 & 79 & 133 & 127 \\
\hline & Minimum & 0.0 & 73 & 5 & 3 & $<0.03$ & 0.05 & $<0.03$ & $<0.03$ & 0.35 & 0.30 & 1.8 & 1.1 & 5 \\
\hline & Maximum & 21.0 & 3,160 & 1,310 & 306 & 48 & 51 & 26 & 28 & 14 & 21 & 57 & 97 & 1,830 \\
\hline & Median & 0.7 & 1,030 & 39 & 41 & 1.1 & 1.3 & 2.3 & 2.5 & 2.9 & 5.1 & 10 & 15 & 89 \\
\hline & Mean & 2.3 & 1,029 & 139 & 59 & 3.4 & 3.7 & 3.2 & 3.8 & 3.4 & 6.0 & 13 & 18 & 227 \\
\hline \multirow[t]{5}{*}{ U3 } & $\begin{array}{c}\text { Number of } \\
\text { samples }\end{array}$ & 169 & 174 & 165 & 172 & 58 & 164 & 58 & 164 & 58 & 165 & 57 & 164 & 168 \\
\hline & Minimum & 0.0 & 87 & $<5$ & $<3$ & $<0.03$ & $<0.03$ & $<0.03$ & $<0.03$ & 0.73 & 0.46 & 2.1 & 1.8 & 1 \\
\hline & Maximum & 26.0 & 2,750 & 360 & 183 & 15 & 15 & 19 & 20 & 8.4 & 9.7 & 38 & 43 & 610 \\
\hline & Median & 0.7 & 1,220 & 20 & 60 & 0.95 & 0.97 & 1.6 & 1.4 & 2.9 & 3.7 & 9.3 & 11 & 29 \\
\hline & Mean & 1.8 & 1,287 & 42 & 62 & 2.4 & 2.0 & 2.8 & 3.0 & 3.2 & 4.0 & 11 & 12 & 73 \\
\hline
\end{tabular}



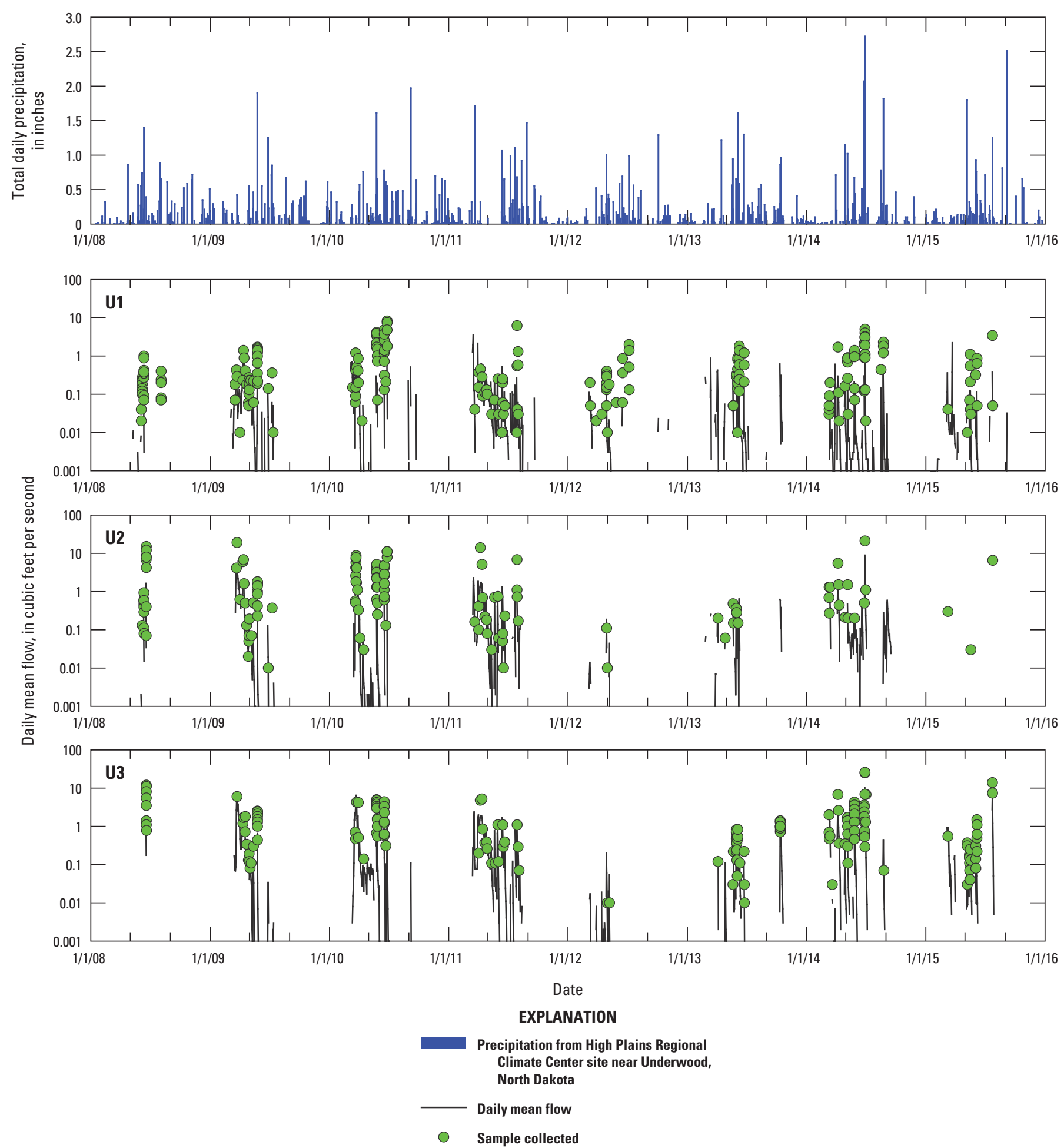

Figure 8. Daily mean flow, daily precipitation, and samples collected at monitoring sites at Underwood farm, North Dakota, 2008-15. 


\section{Concentrations}

Chloride concentrations measured at Underwood farm generally were highest at site U1 and lowest at site U2 (fig. 9). In general, chloride concentrations also were higher at Underwood farm compared to Dazey and Embden farms (fig. 9). Potential sources of chloride at Underwood farm could include soils in the area and feedlot manure that may have feed additives that include salts (Mullaney and others, 2009; Hem, 1985). Site U1 had much higher chloride concentrations than the downstream sites with a median of 129 milligrams per liter (mg/L; fig. 9; table 7), indicating sources from the feedlot. Concentrations decreased substantially at site U2 with a median concentration of $41 \mathrm{mg} / \mathrm{L}$. The channel is highly vegetated between sites $\mathrm{U} 1$ and $\mathrm{U} 2$, and it is likely that most of the chloride was attenuated by plant uptake (White and Broadley, 2001) and dilution from additional runoff at site U2. Site U3 had slightly higher concentrations than site U2 with a median concentration of $60 \mathrm{mg} / \mathrm{L}$. The higher concentrations at site U3 may be the result of timing of the runoff sampled or from runoff from the surrounding cropland. Chloride concentrations from samples collected during spring snowmelt runoff may not be attenuated as much in the spring when there is a lack of active plant growth compared to samples collected later in the summer months during rainfall events.

Nutrient concentrations varied among sites at Underwood farm depending on the nitrogen and phosphorus species. Potential sources of nutrients related to agricultural activities could include animal manure in the feedlot, and fertilizer and manure applications to the surrounding cropland. Natural sources of nitrogen and phosphorus could include fixation of atmospheric nitrogen by plants and animals, dissolution of phosphorus-bearing rocks or minerals in the soil, and oxidation of organic matter, including soil organic matter and decaying plants and animals (Hem, 1985). Nitrate also can be produced from ammonia through the process of nitrification where ammonia is converted to nitrate through oxidation (U.S. Environmental Protection Agency, 2015).

Total ammonia and total phosphorus had the highest concentrations at site $\mathrm{U} 1$ and decreased sequentially at sites U2 and U3 downstream (fig. 9). Total ammonia and phosphorus concentrations at the sites for Underwood farm also generally were higher than concentrations at Dazey and Embden farms (fig. 9). Median total ammonia concentrations at sites $\mathrm{U} 1, \mathrm{U} 2$, and $\mathrm{U} 3$ were $5.9,1.3$, and $0.97 \mathrm{mg} / \mathrm{L}$ as nitrogen, respectively (table 7). Median total phosphorus concentrations at sites $\mathrm{U} 1, \mathrm{U} 2$, and $\mathrm{U} 3$ were $14,5.1$, and $3.7 \mathrm{mg} / \mathrm{L}$ as phosphorus, respectively. The decrease in total ammonia and phosphorus from upstream to downstream sites likely is due to plant uptake in the vegetated channel and dilution during runoff (Hem, 1985). In addition, ammonia could be decreasing due to nitrification. Phosphorus also can be attached to sediment, so some of the phosphorus could be removed as sediment from the feedlot is trapped by the vegetation as runoff travels through the channel downstream.
Nitrate plus nitrite generally had the lowest concentrations at site $\mathrm{U} 1$ and the highest concentrations at site $\mathrm{U} 2$, although median concentrations did not vary substantially among sites (fig. 9). Median total nitrate plus nitrite concentrations for sites U1, U2, and U3 were $1.3,2.5$, and $1.4 \mathrm{mg} / \mathrm{L}$ as nitrogen, respectively. Several reasons are possible for why nitrate plus nitrite values for site $\mathrm{U} 2$ were highest among the three sites. Most of the nitrogen from animal manure that would be present in the feedlot is likely in the form of ammonia (U.S. Environmental Protection Agency, 2015), resulting in low nitrate plus nitrite values at site U1. As runoff travels down the channel, the ammonia could be converted to nitrate though nitrification creating higher concentration at site U2. In addition, site $\mathrm{U} 2$ receives additional runoff from a culvert east of site U1 that gathers runoff from croplands north of the county road that could have higher concentrations of nitrate plus nitrite. Site U3 could have slightly lower concentrations because of plant uptake in the vegetated channel.

Suspended-sediment concentrations decreased from site U1 downstream to site U3 (fig. 9). Higher concentrations at site $\mathrm{U} 1$ are likely from soil that is exposed and loosened in the feedlot and is readily transported during runoff. As runoff travels through the vegetated channel to sites $\mathrm{U} 2$ and $\mathrm{U} 3$, the sediment likely is deposited and caught up in the vegetation and is diluted by additional runoff from flow into site $\mathrm{U} 2$. Median suspended-sediment concentrations for sites U1, U2, and U3 were 465, 89, and $29 \mathrm{mg} / \mathrm{L}$, respectively (table 7).

\section{Loads and Yields}

Annual loads (March through October) were estimated for the three sites at Underwood farm for 2009-15 (fig. 10; table 8). Data collection began in June 2008, so annual loads were not estimated for that year because the dataset was incomplete. Annual loads for chloride at all three sites were the greatest in 2011 and the least in 2012, which coincided with years of the greatest and least annual flow volume, respectively (tables 4, 8). Annual chloride loads ranged from 1,800 to 16,100 pounds per year $(\mathrm{lb} / \mathrm{yr})$ at site $\mathrm{U} 1$, from 453 to $6,420 \mathrm{lb} / \mathrm{yr}$ at site $\mathrm{U} 2$, and from 386 to $9,890 \mathrm{lb} / \mathrm{yr}$ at site $\mathrm{U} 3$ (fig. 10; table 8). Total ammonia had a similar pattern at sites U1 and U3; annual loads were the greatest in 2011 and the least in 2012. Site U2 had the greatest loads in 2009. Annual total ammonia loads ranged from 46 to $11,400 \mathrm{lb} / \mathrm{yr}$ as nitrogen at site $\mathrm{U} 1$, from 4 to $2,630 \mathrm{lb} / \mathrm{yr}$ as nitrogen at site $\mathrm{U} 2$, and from less than 1 to $750 \mathrm{lb} / \mathrm{yr}$ as nitrogen at site U3 (fig. 10; table 8).

In general, annual chloride loads decreased from upstream to downstream, indicating the feedlot as the likely source. Two exceptions were in 2009 and 2014, which may have been either from timing of when most of the loads were delivered or from some other unknown source. Manure from the feedlots is spread periodically on the surrounding fields and could be an additional source of chloride at sites U2 

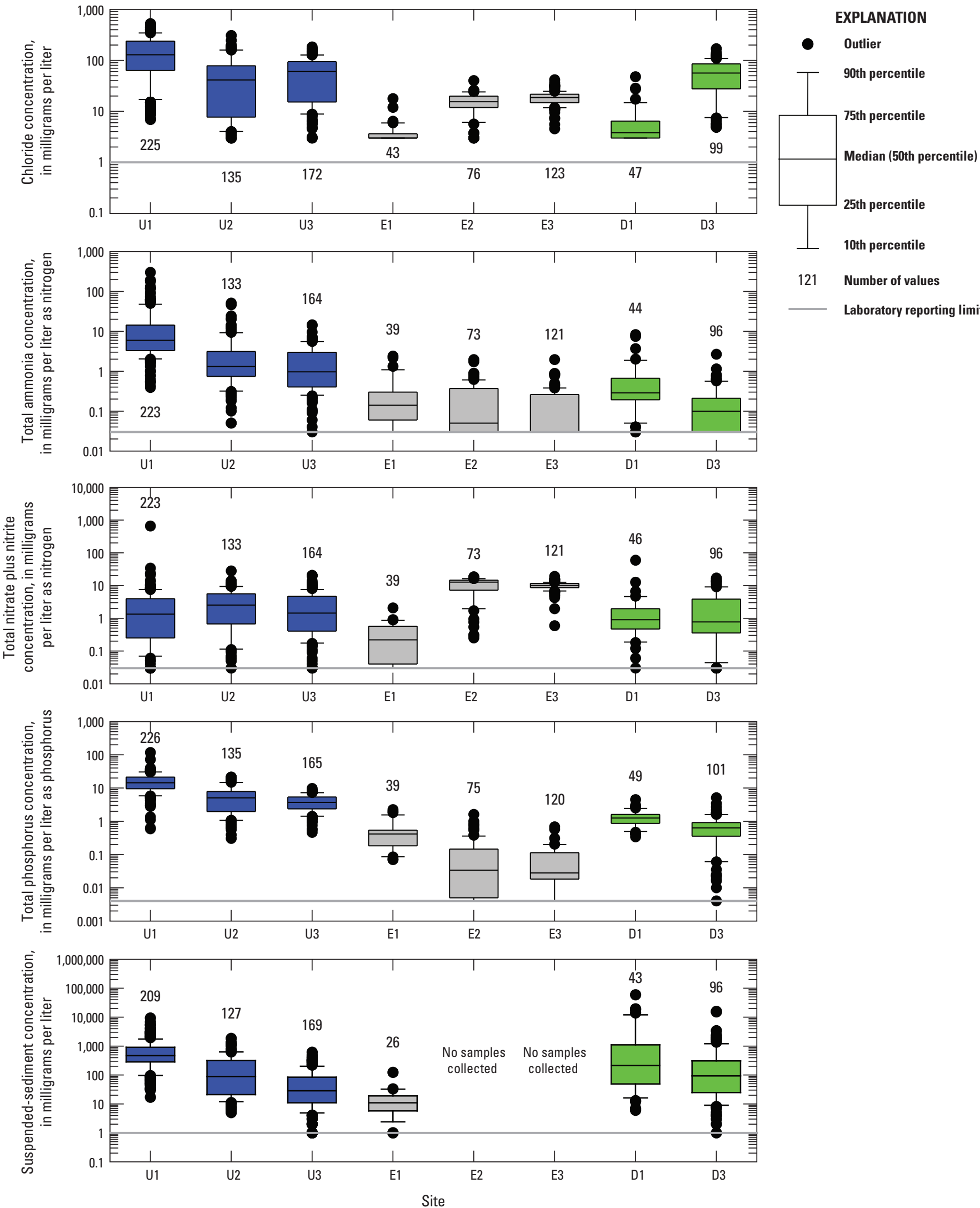

Figure 9. Distribution of constituent concentrations at monitoring sites at Underwood, Embden, and Dazey farms, North Dakota, $2008-16$. 
and U3. There also could be natural sources of chloride from soils in the area that contribute to the loads at the two downstream sites. Annual total ammonia loads were less at downstream sites every year from 2009 to 2015 ; loads at site U3 averaged 11 percent of the annual load at site U1, indicating the feedlot as the likely source, but also that a considerable amount of mass is retained by the vegetated channel and not transported past site U3, the most downstream site.

Nitrate plus nitrite loads displayed a different pattern than chloride and total ammonia, indicating possible different sources. The greatest nitrate plus nitrite loads were in 2010 at site U1 and in 2014 at sites U2 and U3. The least annual nitrate plus nitrite loads occurred in 2013 at site U1 and in 2012 at sites U2 and U3. Annual nitrate plus nitrite loads also were consistently greater at sites U2 and U3 when compared to site U1 except for 2012. Annual nitrate plus nitrite loads ranged from 30 to $87 \mathrm{lb} / \mathrm{yr}$ as nitrogen at site $\mathrm{U} 1$, from 7 to $628 \mathrm{lb} / \mathrm{yr}$ as nitrogen at site $\mathrm{U} 2$, and from 8 to $628 \mathrm{lb} / \mathrm{yr}$ as nitrogen at site U3 (fig. 10; table 8).

Annual total phosphorus loads were greatest in 2011 at sites U1 and U3 and in 2014 at site U2 and were least in 2012 at sites U1, U2, and U3. Annual total phosphorus loads ranged from 100 to $1,770 \mathrm{lb} / \mathrm{yr}$ as phosphorus at site $\mathrm{U} 1$, from 14 to $1,250 \mathrm{lb} / \mathrm{yr}$ as phosphorus at site $\mathrm{U} 2$, and from 4 to $713 \mathrm{lb} / \mathrm{yr}$ as phosphorus at site U3 (fig. 10; table 8). Phosphorus can be adsorbed and transported with sediment, and the pattern of annual total phosphorus loads may be explained by the same pattern in annual suspended-sediment load.

Suspended-sediment loads also were greatest in 2011 at sites U1 and U3 and in 2014 at site U2 and were the least in 2015 at site U1 and in 2012 at sites U2 and U3 (fig. 10; table 8). Annual suspended-sediment loads ranged from 3,060 to $69,800 \mathrm{lb} / \mathrm{yr}$ at site $\mathrm{U} 1$, from 338 to $15,300 \mathrm{lb} / \mathrm{yr}$ at site $\mathrm{U} 2$, and from 150 to $25,000 \mathrm{lb} / \mathrm{yr}$ at site U3 (fig. 10; table 8).

Patterns in annual load may be explained by when most of the load is transported during the year. Chloride, total ammonia, total phosphorus, and suspended sediment were transported past site U1 mostly in March, and the least from July through October (fig. 11; appendix table 1-3). This could be explained by hydrology and the operation of the feedlot. Beef cattle are kept in the feedlot throughout the winter months. During this time, manure in the feedlot can accumulate, the ground is continuously broken up, and there is little runoff to move any material from the feedlot. In the spring when snowmelt and spring rains occur, the material that has built up through the winter is readily available to be transported off the feedlot. After the cattle are moved out of the feedlot in the spring and vegetation is actively growing, less material is available for transport in the summer months, even during large rainfall events. In an effort to mitigate this problem, the producer constructed a ditch around the feedlot in 2012 that reduces the amount of runoff going through the feedlot, and as a result reduced the amount of material transported from the farm.
Mean monthly loads of total ammonia were considerably less at sites U2 and U3 compared to site U1 and demonstrated the same pattern of occurrence, whereas chloride, total phosphorus, and suspended-sediment loads at sites U2 and U3 had a slightly different pattern indicating that other processes may control the transport of these constituents past these sites. Larger loads in June for suspended sediment at site U2 likely were due to large June rainfall amounts when fields have been freshly plowed and planted, loosening soil material and making it more readily available for transport. Larger loads in June of total phosphorus may be attributed to fertilizer application in late May or early June in conjunction with some of the highest monthly rainfall (figs. 5 and 11). Large chloride loads in May and June at sites U2 and U3 may be attributed to natural sources such as soils that are washed off the landscape during rainfall in May and June when freshly planted fields have little vegetative cover holding the soils in place or could be from freshly applied manure being washed off the surrounding cropland during rainfall events (fig. 11).

Monthly nitrate plus nitrite loads had a different pattern than the other constituents, indicating other possible sources such as fertilizer application in the surrounding cropland. Although the greatest nitrate plus nitrite loads at site U1 were in March, a large amount of nitrate plus nitrite was transported past sites U2 and U3 in March through June, and the greatest monthly loads were in June for site U2 and in March for site U3 (fig. 11). Most of the fertilizer application in the surrounding crop was from late April into June during and after planting. The timing of the application depended on crop type and weather conditions each year. The transport of nutrients from fertilizer application is dependent on how soon rainfall occurs after fertilizer application. This also may explain the large annual loads in 2014 at sites U2 and U3 (fig. 10). June 2014 had the greatest monthly precipitation for 2009-15, which coincided closely with the period of fertilizer application in the surrounding cropland. About one-half of the annual loads of nitrate plus nitrite in 2014 at sites U2 and U3 were transported in June (appendix table 1-3).

Fertilizer application in fields surrounding the waterway where the three Underwood farm monitoring sites are located varied annually depending on crop type (table 9). Application data were only available from the producer for the fields immediately adjacent to the waterway south of the county road and for the fields directly north of the feedlot and east of the feedlot on the north side of the county road (fig. 2). Information on fertilizer application was not available for most of the northern part of the drainage area. Out of the 1,911 total acres included in the drainage area for U3, fertilizer application data were only available for about 164 acres. Within the drainage area for site U3 (that also would include drainage areas for sites $\mathrm{U} 1$ and $\mathrm{U} 2$ ), total annual nitrogen application ranged from $1,580 \mathrm{lb} / \mathrm{yr}$ in 2014 , when mostly corn and spring wheat were planted, to $20,200 \mathrm{lb} / \mathrm{yr}$ in 2015 , when spring wheat and soybeans again were planted (table 9). Annual application rates for nitrogen ranged from about 10 pounds per year per 


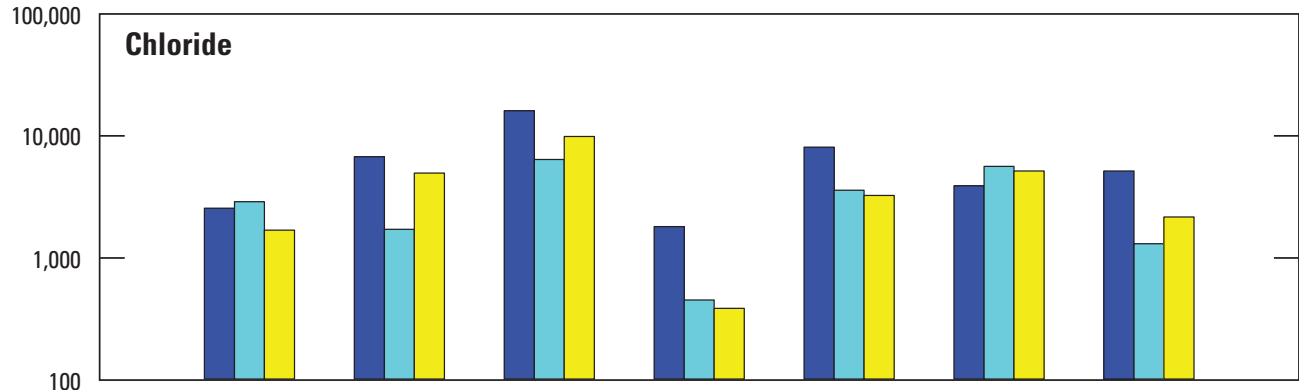

EXPLANATION
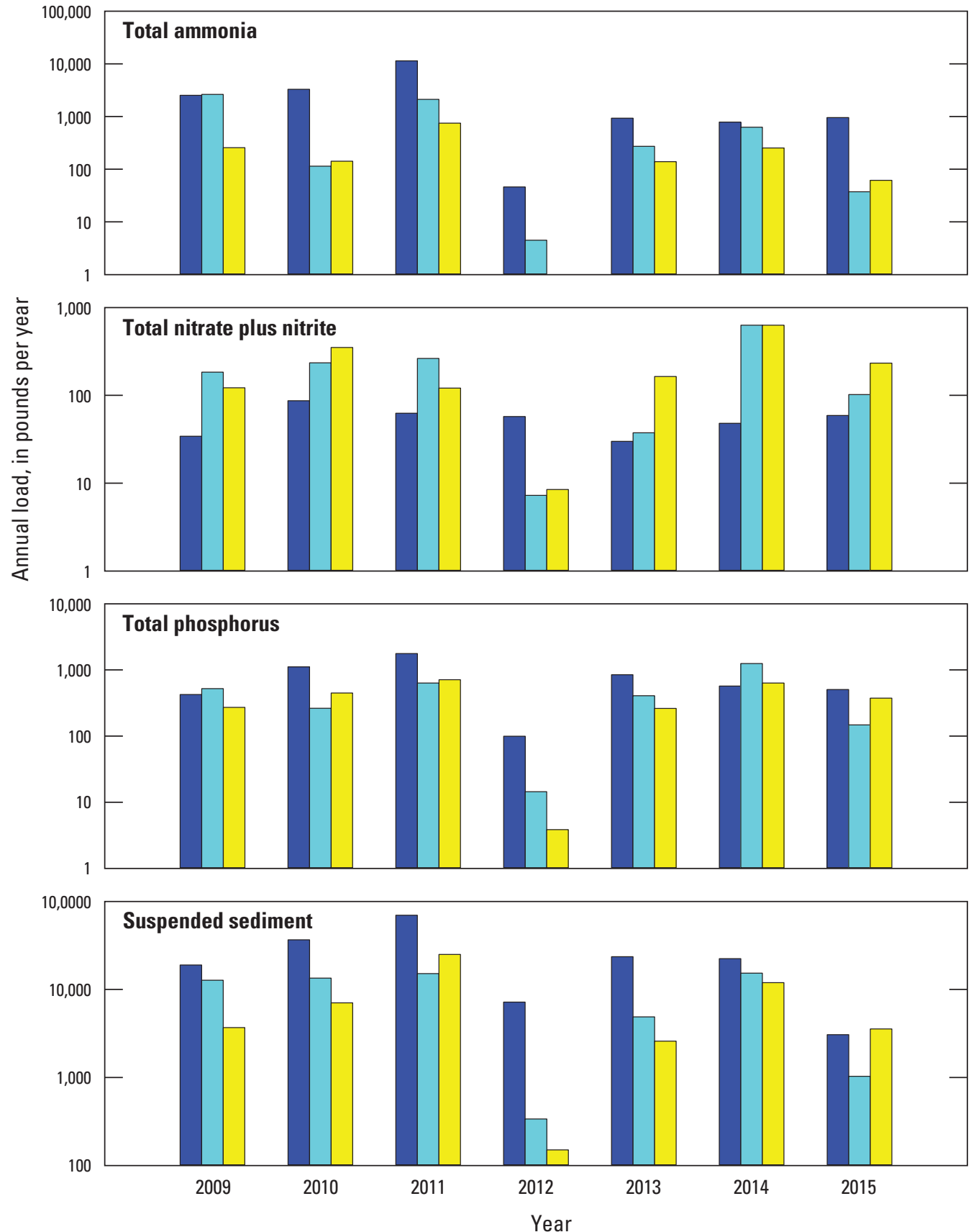

Figure 10. Annual loads estimated for monitoring sites at Underwood farm, North Dakota, 2009-15. 
Table 8. Annual loads and yields for Underwood farm, North Dakota, 2009-15.

$[\mathrm{N}$, nitrogen; $\mathrm{P}$, phosphorus, $<$, less than $]$

\begin{tabular}{|c|c|c|c|c|c|c|c|c|c|c|c|}
\hline \multirow[b]{2}{*}{ Year } & \multirow[b]{2}{*}{$\begin{array}{l}\text { Flow, in } \\
\text { acre-feet } \\
\text { per year }\end{array}$} & \multicolumn{5}{|c|}{ Load, in pounds per year } & \multicolumn{5}{|c|}{ Yield, in pounds per year per acre } \\
\hline & & Chloride & $\begin{array}{c}\text { Total } \\
\text { (unfiltered) } \\
\text { ammonia, } \\
\text { as N }\end{array}$ & $\begin{array}{c}\text { Total } \\
\text { (unfiltered) } \\
\text { nitrate plus } \\
\text { nitrite, } \\
\text { as N }\end{array}$ & $\begin{array}{c}\text { Total } \\
\text { (unfiltered) } \\
\text { phosphorus, } \\
\text { as P }\end{array}$ & $\begin{array}{c}\text { Sus- } \\
\text { pended } \\
\text { sediment }\end{array}$ & Chloride & $\begin{array}{c}\text { Total } \\
\text { (unfiltered) } \\
\text { ammonia, } \\
\text { as N }\end{array}$ & $\begin{array}{c}\text { Total } \\
\text { (unfiltered) } \\
\text { nitrate plus } \\
\text { nitrite, } \\
\text { as N }\end{array}$ & $\begin{array}{c}\text { Total } \\
\text { (unfiltered) } \\
\text { phospho- } \\
\text { rus, } \\
\text { as P }\end{array}$ & $\begin{array}{c}\text { Sus- } \\
\text { pended } \\
\text { sediment }\end{array}$ \\
\hline \multicolumn{12}{|c|}{ Site U1 } \\
\hline 2009 & 26 & 2,560 & 2,520 & 34 & 425 & 19,000 & 29 & 29 & 0.39 & 4.9 & 218 \\
\hline 2010 & 22 & 6,730 & 3,280 & 87 & 1,110 & 36,700 & 77 & 38 & 1.0 & 13 & 422 \\
\hline 2011 & 43 & 16,100 & 11,400 & 63 & 1,770 & 69,800 & 185 & 131 & 0.72 & 20 & 802 \\
\hline 2012 & 2 & 1,800 & 46 & 57 & 100 & 7,180 & 21 & 0.53 & 0.66 & 1.1 & 83 \\
\hline 2013 & 13 & 8,080 & 931 & 30 & 846 & 23,500 & 93 & 11 & 0.34 & 9.7 & 270 \\
\hline 2014 & 10 & 3,900 & 783 & 48 & 571 & 22,400 & 45 & 9.0 & 0.55 & 6.6 & 257 \\
\hline 2015 & 9 & 5,170 & 953 & 59 & 505 & 3,060 & 59 & 11 & 0.68 & 5.8 & 35 \\
\hline Mean & 18 & 6,330 & 2,840 & 54 & 761 & 25,900 & 73 & 33 & 0.62 & 8.7 & 298 \\
\hline \multicolumn{12}{|c|}{ Site U2 } \\
\hline 2009 & 87 & 2,890 & 2,630 & 184 & 523 & 12,700 & 1.5 & 1.4 & 0.10 & 0.27 & 6.6 \\
\hline 2010 & 55 & 1,710 & 114 & 235 & 263 & 13,400 & 0.89 & 0.06 & 0.12 & 0.14 & 7.0 \\
\hline 2011 & 81 & 6,420 & 2,110 & 263 & 633 & 15,100 & 3.3 & 1.1 & 0.14 & 0.33 & 7.9 \\
\hline 2012 & $<1$ & 453 & 4 & 7 & 14 & 338 & 0.24 & $<0.01$ & $<0.01$ & $<0.01$ & 0.18 \\
\hline 2013 & 14 & 3,590 & 271 & 38 & 408 & 4,880 & 1.9 & 0.14 & 0.02 & 0.21 & 2.5 \\
\hline 2014 & 62 & 5,620 & 627 & 628 & 1,250 & 15,300 & 2.9 & 0.33 & 0.33 & 0.65 & 8.0 \\
\hline 2015 & 12 & 1,310 & 37 & 102 & 148 & 1,030 & 0.68 & 0.02 & 0.05 & 0.08 & 0.5 \\
\hline Mean & 45 & 3,140 & 828 & 208 & 463 & 8,960 & 1.6 & 0.43 & 0.11 & 0.24 & 4.7 \\
\hline \multicolumn{12}{|c|}{ Site U3 } \\
\hline 2009 & 100 & 1,690 & 256 & 122 & 272 & 3,680 & 0.86 & 0.13 & 0.06 & 0.14 & 1.9 \\
\hline 2010 & 85 & 4,960 & 142 & 350 & 447 & 7,040 & 2.5 & 0.07 & 0.18 & 0.23 & 3.6 \\
\hline 2011 & 105 & 9,890 & 750 & 121 & 713 & 25,000 & 5.0 & 0.38 & 0.06 & 0.36 & 13 \\
\hline 2012 & $<1$ & 386 & $<1$ & 8 & 4 & 150 & 0.20 & $<0.01$ & $<0.01$ & $<0.01$ & 0.08 \\
\hline 2013 & 16 & 3,260 & 139 & 164 & 262 & 2,580 & 1.6 & 0.07 & 0.08 & 0.13 & 1.3 \\
\hline 2014 & 78 & 5,170 & 254 & 628 & 635 & 11,900 & 2.6 & 0.13 & 0.32 & 0.32 & 6.0 \\
\hline 2015 & 34 & 2,160 & 62 & 232 & 375 & 3,560 & 1.1 & 0.03 & 0.12 & 0.19 & 1.8 \\
\hline Mean & 60 & 3,930 & 229 & 232 & 387 & 7,700 & 2.0 & 0.12 & 0.12 & 0.20 & 3.9 \\
\hline
\end{tabular}

acre (lb/yr/acre) in 2014 to $123 \mathrm{lb} / \mathrm{yr} /$ acre in 2015 (table 9). Total annual phosphorus application ranged from $932 \mathrm{lb} / \mathrm{yr}$ in 2013 to 7,240 lb/yr in 2012 when corn was planted. Annual application rates for phosphorus ranged from $6 \mathrm{lb} / \mathrm{yr} / \mathrm{acre}$ in 2013 to $44 \mathrm{lb} / \mathrm{yr} / \mathrm{acre}$ in 2012 (table 9). As mentioned earlier, animal manure also was spread on various fields periodically throughout the period as a form of fertilizer.

Annual yields (load per drainage area) were computed for the three sites at Underwood farm for comparison of the sites in terms of the mass of constituents transported past each site per acre of contributing runoff to each site (fig. 12; table 8). Depending on the constituent, annual yields were between 2 and 1,000 times greater at site U1, compared to sites $\mathrm{U} 2$ and $\mathrm{U} 3$, mainly because of a combination of higher measured concentrations and smaller contributing drainage area for site U1. Sites U2 and U3 generally had similar annual yields for all constituents. Annual chloride yields ranged from $0.20 \mathrm{lb} / \mathrm{yr} /$ acre at site U3 in 2012 to $185 \mathrm{lb} / \mathrm{yr} /$ acre at site U1 in 2011. Annual total ammonia yields ranged from less than $0.01 \mathrm{lb} / \mathrm{yr} /$ acre as nitrogen at sites U2 and U3 in 2012 and $131 \mathrm{lb} / \mathrm{yr} /$ acre as nitrogen at site U1 in 2011. Annual total nitrate plus nitrite yields ranged from less than $0.01 \mathrm{lb} / \mathrm{yr} /$ acre as nitrogen at sites U2 and U3 in 2012 to $1.0 \mathrm{lb} / \mathrm{yr} / \mathrm{acre}$ as nitrogen at site $\mathrm{U} 1$ in 2010 . Annual total phosphorus yields 




EXPLANATION
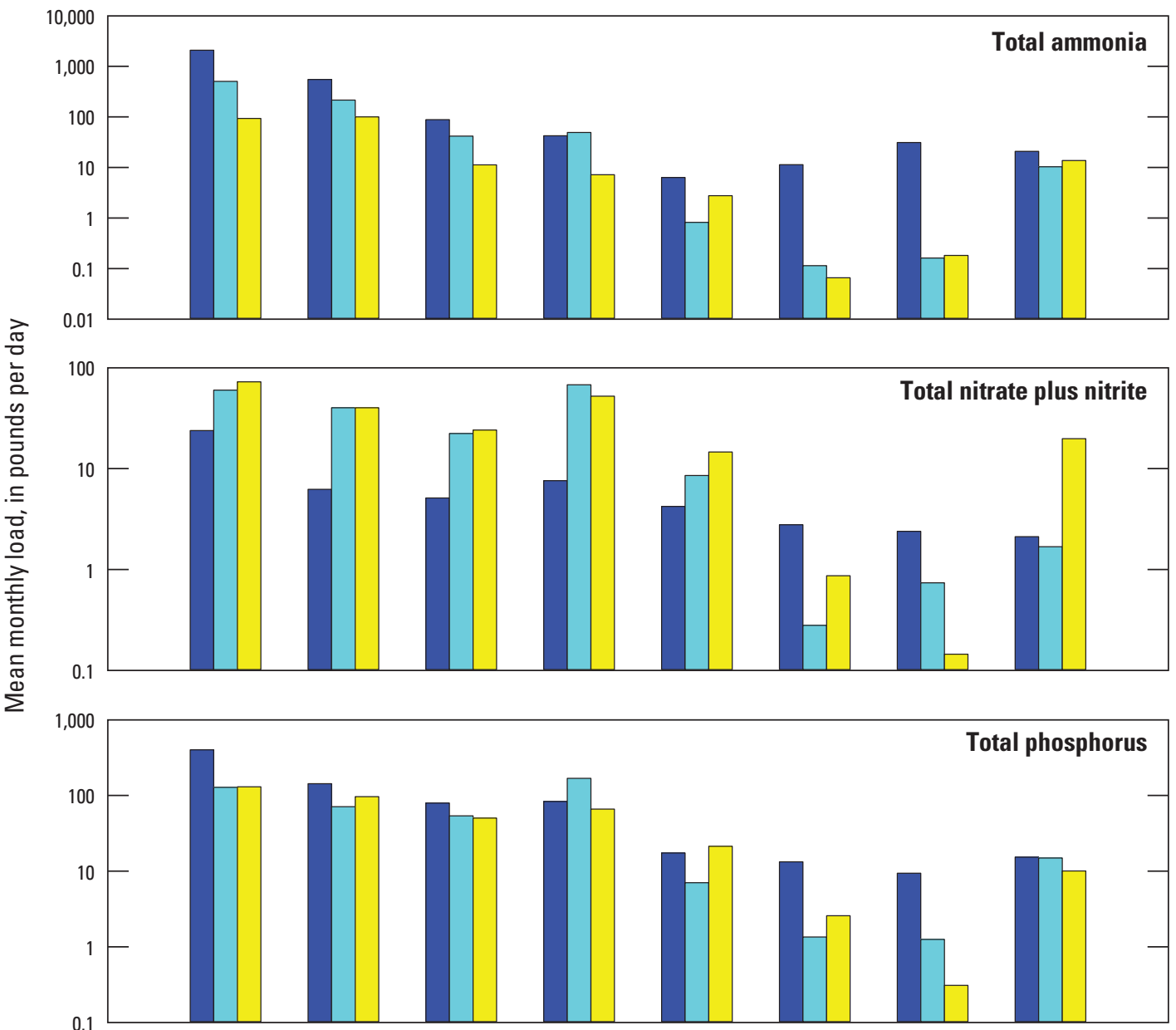

0.1



Figure 11. Mean monthly loads estimated for monitoring sites at Underwood farm, North Dakota, 2009-15. 
Table 9. Fertilizer application and crop information for Underwood farm, North Dakota, 2008-15.

[lb/yr, pound per year; $1 \mathrm{~b} / \mathrm{yr} / \mathrm{acre}$, pound per year per acre]

\begin{tabular}{cllcccc}
\hline Year & $\begin{array}{c}\text { Contributing area that } \\
\text { includes crop and } \\
\text { fertilizer application } \\
\text { estimate, } \\
\text { in acres }\end{array}$ & \multicolumn{1}{c}{ Crop } & $\begin{array}{c}\text { Estimated } \\
\text { nitrogen } \\
\text { application, } \\
\text { in lb/yr }\end{array}$ & $\begin{array}{c}\text { Estimated annual } \\
\text { nitrogen applica- } \\
\text { tion rate, } \\
\text { in lb/yr/acre }\end{array}$ & $\begin{array}{c}\text { Estimated } \\
\text { phosphorus } \\
\text { application, } \\
\text { in lb/yr }\end{array}$ & $\begin{array}{c}\text { Estimated annual } \\
\text { phosphorus } \\
\text { application rate, } \\
\text { in lb/yr/acre }\end{array}$ \\
\hline 2008 & 164 & Spring wheat/barley & 10,800 & 66 & 3,670 & 22 \\
2009 & 147 & Corn & 10,300 & 70 & 3,560 & 24 \\
2010 & 164 & Sunflowers & 11,000 & 67 & 5,120 & 31 \\
2011 & 164 & Spring wheat & 14,500 & 88 & 4,130 & 25 \\
2012 & 164 & Corn & 16,500 & 101 & 7,240 & 44 \\
2013 & 164 & Spring wheat/soybeans & 3,580 & 22 & 932 & 6 \\
2014 & 164 & Corn/spring wheat & 1,580 & 10 & 2,920 & 18 \\
2015 & 164 & Spring wheat/soybeans & 20,200 & 123 & 3,120 & 19 \\
\hline
\end{tabular}

ranged from less than $0.01 \mathrm{lb} / \mathrm{yr} / \mathrm{acre}$ at sites $\mathrm{U} 2$ and $\mathrm{U} 3$ in 2012 to $20 \mathrm{lb} / \mathrm{yr} / \mathrm{acre}$ as phosphorus at site $\mathrm{U} 1$ in 2011. Annual suspended-sediment yields ranged from $0.08 \mathrm{lb} / \mathrm{yr} / \mathrm{acre}$ at site U3 in 2012 to $802 \mathrm{lb} / \mathrm{yr} / \mathrm{acre}$ at site U1 in 2011 (fig. 12; table 8).

To put the contribution of flow and constituent loads into a larger-scaled context, the loads and yields for Underwood farm were compared to loads and yields estimated for a larger receiving stream in the area. The receiving stream for the drainage from Underwood farm is the Missouri River (fig. 1). Although Galloway and others (2012) estimated loads and yields for the Missouri River, the sites may not be a good comparison because they are in a highly regulated part of the river downstream from Garrison Dam (fig. 1). Instead, a smaller stream near Underwood, Spring Creek, was selected for comparison. Spring Creek is a tributary to the Knife River and ultimately the Missouri River (fig. 1). Normalized annual loads and yields were estimated for a site on Spring Creek at Zap, N. Dak. (USGS streamgage 06340000), that has a drainage area of 351,360 acres compared to a drainage area of 1,967 acres for site U3 (fig. 1 and table 10; Galloway and others, 2012). Normalized annual loads for Spring Creek for total ammonia, nitrate plus nitrite, and total phosphorus were $12,000 \mathrm{lb} / \mathrm{yr}$ as nitrogen, $18,000 \mathrm{lb} / \mathrm{yr}$ as nitrogen, and $10,000 \mathrm{lb} / \mathrm{yr}$ as phosphorus, respectively, compared to mean annual loads (2009-15) for site U3 at Underwood farm of $229 \mathrm{lb} / \mathrm{yr}$ as nitrogen, $232 \mathrm{lb} / \mathrm{yr}$ as nitrogen, and $387 \mathrm{lb} / \mathrm{yr}$ as phosphorus, respectively (table 10). Suspended-sediment loads estimated for Spring Creek were 4,080,000 lb/yr compared to a mean load of $7,700 \mathrm{lb} / \mathrm{yr}$ at site U3. Although loads were considerably less from site U3 compared to Spring Creek, mainly because of lower flow volume, nutrient yields were slightly greater but similar. For total ammonia, the normalized annual yield estimated for Spring Creek was $0.03 \mathrm{lb} / \mathrm{yr} / \mathrm{acre}$ as nitrogen, whereas the mean annual yield for site U3 was $0.12 \mathrm{lbs} / \mathrm{yr} / \mathrm{ac}$ as nitrogen (table 10). The normalized annual nitrate plus nitrite yield estimated for Spring Creek was $0.05 \mathrm{lb} / \mathrm{yr} / \mathrm{acre}$ as nitrogen, whereas the mean annual yield for site $\mathrm{U} 3$ was $0.12 \mathrm{lb} / \mathrm{yr} / \mathrm{acre}$ as nitrogen. The normalized annual total phosphorus yield estimated for Spring Creek was $0.03 \mathrm{lb} / \mathrm{yr} / \mathrm{acre}$, whereas the mean annual yield for site U3 was $0.20 \mathrm{lb} / \mathrm{yr} / \mathrm{acre}$. Suspended-sediment yields for Spring Creek were greater than mean annual yields for site U3 with a normalized annual yield of $12 \mathrm{lb} / \mathrm{yr} /$ acre compared to $3.9 \mathrm{lb} / \mathrm{yr} / \mathrm{acre}$ at site $\mathrm{U} 3$.

\section{Embden Farm}

At Embden farm from March 2009 through September 2016, about 44 samples were collected from site E1, 76 samples from site E2, and 123 samples from site E3. The number of values for individual constituents varied throughout the period because not all samples were analyzed for the same constituents (table 11). Runoff was sampled generally during spring snowmelt and rainfall events at the sites. In addition, at the two drainage tile sites (E2 and E3), samples were collected intermittently during periods of continuous flow (fig. 13).

\section{Concentrations}

Chloride concentrations measured at Embden farm were similar for the two drainage tile sites (E2 and E3) and were considerably higher than at the surface-water site (E1) (fig. 9). Likely sources of chloride at Embden farm are from the native soils and possibly shallow groundwater in the area. Site E1 had the lowest chloride concentrations with a median concentration that was less than the laboratory reporting limit of $3 \mathrm{mg} / \mathrm{L}$ (table 11). Concentrations were substantially greater at sites E2 and E3 with median concentrations of 15 and $19 \mathrm{mg} / \mathrm{L}$, respectively. The higher concentrations at sites E2 and E3 are likely from natural sources because these 


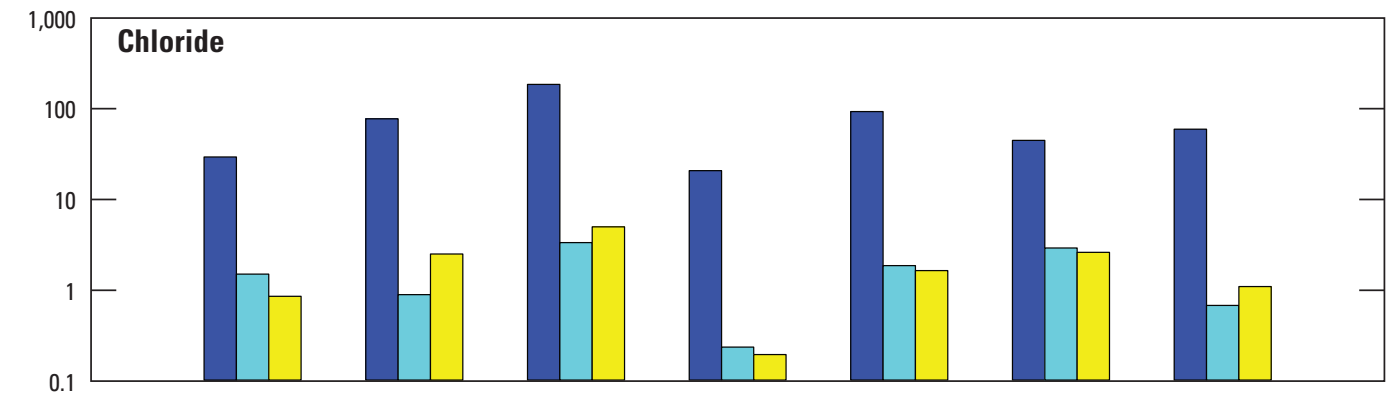

EXPLANATION

U1

$\square$ U2
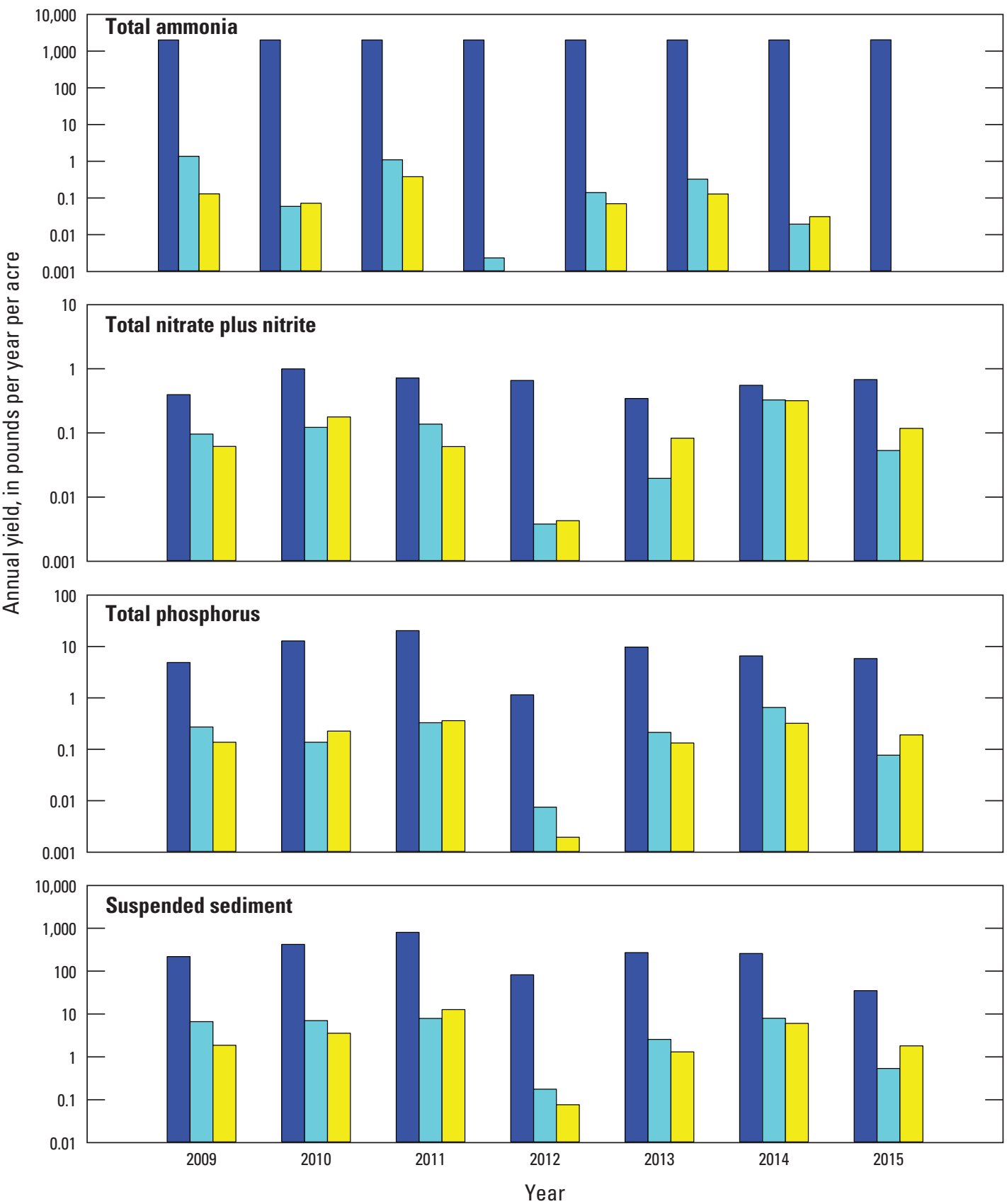

Figure 12. Annual yields estimated for monitoring sites at Underwood farm, North Dakota, 2009-15. 
Table 10. Loads and yields for selected sites from Galloway and others (2012) and Discovery Farms, North Dakota.

[--, not available $]$

\begin{tabular}{|c|c|c|c|c|c|c|c|c|c|c|}
\hline \multirow[b]{2}{*}{ Site name } & \multirow[b]{2}{*}{$\begin{array}{c}\text { Drainage } \\
\text { area, } \\
\text { in acres }\end{array}$} & \multirow[b]{2}{*}{$\begin{array}{l}\text { Load and yield } \\
\text { calculation }\end{array}$} & \multicolumn{4}{|c|}{ Load, in pound per year } & \multicolumn{4}{|c|}{ Yield, in pound per year per acre } \\
\hline & & & $\begin{array}{l}\text { Total } \\
\text { (unfiltered) } \\
\text { ammonia, } \\
\text { as N }\end{array}$ & $\begin{array}{c}\text { Total } \\
\text { (unfiltered) } \\
\text { nitrate plus } \\
\text { nitrite, } \\
\text { as N }\end{array}$ & $\begin{array}{c}\text { Total } \\
\text { (unfiltered) } \\
\text { phosphorus, } \\
\text { as P }\end{array}$ & $\begin{array}{l}\text { Suspended } \\
\text { sediment }\end{array}$ & $\begin{array}{c}\text { Total } \\
\text { (unfiltered) } \\
\text { ammonia, } \\
\text { as N }\end{array}$ & $\begin{array}{c}\text { Total } \\
\text { (unfiltered) } \\
\text { nitrate plus } \\
\text { nitrite, } \\
\text { as N }\end{array}$ & $\begin{array}{c}\text { Total } \\
\text { (unfiltered) } \\
\text { phosphorus, } \\
\text { as P }\end{array}$ & $\begin{array}{c}\text { Suspended } \\
\text { sediment }\end{array}$ \\
\hline $\begin{array}{l}\text { Spring Creek at } \\
\text { Zap, N. Dak. } \\
\text { (streamgage } \\
06340000 \text { ) } \\
\text { (fig. 1) }\end{array}$ & 351,360 & $\begin{array}{l}\text { Normalized annual } \\
\text { (Galloway and } \\
\text { others, 2012) }\end{array}$ & 12,000 & 18,000 & 10,000 & $4,080,000$ & 0.03 & 0.05 & 0.03 & 12 \\
\hline $\begin{array}{l}\text { Maple River below } \\
\text { Mapleton, N. Dak. } \\
\text { (streamgage } \\
05060100 \text { ) } \\
\text { (fig. 1) }\end{array}$ & 947,200 & $\begin{array}{l}\text { Normalized annual } \\
\text { (Galloway and } \\
\text { others, 2012) }\end{array}$ & 44,000 & $1,886,000$ & 14,000 & -- & 0.05 & 2.0 & 0.01 & -- \\
\hline $\begin{array}{l}\text { Baldhill Creek near } \\
\text { Dazey, N. Dak. } \\
\text { (streamgage } \\
05057200 \text { ) } \\
\text { (fig. 1) }\end{array}$ & 442,240 & $\begin{array}{l}\text { Normalized annual } \\
\text { (Galloway and } \\
\text { others, 2012) }\end{array}$ & 10,000 & 36,000 & 16,000 & -- & 0.02 & 0.08 & 0.04 & -- \\
\hline E1, E2, E3 (fig. 3) & 2371 & $\begin{array}{l}\text { Average of the an- } \\
\text { nual sum of sites } \\
\text { E1, E2, and E3 } \\
(2010-15)\end{array}$ & 43 & 3,130 & 26 & -- & 0.18 & 13 & 0.11 & -- \\
\hline D3 (fig. 4) & 341 & $\begin{array}{l}\text { Annual average } \\
(2010-15)\end{array}$ & 41 & 201 & 106 & 62,800 & 0.12 & 0.59 & 0.31 & 184 \\
\hline
\end{tabular}

${ }^{1}$ Drainage area includes surface drainage to site E1 (fig. 3, 164 acres) plus portion of field 1 not included in surface drainage, but contributing to site E2 (fig. 3,58 acres) plus portion of field 2 not included in surface drainage, but contributing to site E3 (fig. 3, 15 acres). 
Table 11. Summary of water-quality constituent concentrations for monitoring sites at Embden farm, North Dakota, 2009-16.

[Number in parentheses is the U.S. Geological Survey National Water Information System parameter code; $\mathrm{ft}^{3} / \mathrm{s}$, cubic foot per second; $\mu \mathrm{S} / \mathrm{cm}$ at $25^{\circ} \mathrm{C}$, microsiemen per centimeter at $25 \mathrm{degrees}$ Celsius; $\mathrm{mg} / \mathrm{L}$, milligram per liter; N, nitrogen; P, phosphorus, $<$, less than]

\begin{tabular}{|c|c|c|c|c|c|c|c|c|c|c|c|c|c|c|}
\hline $\begin{array}{l}\text { Site } \\
\text { (fig. 3) }\end{array}$ & Description & $\begin{array}{l}\text { Instan- } \\
\text { taneous } \\
\text { discharge, } \\
\text { in } \mathrm{ft}^{3} / \mathrm{s}\end{array}$ & $\begin{array}{l}\text { Specific } \\
\text { conduct- } \\
\text { ance, } \\
\text { laboratory, } \\
\mu \mathrm{S} / \mathrm{cm} \text { at } \\
25^{\circ} \mathrm{C}\end{array}$ & $\begin{array}{c}\text { Suspend- } \\
\text { ed solids, } \\
\text { in } \mathrm{mg} / \mathrm{L}\end{array}$ & $\begin{array}{c}\text { Chloride, } \\
\text { in } \mathrm{mg} / \mathrm{L}\end{array}$ & $\begin{array}{l}\text { Dissolved } \\
\text { (filtered) } \\
\text { ammonia, } \\
\text { in } \mathrm{mg} / \mathrm{L} \\
\text { as } \mathrm{N}\end{array}$ & $\begin{array}{c}\text { Total } \\
\text { (unfiltered) } \\
\text { ammonia, in } \\
\text { mg/L as } \mathbf{N}\end{array}$ & $\begin{array}{l}\text { Dissolved } \\
\text { (filtered) } \\
\text { nitrate plus } \\
\text { nitrite, in } \\
\mathrm{mg} / \mathrm{L} \text { as } \mathrm{N}\end{array}$ & $\begin{array}{l}\text { Total nitrate } \\
\text { plus nitrite } \\
\text { (unfiltered), p } \\
\text { in } \mathrm{mg} / \mathrm{L} \text { as } \mathrm{N} \text { i }\end{array}$ & $\begin{array}{l}\text { Dissolved } \\
\text { (filtered) } \\
\text { ohosphorus, } \\
\text { n mg/L as P }\end{array}$ & $\begin{array}{c}\text { Total } \\
\text { (unfiltered) } \\
\text { phosphorus, } \\
\text { in } \mathbf{m g} / \mathrm{L} \text { as } \mathrm{P}\end{array}$ & $\begin{array}{c}\text { Total } \\
\text { dissolved } \\
\text { (filtered) } \\
\text { nitrogen, in } \\
\mathrm{mg} / \mathrm{L} \text { as } \mathrm{N}\end{array}$ & $\begin{array}{c}\text { Total } \\
\text { (unfiltered) } \\
\text { nitrogen, in } \\
\text { mg/L as N }\end{array}$ & $\begin{array}{l}\text { Suspended- } \\
\text { sediment, } \\
\text { in } \mathrm{mg} / \mathrm{L}\end{array}$ \\
\hline & & (00061) & (90095) & (00530) & (00940) & (00608) & $(00610)$ & (00631) & (00630) & (00666) & (00665) & (62854) & (62855) & (80154) \\
\hline \multirow[t]{5}{*}{ E1 } & $\begin{array}{c}\text { Number of } \\
\text { samples }\end{array}$ & 34 & 44 & 44 & 43 & 24 & 39 & 24 & 39 & 24 & 39 & 24 & 39 & 26 \\
\hline & Minimum & 0.0 & 91 & $<5$ & $<3$ & $<0.03$ & $<0.03$ & $<0.03$ & $<0.03$ & 0.05 & 0.07 & 0.5 & 0.7 & 1 \\
\hline & Maximum & 1.8 & 311 & 104 & 18 & 2.4 & 2.4 & 2.0 & 2.1 & 2.2 & 2.2 & 7.9 & 9.2 & 123 \\
\hline & Median & 0.1 & 139 & $<5$ & $<3$ & 0.12 & 0.14 & 0.29 & 0.22 & 0.31 & 0.42 & 1.5 & 1.5 & 11 \\
\hline & Mean & 0.2 & 157 & 11 & 4 & 0.47 & 0.34 & 0.41 & 0.36 & 0.60 & 0.55 & 2.1 & 1.9 & 17 \\
\hline \multirow[t]{5}{*}{ E2 } & $\begin{array}{c}\text { Number of } \\
\text { samples }\end{array}$ & 75 & 76 & 75 & 76 & 52 & 73 & 55 & 73 & 55 & 75 & 53 & 73 & -- \\
\hline & Minimum & 0.0 & 168 & $<5$ & $<3$ & $<0.03$ & $<0.03$ & 0.23 & 0.25 & $<0.02$ & $<0.02$ & 1.7 & 1.8 & -- \\
\hline & Maximum & 2.2 & 941 & 72 & 40 & 2.0 & 2.0 & 17 & 18 & 1.5 & 1.6 & 27 & 27 & -- \\
\hline & Median & 0.3 & 797 & $<5$ & 15 & 0.05 & 0.05 & 12 & 13 & $<0.02$ & 0.03 & 12 & 13 & -- \\
\hline & Mean & 0.5 & 722 & 9 & 16 & 0.22 & 0.25 & 10 & 11 & 0.14 & 0.14 & 11 & 12 & -- \\
\hline \multirow[t]{5}{*}{ E3 } & $\begin{array}{c}\text { Number of } \\
\text { samples }\end{array}$ & 125 & 123 & 119 & 123 & 99 & 121 & 101 & 121 & 98 & 120 & 99 & 121 & -- \\
\hline & Minimum & 0.0 & 399 & $<5$ & 5 & $<0.03$ & $<0.03$ & 0.60 & 0.59 & $<0.02$ & $<0.02$ & 1.9 & 2.3 & -- \\
\hline & Maximum & 2.5 & 1,100 & 60 & 41 & 2.2 & 2.0 & 19 & 19 & 0.60 & 0.68 & 23 & 23 & -- \\
\hline & Median & 0.2 & 889 & $<5$ & 19 & $<0.03$ & $<0.03$ & 9.8 & 10 & $<0.02$ & 0.03 & 10 & 11 & -- \\
\hline & Mean & 0.6 & 883 & 6 & 19 & 0.15 & 0.17 & 9.7 & 10 & 0.06 & 0.07 & 11 & 11 & -- \\
\hline
\end{tabular}



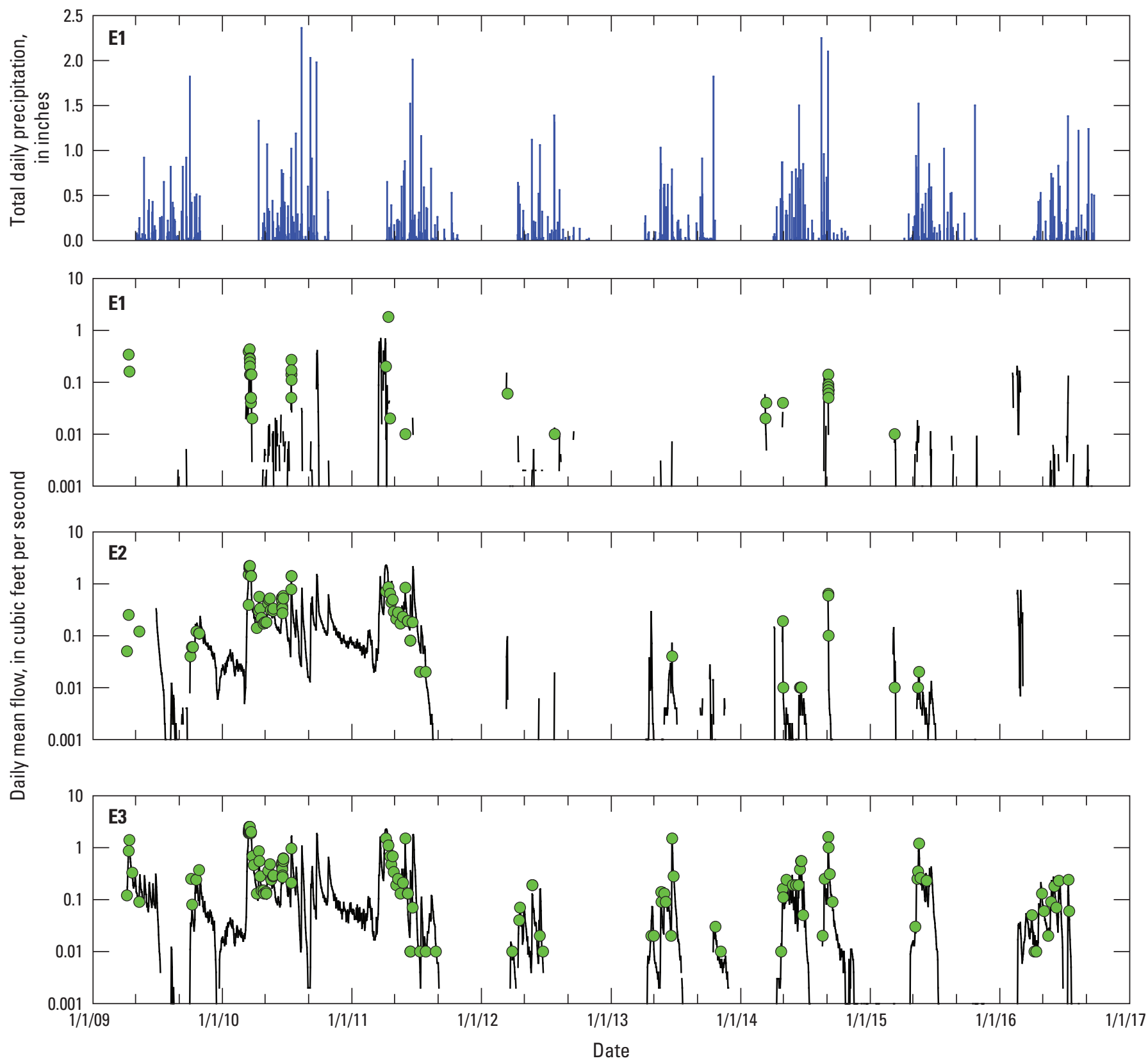

EXPLANATION

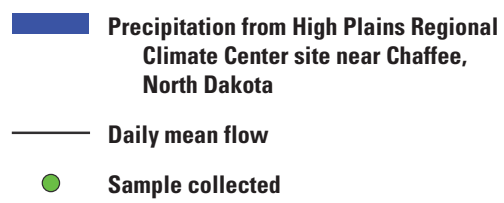

Figure 13. Daily mean flow, daily precipitation, and samples collected at monitoring sites at Embden farm, North Dakota, 2009-16.

sites represent water that has infiltrated through the soil and can dissolve naturally-occurring chlorides in the soils. During extended wet periods when groundwater levels are high, sites E2 and E3 can receive water that has had long contact time with aquifer material that may contain chlorides and are discharged through the drainage tile. Groundwater quality was not measured in the area, so the effects of groundwater contribution to the drainage tile sites could not be definitively determined. 
Nutrient concentrations generally were similar for the drainage tile sites E2 and E3; concentrations of total ammonia and total phosphorus were lower and concentrations of total nitrate plus nitrite were higher compared to the surface water site E1 (fig. 9). Potential sources of nutrients related to agricultural activities include fertilizer applications to the surrounding cropland. Although there is a cattle operation at Embden farm, it is not within the area contributing to runoff at the three monitoring sites. There was some application of manure to fields just north of site E3 (field 2, fig. 3) in 2012 that could also be a source of nutrients to the site. Total ammonia and phosphorus concentrations at the sites for Embden farm were generally lower than measured at Underwood and Dazey farms (fig. 9). Median total ammonia concentrations at sites E1, E2, and E3 were 0.14, 0.05, and less than $0.03 \mathrm{mg} / \mathrm{L}$ as nitrogen, respectively. Median total phosphorus concentrations at sites E1, E2, and E3 were $0.42,0.03$, and $0.03 \mathrm{mg} / \mathrm{L}$ as phosphorus, respectively (table 11).

Nitrate plus nitrite concentrations were lowest at site E1 and highest at sites E2 and E3. Nitrate plus nitrite concentration at sites E2 and E3 also were the highest among all the sites at all three farms (fig. 9). Median total nitrate plus nitrite concentrations for sites E1, E2, and E3 were 0.22, 13, and $10 \mathrm{mg} / \mathrm{L}$ as nitrogen, respectively (table 11). Nitrate plus nitrite has been found to be higher in drain tiles because runoff can readily transport nitrates that were applied as fertilizer into the subsurface before the nitrates can be processed by vegetation on the surface and can be leeched from the soil as the water travels into the drain tiles (U.S. Environmental Protection Agency, 2015).

Suspended sediment was measured only at site E1 because of little sediment content in the drainage tiles that are measured by sites E2 and E3, and concentrations at site E1 were the lowest among all the sites at all three farms (fig. 9). The median concentration of suspended sediment at site E1 was $11 \mathrm{mg} / \mathrm{L}$ (table 11). Suspended-sediment concentrations at site E1 were probably lowest compared to sites at the other farms because the area has relatively flat terrain with little slope compared to all the other sites; therefore, there is less energy to move soil material during runoff.

\section{Loads and Yields}

Annual loads (March through October) were estimated at Embden farm for 2010-15 at sites E1 and E2 and for 2010-16 at site E3 (fig. 14; table 12). Annual loads were considerably greater at sites E2 and E3 compared to site E1. Annual loads for chloride at all three sites were the greatest in 2010 and 2011 and the least in 2012 or 2013, which coincided with years of the greatest and least annual flow volume, respectively (tables 5 and 12). Also, as described in the "Runoff and Flow Characteristics" section, sites E2 and E3 had nearly continuous flow in the drainage tiles throughout 2010 and 2011, providing transport of constituents throughout that period resulting in large annual loads, whereas site E1 only had flow to transport material during spring snowmelt or rainfall events. Annual loads also were similar between sites E2 and E3 in 2010 and 2011, but in subsequent years, site E3 generally had the greatest annual load among the three sites for all constituents. Annual chloride loads ranged from less than 1 to $193 \mathrm{lb} / \mathrm{yr}$ at site E1, from 16 to 6,700 lb/yr at site E2, and from 210 to 9,380 lb/yr at site E3 (fig. 14; table 12). Total ammonia loads were greatest at site E3 most years except for 2011 and 2013, when site E2 had the greatest load among the three sites, and 2012, when site E1 had the greatest load. Annual total ammonia loads ranged from less than 1 to $3 \mathrm{lb} / \mathrm{yr}$ as nitrogen at site E1, from less than 1 to $79 \mathrm{lb} / \mathrm{yr}$ as nitrogen at site E2, and from less than 1 to $89 \mathrm{lb} / \mathrm{yr}$ as nitrogen at site E3 (fig. 14; table 12).

Nitrate plus nitrite loads were greatest at sites E2 and E3, and the greatest annual loads were in 2010 and 2011. Sites E2 and E3 had similar annual loads in 2010 and 2011, but site E3 had the greatest annual nitrate plus nitrite loads in subsequent years (fig. 14; table 12). Annual nitrate plus nitrite loads ranged from less than 1 to $15 \mathrm{lb} / \mathrm{yr}$ as nitrogen at site E1, from 8 to 5,050 lb/yr as nitrogen at site E2, and from 125 to $4,720 \mathrm{lb} / \mathrm{yr}$ as nitrogen at site E3 (fig. 14; table 12). Annual total phosphorus loads were greatest in 2010 and 2011 at all three sites. Annual total phosphorus loads ranged from 0.12 to $5.8 \mathrm{lb} / \mathrm{yr}$ as phosphorus at site E1, from less than 0.10 to $39 \mathrm{lb} / \mathrm{yr}$ as phosphorus at site E2, and from 0.53 to $28 \mathrm{lb} / \mathrm{yr}$ as phosphorus at site E3 (fig. 14; table 12).

Some of the patterns in annual load could be explained by crop management and fertilizer application in the fields that contribute runoff to the three sites. Crop type and fertilizer application information for field 1 and field 2 that drain to the three Embden sites was provided by the producer for each year from 2010 to 2015 (tables 13 and 14, respectively). To estimate the amount of nutrients being exported from each field, the following assumptions were made: (1) the sum of the total ammonia and nitrate plus nitrite represented the total nitrogen export, (2) total phosphorus load represented phosphorus export, and (3) nutrients applied were either exported through the two drainage tile sites (E2 or E3) or through surface runoff through site E1. Based on the last assumption, a percentage of the annual load for each site can be attributed to nutrient export for a specific field. For field 1 (fig. 3), 13 percent of the surface drainage area for site E1 and 100 percent of the tile drainage area for site E2 contributes to the export of nutrients; therefore, 13 percent of the load for site E1 plus the total load for site E2 were used to represent the total load exported from field 1. For field 2 (fig. 3), 34 percent of the surface drainage area for site E1 and 100 percent of the tile drainage area for site E3 contributes to nutrient export; therefore, 34 percent of the load for site E1 plus the total load for site E3 were used to represent the total load exported from field 2. At the Embden farm, depending on hydrologic conditions, groundwater may be contributing to the amount of nutrients exported through the drainage tile sites. Because groundwater effects on nutrient export could not be quantified, a ratio was used instead of a percentage to compare exported to applied nutrients. 



Figure 14. Annual loads estimated for monitoring sites at Embden farm, North Dakota, 2010-16. 
Table 12. Annual loads and yields for Embden farm, North Dakota, 2010-16.

$[\mathrm{N}$, nitrogen; $\mathrm{P}$, phosphorus, $<$, less than $]$

\begin{tabular}{|c|c|c|c|c|c|c|c|c|c|}
\hline \multirow[b]{2}{*}{ Year } & \multirow[b]{2}{*}{$\begin{array}{l}\text { Flow, in } \\
\text { acre-feet } \\
\text { per year }\end{array}$} & \multicolumn{4}{|c|}{ Load, in pounds per year } & \multicolumn{4}{|c|}{ Yield, in pounds per year per acre } \\
\hline & & Chloride & $\begin{array}{c}\text { Total } \\
\text { (unfiltered) } \\
\text { ammonia, } \\
\text { as N }\end{array}$ & $\begin{array}{c}\text { Total } \\
\text { (unfiltered) } \\
\text { nitrate plus } \\
\text { nitrite, as } \mathbf{N}\end{array}$ & $\begin{array}{c}\text { Total } \\
\text { (unfiltered) } \\
\text { phosphorus, } \\
\text { as P }\end{array}$ & Chloride & $\begin{array}{c}\text { Total } \\
\text { (unfiltered) } \\
\text { ammonia, } \\
\text { as N }\end{array}$ & $\begin{array}{c}\text { Total } \\
\text { (unfiltered) } \\
\text { nitrate plus } \\
\text { nitrite, as } \mathbf{N}\end{array}$ & $\begin{array}{c}\text { Total } \\
\text { (unfiltered) } \\
\text { phosphorus, } \\
\text { as P }\end{array}$ \\
\hline \multicolumn{10}{|c|}{ Site E1 } \\
\hline 2010 & 7 & 193 & 1 & 9 & 4.1 & 1.2 & 0.01 & 0.06 & 0.03 \\
\hline 2012 & $<1$ & 8 & 2 & $<1$ & 4.0 & 0.05 & 0.01 & $<0.01$ & 0.02 \\
\hline 2013 & $<1$ & $<1$ & $<1$ & $<1$ & 0.12 & $<0.01$ & $<0.01$ & $<0.01$ & $<0.01$ \\
\hline 2014 & $<1$ & 15 & 2 & 1 & 2.0 & 0.09 & 0.01 & 0.01 & 0.01 \\
\hline 2015 & $<1$ & 9 & 3 & $<1$ & 2.7 & 0.05 & 0.02 & $<0.01$ & 0.02 \\
\hline 2011 & 128 & 4,150 & 17 & 3,410 & 39 & 52 & 0.21 & 43 & 0.48 \\
\hline 2012 & $<1$ & 16 & $<1$ & 21 & $<0.10$ & 0.20 & $<0.01$ & 0.26 & $<0.01$ \\
\hline 2013 & 2 & 28 & 5 & 15 & 5.4 & 0.35 & 0.06 & 0.18 & 0.07 \\
\hline 2014 & 3 & 39 & 3 & 14 & 3.9 & 0.49 & 0.04 & 0.17 & 0.05 \\
\hline 2015 & 1 & 36 & 5 & 8 & 4.0 & 0.45 & 0.06 & 0.09 & 0.05 \\
\hline Mean & 46 & 1,830 & 18 & 1,420 & 11 & 23 & 0.23 & 18 & 0.14 \\
\hline \multicolumn{10}{|c|}{ Site E3 } \\
\hline 2010 & 158 & 9,380 & 89 & 4,720 & 11 & 134 & 1.3 & 67 & 0.15 \\
\hline 2011 & 126 & 4,480 & 12 & 3,040 & 28 & 64 & 0.17 & 43 & 0.40 \\
\hline
\end{tabular}

Ratios of exported to applied nitrogen were greatest for both fields in 2010 and 2011, which corresponds to the years of the greatest runoff for all three sites (tables 5, 13, and 14). For field 1, the ratio of exported to applied nitrogen was 0.56 in 2010 and 0.84 in 2011 (table 13). The ratios indicate that about 44 percent of the nitrogen applied potentially was retained in the soil or used by crops in 2010 and 16 percent potentially was retained in 2011 . In subsequent years (2012-15), the ratios were much less, ranging from 0.01 to 0.03 , indicating greater than 97 percent of the applied nitrogen potentially was retained. For field 2 , the ratio of exported to applied nitrogen was 0.49 in 2010 and 0.71 in 2011 (table 14). Similar to field 1, the ratios were less in 2013 and 2014 with ratios of 0.20 and 0.18 , respectively, but these ratios were not as low as the corresponding values from field 1 during the same period. During the wet years of 2010 and 2011, it is probable that the amount of fertilizer applied to fields 1 and 2 did not account for all nitrogen sources to the three sites. It is likely that groundwater contributed to the nitrogen exported through the drainage tile sites E2 and E3 compared to subsequent years.

The difference in exported and applied nitrogen ratios between fields 1 and 2 for 2013 and 2014 may be, in part, due to differences in crop management for the two fields. The amount of fertilizer applied did not seem to explain the larger amounts of nitrogen exported from field 2 because some of the highest application rates were in 2012 and 2015 (8,890 and $11,800 \mathrm{lb} / \mathrm{yr}$, respectively); yet the ratios of exported nitrogen were lowest in 2012 and 2015 for field 2. Field 2 had 3,140 lb/yr of nitrogen applied and corn and soybeans planted in 2013, and 5,050 lb/yr of nitrogen applied and spring wheat planted in 2014 (table 14). For field 1, only $581 \mathrm{lb} / \mathrm{yr}$ of 
[N, nitrogen; P, phosphorus; --, not available]

\begin{tabular}{|c|c|c|c|c|c|c|c|c|c|}
\hline \multirow[b]{2}{*}{ Year } & \multicolumn{2}{|c|}{$\begin{array}{l}\text { Annual loads for site E1 } \\
\text { (13 percent of total load) plus } \\
\text { site E2, in pounds per year }\end{array}$} & \multicolumn{7}{|c|}{ Field (field 1; fig. 3) that contributes runoff to site E1 (13 percent of total drainage) and site E2 } \\
\hline & $\begin{array}{l}\text { Total ammonia } \\
\text { and nitrate } \\
\text { plus nitrite, } \\
\text { as } \mathbf{N}\end{array}$ & $\begin{array}{l}\text { Total } \\
\text { phosphorus, } \\
\text { as } \mathbf{P}\end{array}$ & $\begin{array}{c}\text { Estimated } \\
\text { nitrogen } \\
\text { application, } \\
\text { in pounds per } \\
\text { year }\end{array}$ & $\begin{array}{l}\text { Estimated annual } \\
\text { nitrogen applica- } \\
\text { tion rate, in pounds } \\
\text { per acre per year }\end{array}$ & $\begin{array}{l}\text { Estimated } \\
\text { phosphorus } \\
\text { application, in } \\
\text { pounds per year }\end{array}$ & $\begin{array}{l}\text { Estimated annual } \\
\text { phosphorus } \\
\text { application rate, } \\
\text { in pounds per } \\
\text { acre per year }\end{array}$ & $\begin{array}{l}\text { Ratio of exported } \\
\text { nitrogen } \\
\text { (ammonia, nitrate, } \\
\text { and nitrite) to } \\
\text { applied nitrogen as } \\
\text { fertilizer }\end{array}$ & $\begin{array}{l}\text { Ratio of exported } \\
\text { phosphorus to } \\
\text { applied phosphorus } \\
\text { as fertilizer }\end{array}$ & Crop type \\
\hline 2010 & 5,130 & 16 & 9,240 & 140 & -- & -- & 0.56 & -- & Corn silage/soybeans. \\
\hline 2011 & 3,430 & 39 & 4,100 & 62 & 1,410 & 21 & 0.84 & 0.028 & Spring wheat. \\
\hline 2012 & 22 & 1 & 632 & 10 & 2,990 & 45 & 0.03 & $<0.001$ & Alfalfa. \\
\hline 2013 & 19 & 5 & 581 & 9 & 2,750 & 42 & 0.03 & 0.003 & Alfalfa. \\
\hline 2014 & 17 & 4 & 726 & 11 & 3,430 & 52 & 0.02 & 0.001 & Alfalfa. \\
\hline 2015 & 13 & 4 & 908 & 14 & 4,290 & 65 & 0.01 & 0.001 & Alfalfa. \\
\hline
\end{tabular}

Table 14. Estimate of exported and applied nutrients, ratio of exported to applied nutrients and crop type for field 2 at Embden farm, North Dakota, $2010-15$.

[N, nitrogen; P, phosphorus; --, not available]

\begin{tabular}{|c|c|c|c|c|c|c|c|c|c|}
\hline \multirow[b]{2}{*}{ Year } & \multicolumn{2}{|c|}{$\begin{array}{l}\text { Annual loads for site E1 } \\
\text { (34 percent of total load) plus } \\
\text { site E3, in pounds per year }\end{array}$} & \multicolumn{7}{|c|}{ Field (field 2; fig. 3) that contributes runoff to site E1 (34 percent of total drainage) and site E3 } \\
\hline & $\begin{array}{c}\text { Total } \\
\text { ammonia and } \\
\text { nitrate } \\
\text { plus nitrite, } \\
\text { as } \mathrm{N}\end{array}$ & $\begin{array}{l}\text { Total } \\
\text { phosphorus, } \\
\text { as } \mathbf{P}\end{array}$ & $\begin{array}{l}\text { Estimated } \\
\text { nitrogen } \\
\text { application, } \\
\text { in pounds } \\
\text { per year }\end{array}$ & $\begin{array}{c}\text { Estimated annual } \\
\text { nitrogen applica- } \\
\text { tion rate, } \\
\text { in pounds per } \\
\text { acre per year }\end{array}$ & $\begin{array}{l}\text { Estimated } \\
\text { phosphorus } \\
\text { application, } \\
\text { in pounds } \\
\text { per year }\end{array}$ & $\begin{array}{l}\text { Estimated annual } \\
\text { phosphorus ap- } \\
\text { plication rate, } \\
\text { in pounds per } \\
\text { acre per year }\end{array}$ & $\begin{array}{c}\text { Ratio of exported } \\
\text { nitrogen (ammonia, } \\
\text { nitrate, and nitrite) to } \\
\text { applied nitrogen as } \\
\text { fertilizer }\end{array}$ & $\begin{array}{l}\text { Ratio of exported } \\
\text { phosphorus to } \\
\text { applied phosphorus } \\
\text { as fertilizer }\end{array}$ & Crop type \\
\hline 2010 & 4,810 & 12 & 9,800 & 140 & -- & -- & 0.49 & -- & Corn silage/soybeans. \\
\hline 2011 & 3,060 & 30 & 4,340 & 62 & 1,500 & 21 & 0.71 & 0.020 & Spring wheat. \\
\hline 2012 & 127 & 2 & 8,890 & 127 & 3,170 & 45 & 0.01 & $<0.001$ & Corn. \\
\hline 2013 & 641 & 9 & 3,140 & 45 & 2,150 & 31 & 0.20 & 0.004 & Corn/soybeans. \\
\hline 2014 & 886 & 14 & 5,050 & 72 & 2,180 & 31 & 0.18 & 0.006 & Spring wheat. \\
\hline 2015 & 843 & 7 & 11,800 & 169 & 2,670 & 38 & 0.07 & 0.003 & Corn. \\
\hline
\end{tabular}


nitrogen was applied in 2013 and $726 \mathrm{lb} / \mathrm{yr}$ of nitrogen applied in 2014, and alfalfa was planted in the field both years. It seems that the combination of lower application rates, subsequent years of planting alfalfa compared to the other crop rotation, and the amount of annual runoff may have affected the amount of nitrogen exported at Embden farm.

The ratio of exported phosphorus to applied phosphorus was highest in 2011 (fertilizer application data for 2010 were not available), lower in subsequent years, and much less than the ratios for nitrogen. For fields 1 and 2, the ratios in 2011 were 0.028 and 0.020 , respectively. For subsequent years, the ratios were all less than or equal to 0.006 (tables 13 and 14).

Mean monthly loads indicated different patterns depending on the sites and the constituents at the Embden farm sites (fig. 15). For sites E1 and E2, most of the annual load for all constituents was transported in March and April when most of the snowmelt and rainfall runoff occurs. At site E3, the chloride load was greatest in March, June, and January on average; however, the greater loads for several constituents in the winter months (December, January, and February) only were in 2010 and 2011 (fig. 15; appendix table 1-4) when there was flow at the site. The total ammonia load at site E3 was greatest in February and May on average. The nitrate plus nitrite load was greatest in February and June, on average, with a large part also delivered in March and April (fig. 15). The total phosphorus load was greatest in May and June, on average, when most of the planting and fertilizer application occurred. In general, most of the nutrient loads were delivered when there was greater precipitation and associated runoff and little vegetative growth for uptake of nutrients. The difference in the pattern of monthly loads between sites E2 and E3 may be due to the variety of crops planted in fields that contributed to the two sites. The loads for all constituents at site E2 were greatest in March and April, and field 1, which contributes to site E2, was planted with corn silage and soybeans in 2010, spring wheat in 2011, and alfalfa in 2012-15 (fig. 15; table 13). At site E3, loads varied depending on constituent, but many of the nutrients were either greatest in the later months of May and June or in February (only in 2010 and 2011; appendix table 1-4). Field 2 (that contributes flow to site E3) had rotational planting of corn, soybeans, and spring wheat throughout 2010-15 (table 14). Although a direct correlation between crop type and load is not possible, the crop type seems to have affected when nutrients are transported at the site on a monthly and annual basis.

Annual yields were computed for the three sites for comparison of the sites in terms of how much mass of the constituents are transported past each site per acre contributing runoff to each site (fig. 16). Annual yields for all constituents were substantially greater at sites E2 and E3 compared to site E1, mainly because of a combination of higher flow volumes and small contributing drainage areas at sites E2 and E3 compared to site E1. Sites E2 and E3 had generally similar annual yields for all constituents in 2010 and 2011, and site E3 generally had the highest yield among the three sites in subsequent years. Annual chloride yields ranged from less than 0.01 to $1.2 \mathrm{lb} / \mathrm{yr} / \mathrm{acre}$ at site E1, 0.20 to $84 \mathrm{lb} / \mathrm{yr} / \mathrm{acre}$ at site E2, and 3.0 to $134 \mathrm{lb} / \mathrm{yr} /$ acre at site E3 (fig. 16; table 12). Annual total ammonia yields ranged from less than 0.01 to $0.02 \mathrm{lb} / \mathrm{yr} / \mathrm{acre}$ as nitrogen at site E1, less than 0.01 to $0.98 \mathrm{lb} / \mathrm{yr} / \mathrm{acre}$ as nitrogen at site E2, and less than 0.01 to $1.3 \mathrm{lb} / \mathrm{yr} / \mathrm{acre}$ as nitrogen at site E3. Annual total nitrate plus nitrite yields ranged from less than 0.01 to $0.09 \mathrm{lb} / \mathrm{yr} / \mathrm{acre}$ as nitrogen at site $\mathrm{E} 1,0.09$ to $63 \mathrm{lb} / \mathrm{yr} / \mathrm{acre}$ as nitrogen at site E2, and 1.8 to $67 \mathrm{lb} / \mathrm{yr} /$ acre as nitrogen at site E3 (fig. 16; table 12). Annual total phosphorus yields ranged from less than 0.01 to $0.04 \mathrm{lb} / \mathrm{yr} /$ acre as phosphorus at site E1, less than 0.01 to $0.48 \mathrm{lb} / \mathrm{yr} / \mathrm{acre}$ as phosphorus at site E2, and less than 0.01 to $0.40 \mathrm{lb} / \mathrm{yr} / \mathrm{acre}$ as phosphorus at site $\mathrm{E} 3$.

To put the contribution of flow and constituent loads into a larger-scaled context, the loads and yields for Embden farm were compared to loads and yields estimated for the Maple River. The nearest site with estimated annual loads and yields from Galloway and others (2012) is below Mapleton, N. Dak, and has a drainage area of 947,200 acres (fig. 1 and table 10; USGS streamgage 05060100). The site is about 60 river miles downstream from the confluence of the drainage from Embden farm that has a total drainage of about 164 acres (table 10). Normalized annual loads for the Maple River below Mapleton for total ammonia, nitrate plus nitrite, and total phosphorus were $44,000 \mathrm{lb} / \mathrm{yr}$ as nitrogen, 1,886,000 $\mathrm{lb} / \mathrm{yr}$ as nitrogen, and $14,000 \mathrm{lb} / \mathrm{yr}$ as phosphorus, respectively (table 10). In comparison, mean annual loads estimated for the total drainage from Embden farm (mean of the annual sum of loads for E1, E2, and E3 for 2010 through 2015; table 12) for total ammonia, nitrate plus nitrite, and total phosphorus were $43 \mathrm{lb} / \mathrm{yr}$ as nitrogen, 3,130 lb/yr as nitrogen, and $26 \mathrm{lb} / \mathrm{yr}$ as phosphorus, respectively (table 10). Nutrient loads from the drainage at Embden farm represents less than 0.2 percent of the nutrient loads estimated for the receiving stream, the Maple River. Although loads were considerably less from the Embden farm drainage compared to the Maple River, nitrate plus nitrite yields were much greater, and total ammonia and total phosphorus yields were slightly greater but similar to the Maple River. For total ammonia, the normalized annual yield estimated for the Maple River was $0.05 \mathrm{lb} / \mathrm{yr} / \mathrm{acre}$ as nitrogen, whereas the mean annual yield for the Embden farm sites was $0.18 \mathrm{lb} / \mathrm{yr} /$ acre as nitrogen. The normalized annual nitrate plus nitrite yield estimated for the Maple River was $2.0 \mathrm{lb} / \mathrm{yr} / \mathrm{acre}$ as nitrogen, whereas the mean annual yield for the sum of the three sites at Embden was $13 \mathrm{lb} / \mathrm{yr} /$ acre as nitrogen (table 10). The normalized annual total phosphorus yield estimated for the Maple River was $0.01 \mathrm{lb} / \mathrm{yr} / \mathrm{acre}$ as phosphorus, whereas the mean annual yield for the Embden sites was $0.11 \mathrm{lb} / \mathrm{yr} /$ acre as phosphorus (table 10). 

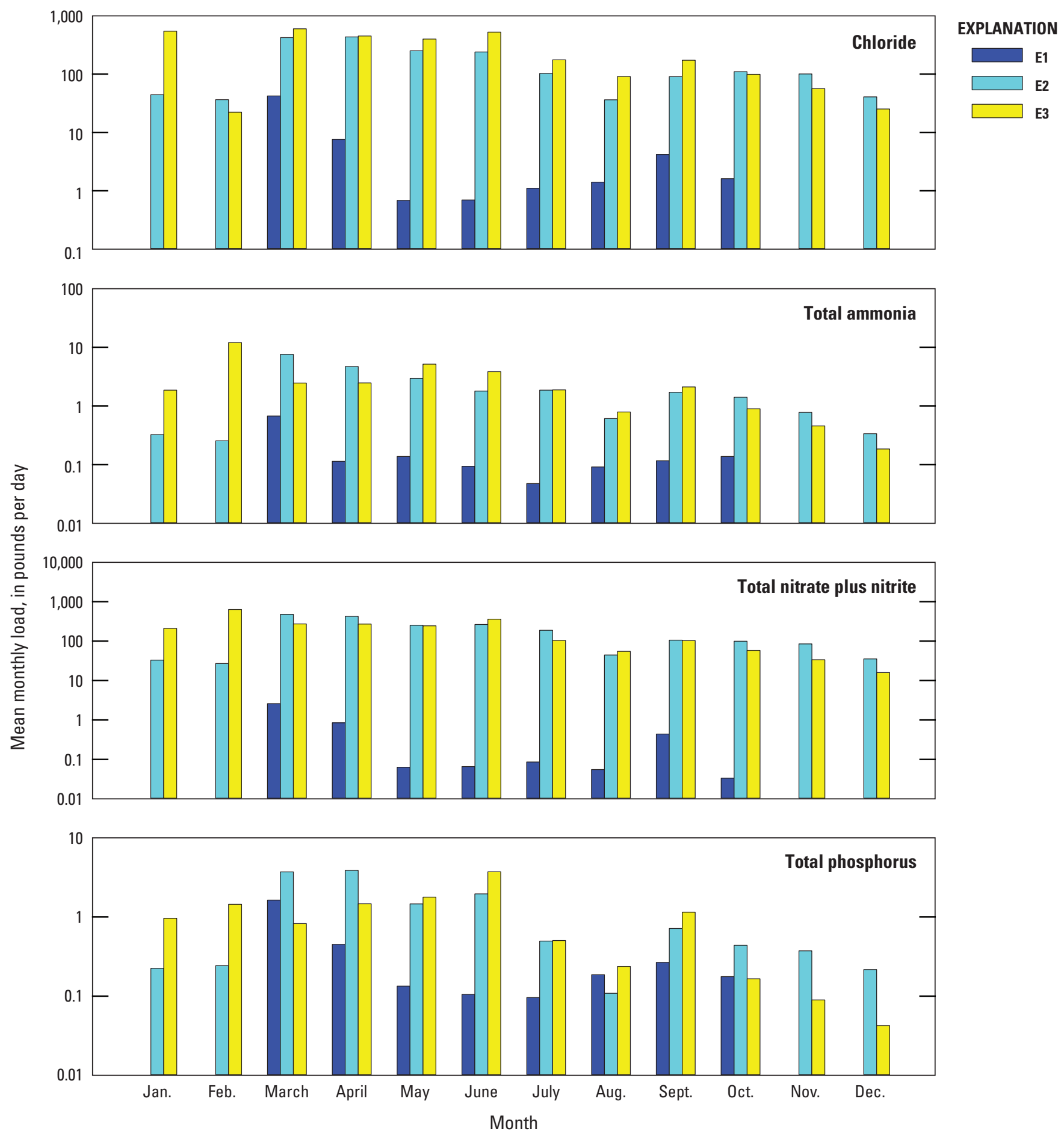

Figure 15. Monthly loads estimated for monitoring sites at Embden farm, North Dakota, 2010-16. 


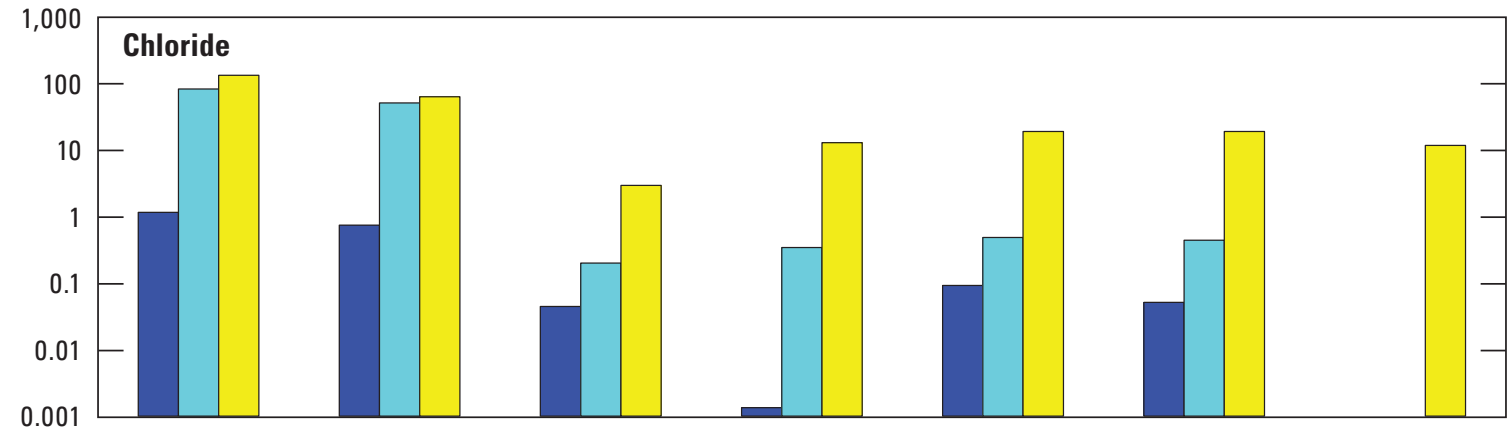

EXPLANATION

E1 $\square$ E2 $\square$ E3
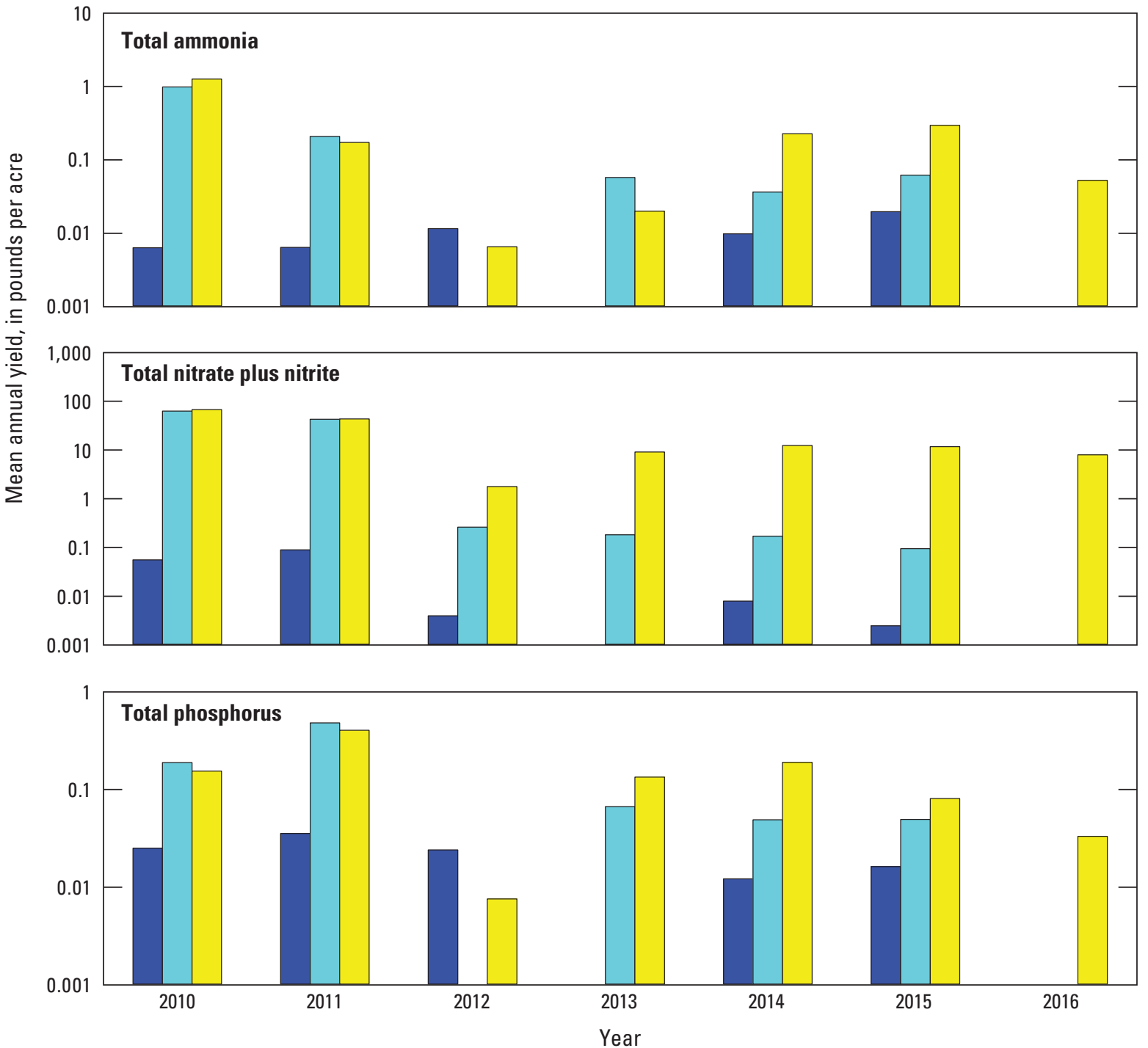

Figure 16. Annual yields estimated for monitoring sites at Underwood farm, North Dakota, 2009-15. 
Table 15. Summary of water-quality constituent concentrations for monitoring sites at Dazey farm, North Dakota, 2008-15.

[Number in parentheses is the U.S. Geological Survey National Water Information System parameter code; $\mathrm{ft}^{3} / \mathrm{s}$, cubic foot per second; $\mu \mathrm{S} / \mathrm{cm}$ at $25^{\circ} \mathrm{C}$, microsiemen per centimeter at $25 \mathrm{degrees}$ Celsius; $\mathrm{mg} / \mathrm{L}$, milligram per liter; N, nitrogen; $\mathrm{P}$, phosphorus; $<$, less than]

\begin{tabular}{|c|c|c|c|c|c|c|c|c|c|c|c|c|c|c|}
\hline $\begin{array}{c}\text { Site } \\
\text { (fig. 4) }\end{array}$ & Description & $\begin{array}{l}\text { Instan- } \\
\text { taneous } \\
\text { discharge, } \\
\text { in } \mathrm{ft}^{3} / \mathrm{s}\end{array}$ & $\begin{array}{c}\text { Specific } \\
\text { conduct- } \\
\text { ance, } \\
\text { laboratory, } \\
\mu \mathrm{S} / \mathrm{cm} \text { at } \\
25^{\circ} \mathrm{C}\end{array}$ & $\begin{array}{c}\text { Suspended } \\
\text { solids, } \\
\text { in } \mathrm{mg} / \mathrm{L}\end{array}$ & $\begin{array}{l}\text { Chloride, } \\
\text { in } \mathrm{mg} / \mathrm{L}\end{array}$ & $\begin{array}{l}\text { Dissolved } \\
\text { (filtered) } \\
\text { ammonia, } \\
\text { in } \mathrm{mg} / \mathrm{L} \\
\text { as } \mathrm{N}\end{array}$ & $\begin{array}{c}\text { Total } \\
\text { (unfiltered) } \\
\text { ammonia, } \\
\text { in } \mathrm{mg} / \mathrm{L} \\
\text { as } \mathrm{N}\end{array}$ & $\begin{array}{l}\text { Dissolved } \\
\text { (filtered) } \\
\text { nitrate plus } \\
\text { nitrite, in } \\
\mathrm{mg} / \mathrm{L} \text { as } \mathrm{N}\end{array}$ & $\begin{array}{c}\text { Total } \\
\text { nitrate } \\
\text { plus nitrite } \\
\text { (unfiltered), } \\
\text { in } \mathrm{mg} / \mathrm{L} \\
\text { as } \mathrm{N}\end{array}$ & $\begin{array}{l}\text { Dissolved } \\
\text { (filtered) } \\
\text { phosphorus, } \\
\text { in } \mathrm{mg} / \mathrm{L} \\
\text { as } \mathrm{P}\end{array}$ & $\begin{array}{c}\text { Total } \\
\text { (unfiltered) } \\
\text { phosphorus, } \\
\text { in } \mathrm{mg} / \mathrm{L} \\
\text { as } \mathrm{P}\end{array}$ & $\begin{array}{c}\text { Total } \\
\text { dissolved } \\
\text { (filtered) } \\
\text { nitrogen, } \\
\text { in } \mathrm{mg} / \mathrm{L} \\
\text { as } \mathrm{N}\end{array}$ & $\begin{array}{c}\text { Total } \\
\text { (unfiltered) } \\
\text { nitrogen, } \\
\text { in } \mathrm{mg} / \mathrm{L} \\
\text { as } \mathrm{N}\end{array}$ & $\begin{array}{c}\text { Sus- } \\
\text { pended- } \\
\text { sediment, } \\
\text { in } \mathrm{mg} / \mathrm{L}\end{array}$ \\
\hline & & (00061) & (90095) & (00530) & (00940) & (00608) & (00610) & (00631) & (00630) & (00666) & (00665) & (62854) & (62855) & $(80154)$ \\
\hline \multirow[t]{5}{*}{$\mathrm{D} 1^{\mathrm{a}}$} & $\begin{array}{c}\text { Number of } \\
\text { samples }\end{array}$ & 46 & 48 & 48 & 47 & 27 & 44 & 29 & 46 & 29 & 49 & 26 & 46 & 43 \\
\hline & Minimum & 0.0 & 52 & $<5$ & $<3$ & $<0.03$ & $<0.03$ & $<0.03$ & $<0.03$ & 0.29 & 0.34 & 0.76 & 0.9 & 6 \\
\hline & Maximum & 8.2 & 2,180 & 7,000 & 48 & 1.6 & 8.3 & 67 & 59 & 3.1 & 4.5 & 50 & 61 & 58,900 \\
\hline & Median & 0.2 & 217 & 115 & 4 & 0.24 & 0.29 & 1.1 & 0.91 & 0.78 & 1.3 & 3.9 & 4.0 & 213 \\
\hline & Mean & 0.8 & 348 & 903 & 7 & 0.39 & 0.86 & 6.4 & 2.9 & 0.87 & 1.4 & 6.0 & 6.3 & 3,346 \\
\hline \multirow[t]{5}{*}{$\mathrm{D} 2^{\mathrm{b}}$} & $\begin{array}{c}\text { Number of } \\
\text { samples }\end{array}$ & 15 & 17 & 14 & 17 & 13 & 16 & 13 & 16 & 13 & 16 & 13 & 16 & 17 \\
\hline & Minimum & 0.0 & 135 & 6 & $<3$ & 0.54 & 0.51 & 0.58 & 0.42 & 0.06 & 0.10 & 3.9 & 4.0 & 15 \\
\hline & Maximum & 13.0 & 1,840 & 20,000 & 71 & 2.7 & 7.6 & 12 & 13 & 1.7 & 5.8 & 21 & 29 & 514,000 \\
\hline & Median & 0.1 & 525 & 1,295 & 11 & 1.2 & 1.8 & 2.9 & 2.7 & 1.2 & 1.9 & 6.6 & 9.1 & 1,510 \\
\hline & Mean & 1.2 & 607 & 3,815 & 17 & 1.3 & 2.3 & 4.0 & 3.5 & 1.1 & 2.3 & 8.4 & 11 & 33,642 \\
\hline \multirow[t]{5}{*}{ D3 } & $\begin{array}{c}\text { Number of } \\
\text { samples }\end{array}$ & 92 & 101 & 97 & 99 & 57 & 94 & 59 & 96 & 59 & 101 & 54 & 96 & 94 \\
\hline & Minimum & 0.0 & 196 & $<5$ & 5 & $<0.03$ & $<0.03$ & $<0.03$ & $<0.03$ & $<0.01$ & $<0.01$ & 0.33 & 0.32 & 1 \\
\hline & Maximum & 48.0 & 3,300 & 6,300 & 169 & 2.6 & 2.7 & 13 & 17 & 3.2 & 5.1 & 12.7 & 16 & 15,700 \\
\hline & Median & 0.1 & 1,720 & 42 & 56 & 0.08 & 0.10 & 0.85 & 0.78 & 0.55 & 0.63 & 3.1 & 2.5 & 94 \\
\hline & Mean & 1.4 & 1,624 & 364 & 59 & 0.19 & 0.21 & 2.37 & 2.9 & 0.60 & 0.76 & 3.8 & 4.2 & 631 \\
\hline
\end{tabular}

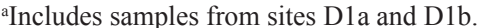

${ }^{b}$ Data only collected from March 2009 to April 2011. 


\section{Dazey Farm}

At Dazey farm from October 2008 through September 2011, about 27 samples were collected from site D1a; the site was moved about 300 feet upslope to site D1b (fig. 4), and an additional 21 samples were collected from May 2012 through September 2015 (fig. 17). The data from D1a and D1b were combined and used to estimate loads and yields and is referred to as site D1 in this section. From March 2009 through April 2011, about 17 samples were collected from site D2 before the site was destroyed (table 15). Because of issues with heavy sedimentation at site D2, associated measured flow values were not recorded for the site when samples were collected, so no further analysis was done with the sample data for this report. From April 2009 through September 2015, about 101 samples were collected from site D3 (fig. 17). Not all samples were analyzed for the same constituents, so the number of values for individual constituents varied throughout the period (table 15).

\section{Concentrations}

Chloride concentrations measured at Dazey farm were highest at site D3 and lowest at site D1 (includes samples from sites D1a and D1b) (fig. 9). Potential sources of chloride at Dazey farm could include animal manure that may have feed additives including salts from the winter feeding area (fig. 4), soils that are eroded in the area (Mullaney and others, 2009; Hem, 1985), and, specifically for site D3, groundwater input (particularly in 2010 and 2011). Although groundwater quality was not measured at Dazey farm, site D3 maintained flow throughout a large part of the year in 2010 and 2011, whereas flow at site D1 was only measured during runoff events (fig. 7). Site D1 had a median chloride concentration of $4 \mathrm{mg} / \mathrm{L}$, and site D3 had a median concentration of $56 \mathrm{mg} / \mathrm{L}$ (table 15).

Nutrient concentrations generally were greater at site D1 compared to site D3 at Dazey farm (fig. 9). Potential sources of nutrients related to agricultural activities could include animal manure in the feeding and calving areas, and fertilizer and manure applications to the surrounding cropland. Higher concentrations at site D1, which is upstream and closer to potential sources of nutrients compared to lower concentrations at site D3, which is farther downstream and receives more runoff, indicates that dilution may be the reason concentrations decrease downstream. Median total ammonia concentrations at sites D1 and D3 were 0.29 and $0.10 \mathrm{mg} / \mathrm{L}$ as nitrogen, respectively (fig. 9; table 15). Median total nitrate plus nitrite for sites D1 and D3 were 0.91 and $0.78 \mathrm{mg} / \mathrm{L}$ as nitrogen, respectively. Median total phosphorus concentrations at sites D1 and D3 were 1.3 and $0.63 \mathrm{mg} / \mathrm{L}$ as phosphorus, respectively (fig. 9; table 15).

Suspended-sediment concentrations at the Dazey farm were the highest concentrations among the sites at all three farms and decreased from upstream at site D1 downstream to site D3 (fig. 9). Median suspended-sediment concentrations for sites D1 and D3 were 213 and $94 \mathrm{mg} / \mathrm{L}$, respectively (table 15). Although median concentrations of suspended sediment were lower than the Underwood farm site U1, maximum concentrations at Dazey farm sites were much higher (tables 7 and 15). Site D1 had a maximum concentration of $58,900 \mathrm{mg} / \mathrm{L}$, and site D3 had a maximum concentration of $15,700 \mathrm{mg} / \mathrm{L}$ (table 15). In the short time site D2 was active (2009-11), a maximum concentration of 514,000 mg/L was measured (table 15). The channel at Dazey farm has a much greater slope compared to the other farms, creating more energy for erosion and sediment transport during runoff. Site D2 was destroyed in 2011 because of high sedimentation from runoff.

\section{Loads and Yields}

Annual loads (March through October) were estimated at Dazey farm from 2010-15 for site D3 and from 2012-15 for site D1 (fig. 18; table 16). Samples were collected in 2009 at both sites, but loads were not computed for 2009 at both sites and in 2010-11 at site D1 because of incomplete daily flow data. The greatest annual loads at site D3 for chloride, nitrate plus nitrite, and suspended sediment were in 2010 and 2011, and zero loads were estimated for 2012 because no flow was measured at the site (fig. 18; table 16). At site D3, annual chloride loads ranged from 0 to $6,840 \mathrm{lb} / \mathrm{yr}$, nitrate plus nitrite loads ranged from 0 to $734 \mathrm{lb} / \mathrm{yr}$ as nitrogen, and suspended-sediment loads ranged from 0 to 348,000 lb/yr (fig. 18; table 16). Total ammonia and total phosphorus loads at site D3 had the greatest loads in 2015. Annual total ammonia loads ranged from 0 to $161 \mathrm{lb} / \mathrm{yr}$ as nitrogen, and total phosphorus loads ranged from 0 to $212 \mathrm{lb} / \mathrm{yr}$ as phosphorus (fig. 18; table 16). The greatest annual loads for all constituents at site D1 were in 2014, although loads were estimated for a shorter period (2012-15) than for site D3 (2010-15). At site D1, annual chloride loads ranged from 0 to $137 \mathrm{lb} / \mathrm{yr}$, nitrate plus nitrite loads ranged from 0 to $53 \mathrm{lb} / \mathrm{yr}$ as nitrogen, and suspended-sediment loads ranged from 0 to 3,390 lb/yr (fig. 18; table 16). Annual total ammonia loads ranged from 0 to $4 \mathrm{lb} / \mathrm{yr}$ as nitrogen, and total phosphorus loads ranged from 0 to $23 \mathrm{lb} / \mathrm{yr}$ as phosphorus (fig. 18; table 16).

Mean monthly loads were greatest for most of the constituents in March and April at sites D1 and D3, on average, except for suspended sediment that had the greatest monthly loads in May (fig. 19; appendix table 1-5). Fertilizer application and cattle management data were not available for the Dazey farm, but it does not seem as though management practices affected the timing of when loads were delivered at the sites. It seems that most of the loads are delivered based on when most of the precipitation and associated runoff occurs during the year.

Annual yields were computed for sites D1 and D3 for comparison of the sites in terms of how much mass of the constituents are transported past each site per acre contributing runoff to each site (fig. 20; table 16). At site D3, the greatest annual chloride and nitrate plus nitrite yields were in 2011, 

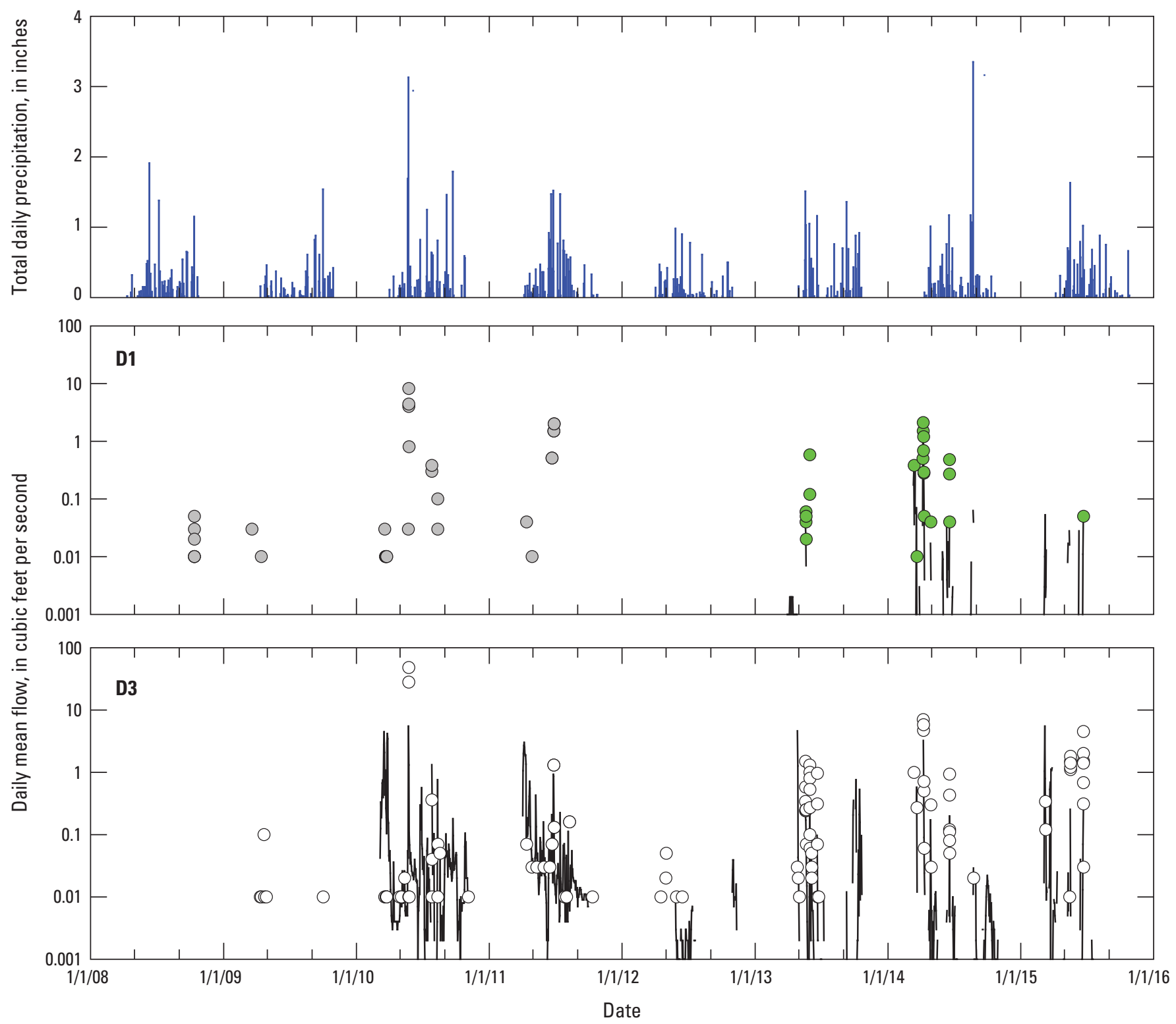

EXPLANATION

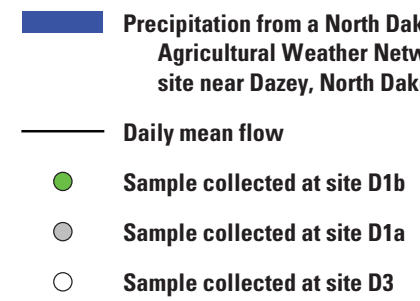

Figure 17. Daily mean flow, daily precipitation, and samples collected at monitoring sites at Dazey farm, North Dakota, 2008-15. 



Figure 18. Annual loads estimated for monitoring sites at Dazey farm, North Dakota, 2010-15. 
Table 16. Annual loads and yields for Dazey farm, North Dakota, 2010-15.

[N, nitrogen; P, phosphorus, $<$, less than]

\begin{tabular}{|c|c|c|c|c|c|c|c|c|c|c|c|}
\hline \multirow[b]{2}{*}{ Year } & \multirow[b]{2}{*}{$\begin{array}{c}\text { Flow, } \\
\text { in acre-feet } \\
\text { per year }\end{array}$} & \multicolumn{5}{|c|}{ Load, in pounds per year } & \multicolumn{5}{|c|}{ Yield, in pounds per year per acre } \\
\hline & & Chloride & $\begin{array}{c}\text { Total } \\
\text { (unfiltered) } \\
\text { ammonia, as N }\end{array}$ & $\begin{array}{c}\text { Total } \\
\text { (unfiltered) } \\
\text { nitrate plus } \\
\text { nitrite, as N }\end{array}$ & $\begin{array}{c}\text { Total } \\
\text { (unfiltered) } \\
\text { phosphorus, } \\
\text { as P }\end{array}$ & $\begin{array}{c}\text { Suspended } \\
\text { sediment }\end{array}$ & Chloride & $\begin{array}{c}\text { Total } \\
\text { (unfiltered) } \\
\text { ammonia, as N }\end{array}$ & $\begin{array}{c}\text { Total } \\
\text { (unfiltered) } \\
\text { nitrate plus } \\
\text { nitrite, as N }\end{array}$ & $\begin{array}{c}\text { Total } \\
\text { (unfiltered) } \\
\text { phosphorus, } \\
\text { as P }\end{array}$ & $\begin{array}{l}\text { Suspended } \\
\text { sediment }\end{array}$ \\
\hline \multicolumn{12}{|c|}{ Site D1 } \\
\hline 2012 & $<1$ & 0 & 0 & 0 & 0 & 0 & 0 & 0 & 0 & 0 & 0 \\
\hline 2013 & $<1$ & 3 & $<1$ & 1 & 1 & 198 & 0.12 & $<0.01$ & 0.05 & 0.04 & 8.3 \\
\hline 2014 & 8 & 137 & 4 & 53 & 23 & 3,390 & 5.7 & 0.18 & 2.2 & 0.96 & 141 \\
\hline 2015 & 1 & 8 & $<1$ & 17 & 4 & 182 & 0.34 & $<0.01$ & 0.73 & 0.18 & 7.6 \\
\hline Mean & 3 & 37 & 2 & 18 & 7 & 943 & 1.5 & 0.05 & 0.75 & 0.30 & 39 \\
\hline \multicolumn{12}{|c|}{ Site D3 } \\
\hline 2010 & 84 & 6,420 & 40 & 262 & 180 & 348,000 & 19 & 0.12 & 0.77 & 0.53 & 1,020 \\
\hline 2011 & 56 & 6,840 & 28 & 734 & 159 & 10,700 & 20 & 0.08 & 2.2 & 0.47 & 31 \\
\hline 2012 & $<1$ & 0 & 0 & 0 & 0 & 0 & 0 & 0 & 0 & 0 & 0 \\
\hline 2013 & 20 & 2,180 & 9 & 79 & 32 & 2,050 & 6.4 & 0.03 & 0.23 & 0.09 & 6.0 \\
\hline 2014 & 12 & 447 & 5 & 66 & 49 & 7,190 & 1.3 & 0.02 & 0.19 & 0.14 & 21 \\
\hline 2015 & 26 & 3,520 & 161 & 64 & 212 & 8,940 & 10 & 0.47 & 0.19 & 0.62 & 26 \\
\hline Mean & 33 & 3,230 & 41 & 201 & 106 & 62,800 & 9.5 & 0.12 & 0.59 & 0.31 & 184 \\
\hline
\end{tabular}




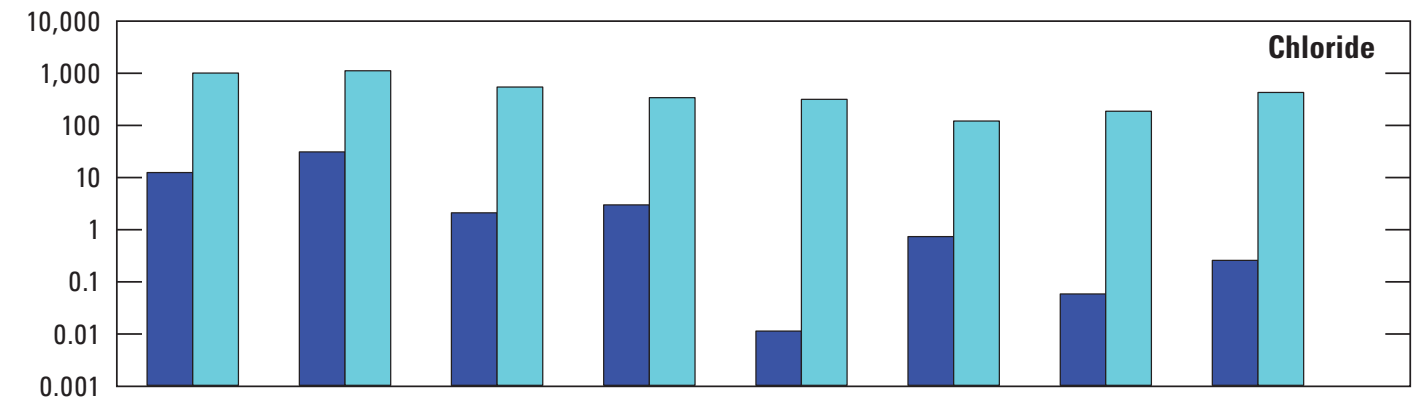

EXPLANATION

$\square$ D1
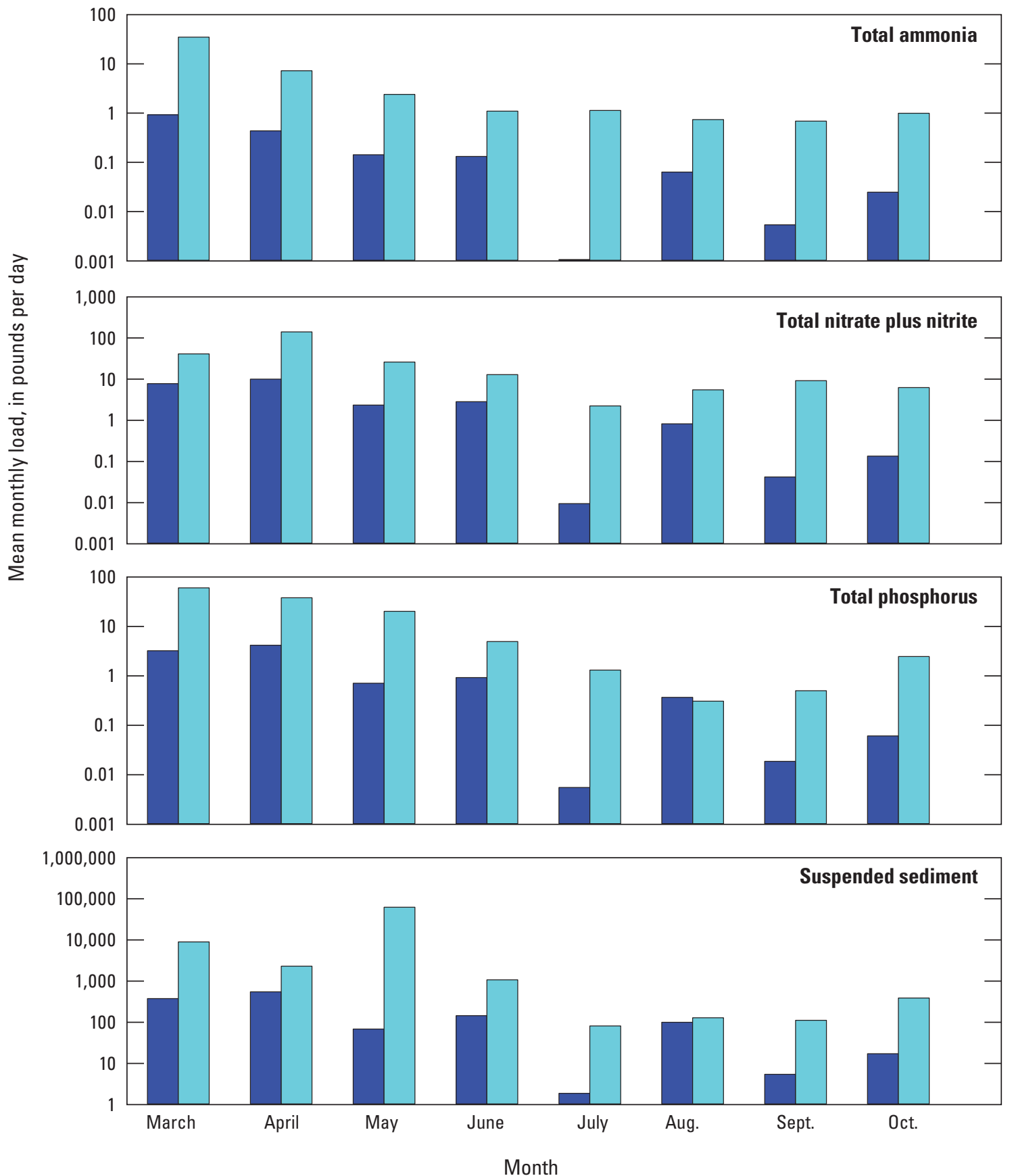

Figure 19. Monthly loads estimated for monitoring sites at Dazey farm, North Dakota, 2010-15. 

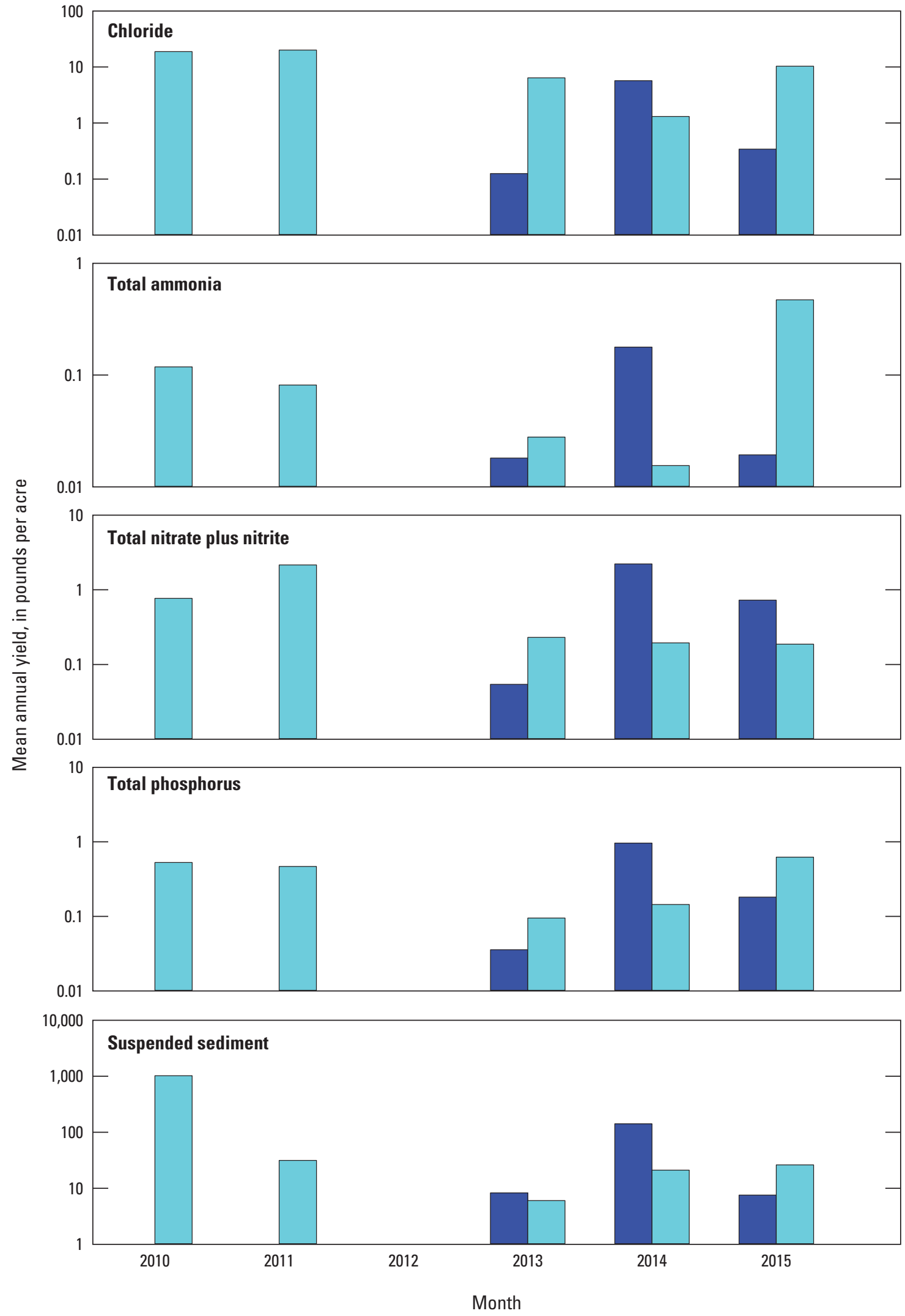

Figure 20. Annual yields estimated for monitoring sites at Dazey farm, North Dakota, 2010-15. 
the greatest total ammonia and total phosphorus yields were in 2015, and greatest suspended-sediment yields were in 2010 . At site D1, the greatest annual yields for all constituents were in 2014. Annual yields at site D1 also exceeded the annual yields estimated for site D3 for all constituents in 2014, for nitrate plus nitrite in 2015, and for suspended sediment in 2013. Annual chloride yields ranged from 0 to $5.7 \mathrm{lb} / \mathrm{yr} / \mathrm{acre}$ at site D1 and 0 to $20 \mathrm{lb} / \mathrm{yr} /$ acre at site D3 (fig. 20; table 16). Annual total ammonia yields ranged from 0 to $0.18 \mathrm{lb} / \mathrm{yr} / \mathrm{acre}$ as nitrogen at site D1 and 0 to $0.47 \mathrm{lb} / \mathrm{yr} /$ acre as nitrogen at site D3. Annual total nitrate plus nitrite yields ranged from 0 to $2.2 \mathrm{lb} / \mathrm{yr} /$ acre as nitrogen at sites D1 and D3 (fig. 20; table 16). Annual total phosphorus yields ranged from 0 to $0.96 \mathrm{lb} / \mathrm{yr} /$ acre as phosphorus at site D1, and 0 to $0.62 \mathrm{lb} / \mathrm{yr} / \mathrm{acre}$ as phosphorus at site D3. Annual suspendedsediment yields ranged from 0 to $141 \mathrm{lb} / \mathrm{yr} /$ acre at site D1, and 0 to $1,020 \mathrm{lb} / \mathrm{yr} /$ acre at site D3 (fig. 20; table 16).

To put the contribution of flow and constituent loads into a larger-scaled context, the loads and yields for Dazey farm were compared to loads and yields estimated for Baldhill Creek. Loads and yields were estimated for a site on Baldhill Creek near Dazey, N. Dak. (USGS streamgage 05057200), about 11 river miles upstream from the confluence with the drainage from Dazey farm (fig. 1 and table 10; Galloway and others, 2012). The site on Baldhill Creek has a drainage area of 442,240 acres compared to a drainage area of 341 acres for site D3 (table 10). Normalized annual loads for Baldhill Creek for total ammonia, nitrate plus nitrite, and total phosphorus were $10,000 \mathrm{lb} / \mathrm{yr}$ as nitrogen, 36,000 lb/yr as nitrogen, and 16,000 lb/yr as phosphorus, respectively (table 10; Galloway and others, 2012). In comparison, mean annual loads (2010-15) estimated for site D3 at Dazey farms for total ammonia, nitrate plus nitrite, and total phosphorus were $41 \mathrm{lb} / \mathrm{yr}$ as nitrogen, $201 \mathrm{lb} / \mathrm{yr}$ as nitrogen, and $106 \mathrm{lb} / \mathrm{yr}$ as phosphorus, respectively (table 10). Nutrient loads from the drainage at Dazey farm represent less than 1 percent of the nutrient loads estimated for the receiving stream, Baldhill Creek. Although loads were considerably less from the Dazey farm drainage compared to Baldhill Creek, nutrient yields were slightly greater but similar. For total ammonia, the normalized annual yield estimated for Baldhill Creek was $0.02 \mathrm{lb} / \mathrm{yr} /$ acre as nitrogen, whereas the mean annual yield for site D3 was $0.12 \mathrm{lb} / \mathrm{yr} /$ acre as nitrogen (table 10). The normalized annual nitrate plus nitrite yield estimated for Baldhill Creek was $0.08 \mathrm{lb} / \mathrm{yr} / \mathrm{acre}$ as nitrogen, whereas the mean annual yield for site D3 was $0.59 \mathrm{lb} / \mathrm{yr} /$ acre as nitrogen. The normalized annual total phosphorus yield estimated for Baldhill Creek was $0.04 \mathrm{lb} / \mathrm{yr} /$ acre, whereas the mean (2010-15) annual yield for site D3 was $0.31 \mathrm{lb} / \mathrm{yr} /$ acre (table 10). Suspended-sediment loads and yields were not available for Baldhill Creek for comparison (Galloway and others, 2012).

\section{Implications}

Data collected from 2008 to 2016 at the three Discovery Farms in North Dakota provides insight into several factors affecting runoff and water quality from the farms. A better understanding of these factors gives the producer data to inform agricultural management decisions that can help improve water quality in runoff from their farms.

One of the greatest factors contributing to nutrient export is one that cannot be controlled: the timing and amount of precipitation. The largest runoff volumes for the farms were in the spring when high winter precipitation was preceded by a wet fall resulting in the greatest monthly loads in the spring months. Other research has indicated similar findings in that the largest export of nutrients generally were during spring months with wet antecedent conditions (Stuntebeck and others, 2008; Davis and others, 2014). Agricultural conservation practices that target a reduction in runoff during these critical months could reduce the export of nutrients and other constituents.

Natural physiographic features on individual farms played a role in the export of certain constituents. At Underwood farm, chloride, total ammonia, and total phosphorus concentrations were the highest among the three farms, likely from a feedlot operation, but concentrations decreased as runoff traveled through a vegetated channel downstream. Sediment and phosphorus transport at Underwood farm was highest near the feedlot but decreased substantially as runoff traveled through the vegetated channel. Similarly, total ammonia, total phosphorus, and suspended-sediment concentrations at the Dazey farm decreased from upstream to downstream as runoff traveled through the natural drainage. Although sediment decreased from upstream to downstream at the Dazey farm, the greatest movement of sediment was at this farm, likely from the steeper drainage and channel compared to sites at the other farms. An at-grade stabilization structure installed on a Wisconsin Discovery Farm has reduced sediment to nearby waters (Minks and others, 2012). Natural vegetated waterways likely reduced the export of certain constituents from these farms, and additional structures, such as an at-grade stabilization structure, could be an effective means of improving water quality from farms with steeper landscapes.

Nitrogen export was affected by fertilizer application and was highest from drainage tile sites. At Underwood farm, downstream sites had higher nitrate plus nitrite concentrations, indicating sources such as fertilizer application to the surrounding cropland; however, nitrate plus nitrite concentrations were much higher at the drainage tile sites at Embden farm. Nitrate is highly soluble and probably infiltrated through the soil readily, particularly during very wet years such as 2010 and 2011, and was transported through the drainage tile. Nitrate plus nitrite concentrations and loads at the drainage tile sites also could have been affected by groundwater because the drainage tiles are in the subsurface. Drainage tiles are a large exporter of nitrogen, and factors affecting the export of nitrogen are complex and include site-specific soil properties, 
crop rotation, timing and area of nitrogen fertilizer application, amount and distribution of precipitation, crop uptake of soil derived nitrogen, and residual nitrogen remaining after harvest (Stenberg and others, 2011; Gentry and others, 1998; University of Wisconsin, 2013). Compared to receiving water bodies, nitrogen losses from the drainage tiles are small, but cumulatively, if many farms are losing nitrogen through drainage tiles, the total loss of nitrogen can result in increasing surface-water nitrogen concentrations (Blann and others, 2009). Because of the complexity of factors affecting nitrogen export from drainage tiles, agricultural practices on tile-drained agricultural land must be taken into consideration for the individual cropping system and site-specific characteristics to reduce nutrient loss (University of Wisconsin, 2013; Stenberg and others, 2011; Gentry and others, 1998).

To mitigate runoff and water-quality effects of their operations, various agricultural conservation practices were implemented by the producers before and during the Discovery Farms monitoring. At Underwood farm, because of data collected for the Discovery Farms program, the producer installed a drainage ditch to route runoff away from the feedlot, but the effects of the ditch could not be quantified because of variability in hydrologic conditions during the monitoring period. At the Dazey farm, the producer relocated the feedlot before the start of data collection for the Discovery Farms program, and effects of the relocation could not be determined because data were not collected before the relocation. Although the effects of these agricultural conservation practices could not be quantified definitively, data collected at Underwood and Dazey farms demonstrate that runoff through a vegetated channel resulted in decreased concentrations of some constituents. This indicates that, over time, these conservation practices could reduce effects to downstream water bodies. At Embden farm, the producer rotated crops, used different fertilizer application rates, and planted alfalfa in a part of the operation for consecutive years. Direct correlations could not be made definitively from the data at Embden farm, but it did seem that some of these measures had an effect on the amount of nutrients transported from the site. Conservation practices implemented by the producers likely caused a reduction in nutrient loss, but high variability in other factors such as precipitation and runoff makes it difficult to quantify the reduction. To quantify these reductions, many years of consistent data collection is required and monitoring before and subsequent to implementation of the practices is necessary. Even though it was difficult to quantify the effects of the agricultural conservation practices implemented at the farms, the data collected from the Discovery Farms program provided a better understanding of some of the variables that affect runoff and water quality, and on the basis of this information, producers can modify their agricultural practices to more effectively protect downstream water quality.

\section{Summary}

Agricultural producers in North Dakota are aware of concerns about degrading water quality, and many of the producers are interested in implementing conservation practices to reduce the export of nutrients from their farms, not only because it reduces the effect on receiving waters, but also because it is beneficial to the producer to retain nutrients. Producers often implement conservation practices without knowledge of the water quality of the runoff from their farm or if conservation practices they may implement have any effect on water quality. In response to this lack of information, the U.S. Geological Survey, in cooperation with North Dakota State University Extension Service and in coordination with an advisory group consisting of State agencies, agricultural producers, and commodity groups, implemented a monitoring study as part of a Discovery Farms program in North Dakota in 2007. Discovery Farms in North Dakota were established in late 2007 near Underwood, North Dakota, in late 2008 near Embden, North Dakota, and in early 2008 near Dazey, North Dakota. Each farm had three data-collection sites. The purpose of this report is to describe runoff and water-quality characteristics from data collected at the three Discovery Farms from 2008 to 2016. Runoff and water-quality data were used to help describe the implication of agricultural conservation practices on runoff and water-quality patterns.

Runoff characteristics of monitoring sites at the three farms were determined by measuring flow volume and precipitation. Runoff at the Underwood farm monitoring sites generally was controlled by precipitation in the area, antecedent soil moisture conditions, and, after 2012, possibly by the diversion ditch constructed by the producer. Flow volume was highest at the most downstream site U3; annual flow volumes ranged from 136 acre-feet (2012) to 15,200 acre-feet (2011). Measured runoff consistently was highest at site U1 (most upstream site) and was lowest at site U2. Most of the annual runoff was in March and April each year during spring snowmelt. The large monthly totals did not happen in months with high rainfall totals but were preceded by wet conditions in the previous fall months and higher precipitation in the preceding winter months.

Runoff characteristics at the Embden farm are complex because of the mix of surface runoff (measured at site E1) and flow through two separate drainage tile systems (sites E2 and E3). Annual flow volume at site E1 ranged from less than 4 acre-feet (2013) to 1,820 acre-feet (2011). Annual flow volumes for the drainage tiles sites E2 and E3 were much greater than measured at site E1. Site E1 generally only had runoff briefly in March and April during spring snowmelt and during only a few large rain events throughout 2009-16; however, runoff was somewhat continuous at sites E2 and E3 throughout the year during years of increased precipitation such as in 2010 and 2011. 
At Dazey farm, annual flow volumes at the most downstream site D3 for 2010-15 ranged from 88 acre-feet (2012) to 12,100 acre-feet (2010). Annual flow volumes for upstream site D1 (combination of data from site D1a [original site] and site D1b [relocated site]) for 2013-15 ranged from 49 acrefeet (2013) to 1,190 acre-feet (2014). The largest monthly runoff volumes at sites D1 and D3 were in March and April during spring snowmelt runoff and rain events. Site D1 had only one period of measurable monthly runoff that was in March and April 2014.

Data collected from 2008 to 2016 at the three Discovery Farms in North Dakota provides insight into several factors affecting runoff and water quality from the farms. A better understanding of these factors gives the producer data to inform agricultural management decisions that can help improve water quality in runoff from their farms.

Chloride concentrations measured at Underwood generally were highest at site $\mathrm{U} 1$ and lowest at site U2. In general, chloride concentrations also were higher at Underwood farm compared to Dazey and Embden farms. Chloride concentrations measured at Embden farm were similar for the two drainage tile sites (E2 and E3) and were considerably higher than at the surface-water site (E1). Chloride concentrations measured at Dazey farm were highest at downstream site D3 and lowest at upstream site D1.

Total ammonia and total phosphorus had the highest concentrations at Underwood farm site U1 and decreased sequentially at sites U2 and U3 downstream. Total ammonia and phosphorus concentrations at the sites for Underwood farm also generally were higher than measured at Dazey and Embden farms. Nitrate plus nitrite generally had the lowest concentrations at site U1 and the highest concentrations at site U2, although median concentrations did not vary substantially among sites. Median total nitrate plus nitrite concentrations for sites $\mathrm{U} 1, \mathrm{U} 2$, and $\mathrm{U} 3$ were $1.3,2.5$, and 1.4 milligrams per liter as nitrogen, respectively. Nutrient concentrations were similar for the Embden farm drainage tile sites E2 and E3; concentrations of total ammonia and total phosphorus were lower and concentrations of total nitrate plus nitrite were higher compared to the surface-water site E1. Nitrate plus nitrite concentration at sites E2 and E3 also were the highest among all of the sites at all three farms. Median total nitrate plus nitrite for sites E1, E2, and E3 were 0.22, 13, and 10 milligrams per liter as nitrogen, respectively. Nitrate plus nitrite has been found to be higher in drain tiles because runoff can readily transport nitrates that were applied as fertilizer into the subsurface before it can be processed by vegetation on the surface and nitrates can be leeched from the soil as the water travels into the drain tiles. Nutrient concentrations generally were greater at site D1 compared to site D3 at Dazey farm. Higher concentrations at site D1, which is upstream and closer to potential sources of nutrients compared to lower concentrations at site $\mathrm{D} 3$, which is farther downstream and receives more runoff, indicates that dilution may be the reason concentrations decrease downstream.
Suspended-sediment concentrations decreased from upstream at site U1 downstream to site U3 at Underwood farm. Higher concentrations at site U1 are likely from soil that is exposed and loosened in the feedlot and is readily transported during runoff. At Embden farm, suspended sediment was measured only at site E1, and concentrations were the lowest at E1 among all the sites at all three farms. Suspendedsediment concentrations at the Dazey farm were the highest concentrations among the sites at all three farms and decreased from upstream at site D1 downstream to site D3.

Annual loads for chloride at all three Underwood sites were the greatest in 2011 and the least in 2012, which coincided with years of the greatest and least annual flow volume, respectively. Total ammonia had a similar pattern at sites U1 and U3; annual loads were the greatest in 2011 and the least in 2012. Nitrate plus nitrite loads displayed a different pattern than chloride and total ammonia, indicating possible different sources. The greatest nitrate plus nitrite loads were in 2010 at site U1 and in 2014 at sites U2 and U3. Annual nitrate plus nitrite loads also were consistently greater at sites $\mathrm{U} 2$ and $\mathrm{U} 3$ when compared to site U1 except for 2012. Chloride, total ammonia, total phosphorus, and suspended sediment were transported past site U1 mostly in March and the least from July through October. Monthly nitrate plus nitrite loads had a different pattern than the other constituents, indicating other possible sources such as fertilizer application in the surrounding cropland. Although the greatest loads at site U1 were in March, a large amount of nitrate plus nitrite was transported past sites U2 and U3 in March through June, and the greatest monthly loads were in June for site U2 and March for site U3. Depending on the constituent, annual yields were between 2 and 1,000 times greater at site U1, compared to sites U2 and $\mathrm{U} 3$, mainly because of a combination of higher measured concentrations and smaller contributing drainage area for site U1.

Annual loads for Embden farm were considerably greater at sites E2 and E3 compared to site E1. Annual loads for chloride at all three sites were the greatest in 2010 and 2011 and the least in 2012 or 2013, which coincided with years of the greatest and least annual flow volume, respectively. Total ammonia loads were greatest at site E3 most years except for 2011 and 2013, when site E2 had the greatest load among the three sites, and 2012, when site E1 had the greatest load. Annual total ammonia loads ranged from less than 1 to 3 pounds per year as nitrogen at site E1, from less than 1 to 79 pounds per year as nitrogen at site $\mathrm{E} 2$, and from less than 1 to 89 pounds per year as nitrogen at site E3. Nitrate plus nitrite loads were greatest at sites E2 and E3, and the greatest annual loads were in 2010 and 2011. Some of the patterns in annual load could be explained by crop management and fertilizer application in the fields that contribute runoff to the three sites. Annual yields for all constituents were substantially greater at sites E2 and E3 compared to site E1, mainly because of a combination of higher flow volumes and small contributing drainage areas at sites E2 and E3 compared to site E1. 
The greatest annual loads at Dazey farm site D3 for chloride, nitrate plus nitrite, and suspended sediment were in 2010 and 2011, and zero loads were estimated for 2012 because no flow was measured at the site. Mean monthly loads were greatest for most of the constituents in March and April at sites D1 and D3, on average, except for suspended sediment that had the greatest monthly loads in May. At site D3, the greatest annual chloride and nitrate plus nitrite yields were in 2011, the greatest total ammonia and total phosphorus yields were in 2015, and greatest suspended-sediment yields were in 2010. At site D1, the greatest annual yields for all constituents were in 2014.

To mitigate runoff and water-quality effects of their operations, various agricultural conservation practices were implemented by the producers, before and during the Discovery Farms monitoring. Conservation practices implemented by the producers likely caused a reduction in nutrient loss, but high variability in other factors such as precipitation and runoff makes it difficult to quantify the reduction. Even though it was difficult to quantify the effects of the agricultural conservation practices implemented at the farms, the data collected from the Discovery Farms program provided a better understanding of some of the variables that affect runoff and water quality, and on the basis of this information, producers can modify their agricultural practices to more effectively protect downstream water quality.

\section{References Cited}

Blann, K.L., Anderson, J.L., Sands, G.R., and Vondracek, B., 2009, Effects of agricultural drainage on aquatic ecosystems - a review: Critical Reviews in Environmental Science and Technology, v. 39, no. 11, p. 909-1001. [Also available at https://doi.org/10.1080/10643380801977966.]

Clesceri, L.S., Greenberg, A.E., and Eaton, A.D., eds., 1999, Standard methods for the examination of water and wastewater (20th ed.): American Public Health Association, $1,325 \mathrm{p}$.

Davis, C.A., Ward, A.S., Burgin, A.J., Loecke, T.D., Riveros-Iregui, D.A., Schnoebelen, D.J., Just, C.L., Thomas, S.A., Weber, L.J., and St. Clair, M.A., 2014, Antecedent moisture controls on stream nitrate flux in an agricultural watershed: Journal of Environmental Quality, v. 43, no. 4, p. 1494-1503. [Also available at https://doi.org/10.2134/ jeq2013.11.0438.]

Galloway, J.M., Vecchia, A.V., Vining, K.C., Densmore, B.K., and Lundgren, R.F., 2012, Evaluation of water-quality characteristics and sampling design for streams in North Dakota, 1970-2008: U.S. Geological Survey Scientific Investigations Report 2012-5216, 304 p. [Also available at https://pubs.usgs.gov/sir/2012/5216/.]
García, A.M., Alexander, R.B., Arnold, J.G., Norfleet, L., White, M.J., Robertson, D.M., and Schwarz, G., 2016, Regional effects of agricultural conservation practices on nutrient transport in the Upper Mississippi River Basin: Environmental Science and Technology, v. 50, p. 6991-7000. [Also available at https://dx.doi.org/10.1021/ acs.est.5b03543.]

Gentry, L.E., David, M.B., Smith, K.M., and Kovacic, D.A., 1998, Nitrogen cycling and tile drainage nitrate loss in a corn/soybean watershed: Agriculture, Ecosystems and Environment, v. 68, nos. 1-2, p. 85-97. [Also available at https://doi.org/10.1016/S0167-8809(97)00139-4.]

Hem, J.D., 1985, Study and interpretation of the chemical characteristics of natural water: U.S. Geological Survey Water-Supply Paper 2254, $263 \mathrm{p}$.

High Plains Regional Climate Center, 2017, High Plains Regional Climate Center: accessed May 8, 2017, at https://hprcc.unl.edu/.

Minks, K.R., Lowery, B., Madison, F.W, Ruark, M.D., Frame, D., Stuntebeck, T. and Komiskey, M., 2012, An at-grade stabilization structure impact on runoff and suspended sediment: Journal of Soil and Water Conservation, v. 67, no. 4, p. 237-248 [Also available at https://doi.org/10.2489/ jswc.67.4.237.]

Mullaney, J.R., Lorenz, D.L., and Arntson, A.D., 2009, Chloride in groundwater and surface water in areas underlain by the glacial aquifer system, northern United States: U.S. Geological Survey Scientific Investigations Report 2009-5086, 41 p. [Also available at https://pubs.usgs.gov/ $\operatorname{sir} / 2009 / 5086 /$.

Minnesota Department of Agriculture, 2017, Discovery Farms Minnesota: accessed July 14, 2017, at http://www.mda.state.mn.us/protecting/cleanwaterfund/ onfarmprojects/discoveryfarmsmn.aspx.

North Dakota, 2017, North Dakota legendary: accessed July 12, 2017, at http://www.ndstudies.org/resources/ legendary/quick-facts.html.

North Dakota Agricultural Weather Network, 2017, Daily Weather Data: accessed March 31, 2017, at https://ndawn.ndsu.nodak.edu/weather-data-daily.html.

North Dakota State University, 2009, Enabling grass-roots, intensive, runoff water monitoring projects: the North Dakota Discovery Farms: accessed December 5, 2014, at http://www.ag.ndsu.edu/df/documents/ 7-09DiscoveryFarmsNCER.pdf. 
Nustad, R.A., Rowland, K.M., and Wiederholt, R.G., 2015, Water-quality characteristics in runoff for three discovery farms in North Dakota, 2008-12: U.S. Geological Survey Scientific Investigations Report 2014-5212, 31 p. [Also available at https://doi.org/10.3133/sir20145212.]

Sauer, V.B., and Turnipseed, D.P., 2010, Stage measurement at gaging stations: U.S. Geological Survey Techniques and Methods, book 3, chap. A7, 45 p. [Also available at https://pubs.usgs.gov/tm/tm3-a7/].

Stenberg, M., Ulen, B., Soderstrom, M., Roland, B., Delin, K., and Helander, C., 2011, Tile drain losses of nitrogen and phosphorus from fields under integrated and organic crop rotations-A four-year study on a clay soil in southwest Sweden: Science of the Total Environment, v. 434, p. 79-89. [Also available at https://dx.doi.org/10.1016/j.scitotenv.2011.12.039.]

Stuntebeck, T.D., Komiskey, M.J., Owens, D.W., and Hall, D.W., 2008, Methods of data collection, sample processing, and data analysis for edge-of-field, streamgaging, subsurface-tile, and meteorological stations at Discovery Farms and Pioneer Farm in Wisconsin, 2001-7: U.S. Geological Survey Open-File Report 2008-1015, 51 p. [Also available at https://pubs.usgs.gov/of/2008/1015/.]

University of Arkansas, 2017, Discovery Farms: accessed July 14, 2017, at http://discoveryfarms.uark.edu/.

University of Wisconsin, 2013, Tile drainage in Wisconsin: accessed July 14, 2017, at http://www.uwdiscoveryfarms.org/UWDiscoveryFarms/ media/sitecontent/PublicationFiles/agtiledrainage/4-TileDrainage-Insert.pdf?ext=.pdf.

University of Wisconsin, 2017, Discovery Farms Wisconsin: accessed July 14, 2017, at http://www.uwdiscoveryfarms.org/.

U.S. Department of Agriculture, 2014, Assessment of the effects of conservation practices on cultivated cropland in the Souris-Red-Rainy-Basin: accessed July 14, 2017, at https://www.nrcs.usda.gov/Internet/FSE_DOCUMENTS/ stelprdb1260130.pdf.

U.S. Environmental Protection Agency, 2015, Ag101: accessed July 7, 2017, at https:/www.epa.gov/sites/ production/files/2015-07/documents/ag_101_agriculture_ us_epa_0.pdf.

U.S. Environmental Protection Agency, 2017a, Polluted runoff-nonpoint source pollution: accessed July 7, 2017, at https://www.epa.gov/nps/nonpoint-source-agriculture.

U.S. Environmental Protection Agency, 2017b, North Dakota water quality assessment report, accessed July 7, 2017, at https://ofmpub.epa.gov/waters10/attains_state.control?p_ state=ND\#STREAM/CREEK/RIVER.
U.S. Environmental Protection Agency, 2017c, Approved general-purpose methods: accessed July 12, 2017, at http://water.epa.gov/scitech/methods/cwa/methods_index. $\mathrm{cfm}$.

U.S. Geological Survey, 2017, National Water Information System (NWIS): U.S. Geological Survey database, accessed April 1, 2017, at http://nwis.waterdata.usgs.gov/nd/nwis. [Also available at https://doi.org/10.5066/F7P55KJN.]

White, P.J., and Broadley, M.R., 2001, Chloride in soils and its uptake and movement within the plant: a review: Annals of Botany, 88: 967-988, 2001 [Also available at https://doi.org/10.1006/anbo.2001.1540] 



\section{Appendix 1. Additional Runoff and Water- Quality Data for Monitoring Sites at Three Discovery Farms in North Dakota, 2008-16}


Table 1-1. Summary of additional water-quality constituent concentrations for selected samples collected at Discovery Farm monitoring sites, North Dakota, 2008-16.

[Number in parentheses is the U.S. Geological Survey National Water Information System parameter code; $\mathrm{mg} / \mathrm{L}$, milligram per liter; $\mathrm{CaCO}_{3}$, calcium carbonate; $\mathrm{SiO}_{2}$, silica; $\mu \mathrm{g} / \mathrm{L}$, microgram per liter; $<$, less than]

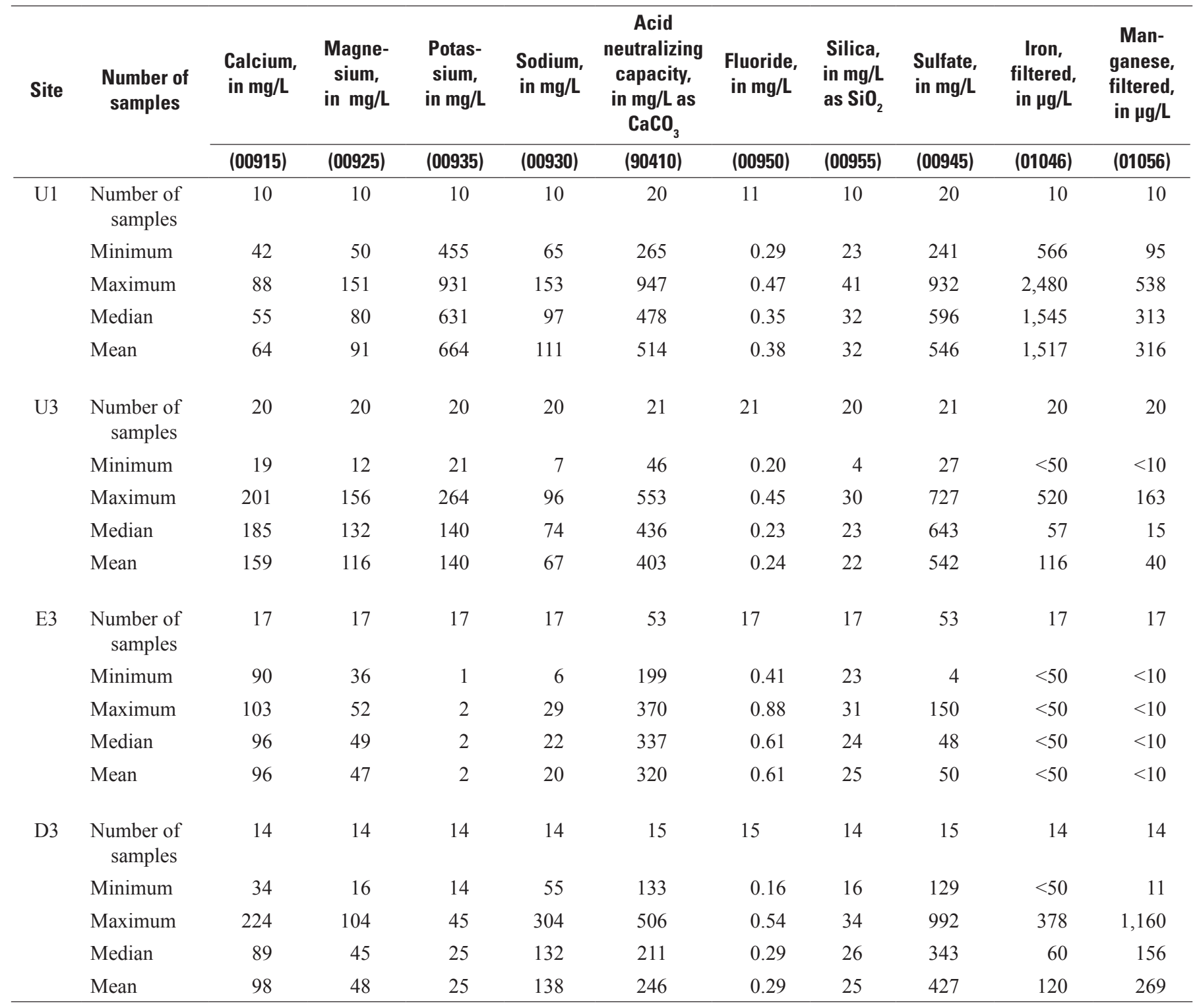


Table 1-2. Quality assurance data collected at Discovery Farm monitoring sites, North Dakota, 2008-16.

$\left[\mu \mathrm{S} / \mathrm{cm}\right.$ at $25^{\circ} \mathrm{C}$, microsiemen per centimeter at 25 degrees Celsius; $\mathrm{mg} / \mathrm{L}$, milligram per liter; $\mathrm{N}$, nitrogen; P, phosphorus, $<$, less than; --, not available]

\begin{tabular}{|c|c|c|c|c|c|c|c|c|c|c|c|c|c|}
\hline Site & Date & $\begin{array}{c}\text { Specific } \\
\text { conduct- } \\
\text { ance, } \\
\text { laboratory, } \\
\text { in } \mu \mathrm{S} / \mathrm{cm} \text { at } \\
25^{\circ} \mathrm{C} \\
\end{array}$ & $\begin{array}{l}\text { Suspended } \\
\text { solids, } \\
\text { in } \mathrm{mg} / \mathrm{L}\end{array}$ & $\begin{array}{c}\text { Chloride, } \\
\text { in } \mathrm{mg} / \mathrm{L}\end{array}$ & $\begin{array}{c}\text { Dissolved } \\
\text { (filtered) } \\
\text { ammonia, } \\
\text { in } \mathrm{mg} / \mathrm{L} \\
\text { as } \mathrm{N}\end{array}$ & $\begin{array}{c}\text { Total } \\
\text { (unfiltered) } \\
\text { ammonia, } \\
\text { in } \mathrm{mg} / \mathrm{L} \\
\text { as N }\end{array}$ & $\begin{array}{c}\text { Dissolved } \\
\text { (filtered) } \\
\text { nitrate plus } \\
\text { nitrite, } \\
\text { in } \mathrm{mg} / \mathrm{L} \\
\text { as } \mathrm{N} \\
\end{array}$ & $\begin{array}{c}\text { Total nitrate } \\
\text { plus nitrite } \\
\text { (unfiltered), } \\
\text { in } \mathrm{mg} / \mathrm{L} \\
\text { as } \mathrm{N}\end{array}$ & $\begin{array}{c}\text { Dissolved } \\
\text { (filtered) } \\
\text { phosphorus, } \\
\text { in } \mathrm{mg} / \mathrm{L} \\
\text { as P }\end{array}$ & 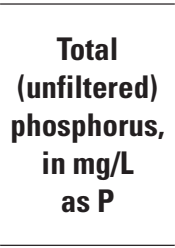 & $\begin{array}{c}\text { Total } \\
\text { dissolved } \\
\text { (filtered) } \\
\text { nitrogen, } \\
\text { in } \mathrm{mg} / \mathrm{L} \\
\text { as } \mathrm{N}\end{array}$ & $\begin{array}{c}\text { Total } \\
\text { (unfiltered) } \\
\text { nitrogen, } \\
\text { in } \mathrm{mg} / \mathrm{L} \\
\text { as } \mathrm{N}\end{array}$ & $\begin{array}{l}\text { Suspended- } \\
\text { sediment, } \\
\text { in } \mathrm{mg} / \mathrm{L}\end{array}$ \\
\hline \multicolumn{14}{|c|}{ Field blanks } \\
\hline U1 & $5 / 18 / 2011$ & 26 & 6 & 3 & $<0.03$ & $<0.03$ & 0.07 & 0.07 & 0.01 & 0.024 & 0.1 & 0.2 & -- \\
\hline $\mathrm{U} 2$ & $5 / 18 / 2011$ & 24 & $<5$ & 3 & 0.04 & 0.04 & 0.07 & 0.07 & 0.04 & 0.041 & 0.3 & 0.4 & -- \\
\hline U3 & $5 / 18 / 2011$ & 22 & $<5$ & 3 & $<0.03$ & $<0.03$ & 0.06 & 0.06 & 0.01 & 0.007 & 0.1 & 0.1 & -- \\
\hline E1 & 4/7/2016 & 4 & 11 & $<1$ & 0.09 & $<0.03$ & 0.03 & 0.03 & 0.02 & 0.020 & 0.1 & 0.1 & -- \\
\hline \multicolumn{14}{|c|}{ Replicates } \\
\hline \multirow[t]{2}{*}{ U1 } & $6 / 3 / 2008$ & 4,500 & 42 & 519 & -- & 4.3 & -- & 4.9 & -- & 25 & -- & 80 & 653 \\
\hline & $6 / 3 / 2008$ & 4,500 & 43 & 523 & -- & 4.2 & -- & 4.9 & -- & 25 & -- & 83 & 480 \\
\hline \multirow[t]{2}{*}{ U1 } & $3 / 17 / 2009$ & 1,680 & 54 & 66 & -- & 42 & -- & 0.78 & -- & 14 & -- & 147 & 293 \\
\hline & $3 / 17 / 2009$ & 1,700 & 52 & 62 & -- & 43.8 & -- & 0.77 & -- & 17 & -- & 149 & 285 \\
\hline \multirow[t]{2}{*}{ D1 } & 3/19/2009 & 361 & 10 & 7 & -- & 8.5 & -- & $<0.03$ & -- & 3.1 & -- & 22 & 26 \\
\hline & 3/19/2009 & 356 & 6 & 7 & -- & 8.3 & -- & 0.65 & -- & 2.7 & -- & 21 & 13 \\
\hline \multirow[t]{2}{*}{ E1 } & $3 / 24 / 2009$ & 91 & 7 & 2 & -- & 0.39 & -- & 0.45 & -- & 0.28 & -- & 1.7 & -- \\
\hline & $3 / 24 / 2009$ & 91 & 6 & $<6$ & -- & 0.38 & -- & 0.41 & -- & 0.28 & -- & 1.6 & -- \\
\hline \multirow[t]{2}{*}{ E2 } & $3 / 24 / 2009$ & 168 & 7 & 4 & -- & 0.30 & -- & 1.7 & -- & 0.23 & -- & 2.8 & -- \\
\hline & $3 / 24 / 2009$ & 168 & $<5$ & 4 & -- & 0.31 & -- & 1.7 & -- & 0.23 & -- & 2.9 & -- \\
\hline \multirow[t]{2}{*}{ E2 } & $4 / 21 / 2009$ & 837 & $<5$ & 24 & -- & $<0.03$ & -- & 17 & -- & 0.02 & -- & 17 & -- \\
\hline & $4 / 21 / 2009$ & 837 & $<5$ & 24 & -- & $<0.03$ & -- & 18 & -- & 0.02 & -- & 17 & -- \\
\hline \multirow[t]{2}{*}{ D3 } & $4 / 21 / 2009$ & 1,210 & 243 & 46 & -- & 0.12 & -- & 1.2 & -- & 0.58 & -- & 2.9 & -- \\
\hline & $4 / 21 / 2009$ & 1,210 & 230 & 48 & -- & 0.16 & -- & 1.2 & -- & 0.58 & -- & 2.9 & -- \\
\hline \multirow[t]{2}{*}{ E3 } & $4 / 21 / 2009$ & 1,070 & $<5$ & 31 & -- & $<0.03$ & -- & 12 & -- & 0.02 & -- & 12 & -- \\
\hline & $4 / 21 / 2009$ & 1,070 & $<5$ & 31 & -- & $<0.03$ & -- & 12 & -- & 0.02 & -- & 12 & -- \\
\hline \multirow[t]{2}{*}{ U1 } & $4 / 22 / 2009$ & 409 & 145 & 12 & -- & 9.4 & -- & 0.66 & -- & 4.2 & -- & 18 & -- \\
\hline & 4/22/2009 & 409 & 147 & 13 & -- & 9.5 & -- & 0.76 & -- & 4.2 & -- & 18 & -- \\
\hline \multirow[t]{2}{*}{$\mathrm{U} 2$} & $4 / 22 / 2009$ & 568 & 37 & 21 & -- & 9.0 & -- & 0.16 & -- & 5.2 & -- & 16 & -- \\
\hline & $4 / 22 / 2009$ & 567 & 35 & 21 & -- & 9.4 & -- & 0.11 & -- & 5.3 & -- & 16 & -- \\
\hline \multirow[t]{2}{*}{ U3 } & $4 / 22 / 2009$ & 648 & $<5$ & 25 & -- & 4.6 & -- & 0.12 & -- & 4.1 & -- & 13 & -- \\
\hline & $4 / 22 / 2009$ & 648 & $<5$ & 25 & -- & 4.5 & -- & 0.10 & -- & 4.0 & -- & 12 & -- \\
\hline
\end{tabular}


Table 1-2. Quality assurance data collected at Discovery Farm monitoring sites, North Dakota, 2008-16. - Continued

$\left[\mu \mathrm{S} / \mathrm{cm}\right.$ at $25^{\circ} \mathrm{C}$, microsiemen per centimeter at 25 degrees Celsius; $\mathrm{mg} / \mathrm{L}$, milligram per liter; $\mathrm{N}$, nitrogen; $\mathrm{P}$, phosphorus, $<$, less than; --, not available]

\begin{tabular}{|c|c|c|c|c|c|c|c|c|c|c|c|c|c|}
\hline Site & Date & $\begin{array}{c}\text { Specific } \\
\text { conduct- } \\
\text { ance, } \\
\text { laboratory, } \\
\text { in } \mu \mathrm{S} / \mathrm{cm} \text { at } \\
25^{\circ} \mathrm{C}\end{array}$ & $\begin{array}{c}\text { Suspended } \\
\text { solids, } \\
\text { in } \mathrm{mg} / \mathrm{L}\end{array}$ & $\begin{array}{c}\text { Chloride, } \\
\text { in } \mathrm{mg} / \mathrm{L}\end{array}$ & $\begin{array}{l}\text { Dissolved } \\
\text { (filtered) } \\
\text { ammonia, } \\
\text { in } \mathrm{mg} / \mathrm{L} \\
\text { as } \mathrm{N}\end{array}$ & $\begin{array}{c}\text { Total } \\
\text { (unfiltered) } \\
\text { ammonia, } \\
\text { in } \mathrm{mg} / \mathrm{L} \\
\text { as } \mathrm{N}\end{array}$ & $\begin{array}{l}\text { Dissolved } \\
\text { (filtered) } \\
\text { nitrate plus } \\
\text { nitrite, } \\
\text { in } \mathrm{mg} / \mathrm{L} \\
\text { as } \mathrm{N}\end{array}$ & $\begin{array}{l}\text { Total nitrate } \\
\text { plus nitrite } \\
\text { (unfiltered), } \\
\text { in } \mathrm{mg} / \mathrm{L} \\
\text { as } \mathrm{N}\end{array}$ & $\begin{array}{l}\text { Dissolved } \\
\text { (filtered) } \\
\text { phosphorus, } \\
\text { in } \mathrm{mg} / \mathrm{L} \\
\text { as } \mathrm{P}\end{array}$ & $\begin{array}{c}\text { Total } \\
\text { (unfiltered) } \\
\text { phosphorus, } \\
\text { in } \mathrm{mg} / \mathrm{L} \\
\text { as } \mathrm{P}\end{array}$ & $\begin{array}{c}\text { Total } \\
\text { dissolved } \\
\text { (filtered) } \\
\text { nitrogen, } \\
\text { in } \mathrm{mg} / \mathrm{L} \\
\text { as } \mathrm{N}\end{array}$ & $\begin{array}{c}\text { Total } \\
\text { (unfiltered) } \\
\text { nitrogen, } \\
\text { in } \mathrm{mg} / \mathrm{L} \\
\text { as } \mathrm{N}\end{array}$ & $\begin{array}{l}\text { Suspended- } \\
\text { sediment, } \\
\text { in } \mathrm{mg} / \mathrm{L}\end{array}$ \\
\hline \multicolumn{14}{|c|}{ Replicates-Continued } \\
\hline \multirow[t]{2}{*}{ E2 } & $10 / 2 / 2009$ & 847 & 23 & 21 & -- & 0.09 & -- & 14 & -- & 0.22 & -- & 15 & -- \\
\hline & $10 / 2 / 2009$ & 852 & 6 & 21 & -- & $<0.03$ & -- & 16 & -- & 0.15 & -- & 17 & -- \\
\hline \multirow[t]{2}{*}{ U1 } & $3 / 20 / 2010$ & 1,140 & 152 & 31 & -- & 30 & -- & 0.57 & -- & 14 & -- & 45 & 301 \\
\hline & $3 / 20 / 2010$ & 1,140 & 199 & 31 & -- & 31 & -- & 0.82 & -- & 15 & -- & 48 & 302 \\
\hline \multirow[t]{2}{*}{$\mathrm{U} 2$} & $3 / 20 / 2010$ & 255 & $<5$ & 5 & -- & 1.1 & -- & 3.1 & -- & 1.9 & -- & 7.1 & 9 \\
\hline & $3 / 20 / 2010$ & 254 & 6 & 5 & -- & 1.1 & -- & 3.0 & -- & 1.8 & -- & 8.6 & 10 \\
\hline \multirow[t]{2}{*}{ U3 } & $3 / 20 / 2010$ & 316 & 7 & 7 & 2.9 & 3.0 & 2.4 & 2.4 & 1.9 & 2.2 & 9.1 & 9.9 & -- \\
\hline & $3 / 20 / 2010$ & 316 & 7 & 7 & 3.0 & 3.0 & 2.4 & 2.4 & 2.0 & 2.2 & 9.4 & 10 & -- \\
\hline \multirow[t]{2}{*}{ E1 } & $3 / 22 / 2010$ & 216 & $<5$ & 4 & $<0.03$ & $<0.03$ & 0.42 & 0.43 & 0.25 & 0.26 & 1.6 & 1.3 & 2 \\
\hline & $3 / 22 / 2010$ & 215 & $<5$ & 4 & $<0.03$ & $<0.03$ & 0.43 & 0.43 & 0.26 & 0.26 & 1.5 & 1.4 & 1 \\
\hline \multirow[t]{2}{*}{ E2 } & $3 / 22 / 2010$ & 707 & $<5$ & 17 & $<0.03$ & $<0.03$ & 11 & 11 & 0.05 & 0.07 & 12 & 12 & -- \\
\hline & $3 / 22 / 2010$ & 712 & $<5$ & 18 & $<0.03$ & $<0.03$ & 11 & 12 & 0.06 & 0.06 & 11 & 12 & -- \\
\hline \multirow[t]{2}{*}{ E3 } & $3 / 22 / 2010$ & 922 & $<5$ & 21 & $<0.03$ & $<0.03$ & 9.4 & 9.7 & 0.03 & 0.03 & 10 & 10 & -- \\
\hline & $3 / 22 / 2010$ & 922 & $<5$ & 21 & $<0.03$ & $<0.03$ & 8.9 & 9.4 & 0.03 & 0.03 & 9.7 & 10 & -- \\
\hline \multirow[t]{2}{*}{ D3 } & $3 / 23 / 2010$ & 608 & 18 & 15 & 0.06 & 0.08 & 1.1 & 1.2 & 0.40 & 0.48 & 2.2 & 2.3 & 19 \\
\hline & $3 / 23 / 2010$ & 605 & 20 & 15 & 0.06 & 0.09 & 1.1 & 1.2 & 0.41 & 0.48 & 2.1 & 2.3 & 20 \\
\hline \multirow[t]{2}{*}{ E2 } & $5 / 4 / 2010$ & 805 & $<5$ & 20 & $<0.03$ & $<0.03$ & 16 & 17 & $<0.01$ & $<0.01$ & 16 & 16 & -- \\
\hline & $5 / 4 / 2010$ & 804 & $<5$ & 20 & $<0.03$ & $<0.03$ & 16 & 16 & $<0.01$ & $<0.01$ & 16 & 16 & -- \\
\hline \multirow[t]{2}{*}{ E3 } & $5 / 4 / 2010$ & 979 & $<5$ & 22 & $<0.03$ & $<0.03$ & 11 & 12 & $<0.01$ & $<0.01$ & 12 & 12 & -- \\
\hline & $5 / 4 / 2010$ & 979 & $<5$ & 22 & $<0.03$ & $<0.03$ & 12 & 12 & $<0.01$ & $<0.01$ & 12 & 12 & -- \\
\hline \multirow[t]{2}{*}{ U1 } & $3 / 21 / 2011$ & 4,520 & 55 & 152 & -- & 192 & -- & 0.23 & -- & 20 & -- & 344 & -- \\
\hline & $3 / 21 / 2011$ & 4,510 & 38 & 159 & -- & 191 & -- & 0.25 & -- & 20 & -- & 350 & -- \\
\hline \multirow[t]{2}{*}{$\mathrm{U} 2$} & $3 / 21 / 2011$ & 1,010 & 21 & 50 & 19 & 19 & 0.04 & 0.45 & 3.9 & 4.3 & 35 & 37 & -- \\
\hline & $3 / 21 / 2011$ & 1,010 & 17 & 50 & 19 & 20 & 0.04 & 0.43 & 3.9 & 4.9 & 34 & 39 & -- \\
\hline \multirow[t]{2}{*}{ D1 } & 4/13/2011 & 576 & 50 & 5 & 0.48 & 0.59 & 0.38 & 0.44 & 0.41 & 0.44 & 1.6 & 1.9 & -- \\
\hline & 4/13/2011 & 575 & 59 & 5 & 0.55 & 0.58 & 0.42 & 0.47 & 0.44 & 0.47 & 1.9 & 1.7 & 21 \\
\hline E1 & $4 / 13 / 2011$ & 314 & $<5$ & 6 & $<0.03$ & $<0.03$ & $<0.03$ & $<0.03$ & 0.09 & 0.11 & 1.4 & 1.4 & -- \\
\hline
\end{tabular}


Table 1-2. Quality assurance data collected at Discovery Farm monitoring sites, North Dakota, 2008-16. - Continued

$\left[\mu \mathrm{S} / \mathrm{cm}\right.$ at $25^{\circ} \mathrm{C}$, microsiemen per centimeter at 25 degrees Celsius; $\mathrm{mg} / \mathrm{L}$, milligram per liter; $\mathrm{N}$, nitrogen; P, phosphorus, $<$, less than; --, not available]

\begin{tabular}{|c|c|c|c|c|c|c|c|c|c|c|c|c|c|}
\hline Site & Date & $\begin{array}{c}\text { Specific } \\
\text { conduct- } \\
\text { ance, } \\
\text { laboratory, } \\
\text { in } \mu \mathrm{S} / \mathrm{cm} \text { at } \\
25^{\circ} \mathrm{C}\end{array}$ & $\begin{array}{c}\text { Suspended } \\
\text { solids, } \\
\text { in mg/L }\end{array}$ & $\begin{array}{c}\text { Chloride, } \\
\text { in mg/L }\end{array}$ & $\begin{array}{c}\text { Dissolved } \\
\text { (filtered) } \\
\text { ammonia, } \\
\text { in } \mathrm{mg} / \mathrm{L} \\
\text { as N }\end{array}$ & $\begin{array}{c}\text { Total } \\
\text { (unfiltered) } \\
\text { ammonia, } \\
\text { in mg/L } \\
\text { as N }\end{array}$ & $\begin{array}{c}\text { Dissolved } \\
\text { (filtered) } \\
\text { nitrate plus } \\
\text { nitrite, } \\
\text { in } \mathrm{mg} / \mathrm{L} \\
\text { as } \mathrm{N}\end{array}$ & $\begin{array}{c}\text { Total nitrate } \\
\text { plus nitrite } \\
\text { (unfiltered), } \\
\text { in } \mathrm{mg} / \mathrm{L} \\
\text { as N }\end{array}$ & $\begin{array}{c}\text { Dissolved } \\
\text { (filtered) } \\
\text { phosphorus, } \\
\text { in } \mathrm{mg} / \mathrm{L} \\
\text { as P }\end{array}$ & $\begin{array}{c}\text { Total } \\
\text { (unfiltered) } \\
\text { phosphorus, } \\
\text { in } \mathrm{mg} / \mathrm{L} \\
\text { as P }\end{array}$ & $\begin{array}{c}\text { Total } \\
\text { dissolved } \\
\text { (filtered) } \\
\text { nitrogen, } \\
\text { in } \mathrm{mg} / \mathrm{L} \\
\text { as } \mathrm{N}\end{array}$ & $\begin{array}{c}\text { Total } \\
\text { (unfiltered) } \\
\text { nitrogen, } \\
\text { in } \mathrm{mg} / \mathrm{L} \\
\text { as N }\end{array}$ & $\begin{array}{l}\text { Suspended- } \\
\text { sediment, } \\
\text { in } \mathrm{mg} / \mathrm{L}\end{array}$ \\
\hline \multicolumn{14}{|c|}{ Replicates-Continued } \\
\hline & 4/13/2011 & 311 & $<5$ & 6 & $<0.03$ & $<0.03$ & $<0.03$ & $<0.03$ & 0.07 & 0.09 & 1.2 & 1.3 & -- \\
\hline \multirow[t]{2}{*}{ D2 } & $4 / 13 / 2011$ & 996 & 100 & 24 & 0.52 & 0.53 & 2.56 & 2.7 & 0.55 & 0.63 & 4.0 & 3.8 & -- \\
\hline & 4/13/2011 & 988 & 300 & 24 & 0.54 & 0.51 & 2.7 & 2.9 & 0.54 & 0.66 & 4.1 & 4.0 & -- \\
\hline \multirow[t]{2}{*}{ E2 } & $4 / 13 / 2011$ & 672 & $<5$ & 12 & $<0.03$ & $<0.03$ & 1.0 & 1.0 & $<0.01$ & $<0.01$ & 10 & 10 & -- \\
\hline & $4 / 13 / 2011$ & 674 & $<5$ & 12 & $<0.03$ & $<0.03$ & 0.96 & 0.95 & $<0.01$ & $<0.01$ & 9.8 & 9.7 & -- \\
\hline \multirow[t]{2}{*}{ D3 } & $4 / 13 / 2011$ & 1,160 & 43 & 36 & 0.23 & 0.23 & 5.0 & 5.1 & 0.95 & 1.0 & 6.0 & 5.9 & 49 \\
\hline & $4 / 13 / 2011$ & 1,160 & 32 & 35 & 0.26 & 0.22 & 4.9 & 5.1 & 1.1 & 1.1 & 6.1 & 5.7 & 39 \\
\hline \multirow[t]{2}{*}{ E3 } & 4/13/2011 & 825 & $<5$ & 11 & $<0.03$ & $<0.03$ & 7.5 & 7.3 & 0.16 & 0.16 & 7.1 & 7.1 & -- \\
\hline & $4 / 13 / 2011$ & 825 & $<5$ & 11 & $<0.03$ & $<0.03$ & 7.0 & 6.3 & $<0.01$ & $<0.01$ & 7.7 & 6.8 & -- \\
\hline \multirow[t]{2}{*}{ E3 } & $4 / 18 / 2012$ & 768 & $<5$ & 17 & 0.03 & $<0.03$ & 7.5 & 7.8 & 0.07 & 0.07 & 7.6 & 7.9 & -- \\
\hline & $4 / 18 / 2012$ & 769 & $<5$ & 16 & $<0.03$ & $<0.03$ & 7.7 & 7.8 & 0.05 & 0.07 & 7.9 & 8.2 & -- \\
\hline \multirow[t]{2}{*}{ E1 } & $7 / 25 / 2012$ & 154 & 11 & 3 & 0.68 & 0.70 & 0.22 & 0.24 & 2.1 & 2.2 & 2.9 & 2.8 & 20 \\
\hline & $7 / 25 / 2012$ & 162 & 11 & 3 & 0.75 & 0.76 & 0.26 & 0.26 & 2.2 & 2.2 & 2.9 & 2.8 & 33 \\
\hline \multirow[t]{2}{*}{ U2 } & $4 / 4 / 2013$ & 392 & 43 & 5 & 0.74 & 0.79 & 2.8 & 2.8 & 0.98 & 1.1 & 5.2 & 5.2 & 16 \\
\hline & $4 / 4 / 2013$ & 387 & 5 & 5 & 0.72 & 0.77 & 2.8 & 2.8 & 0.96 & 1.1 & 5.2 & 5.3 & 18 \\
\hline \multirow[t]{2}{*}{ U3 } & $4 / 4 / 2013$ & 392 & $<5$ & 6 & 0.47 & 0.47 & 2.9 & 3.0 & 1.4 & 1.5 & 5.0 & 5.1 & 23 \\
\hline & 4/4/2013 & 392 & $<5$ & 6 & 0.47 & 0.43 & 2.8 & 3.2 & 1.4 & 1.6 & 5.1 & 5.3 & 27 \\
\hline \multirow[t]{2}{*}{ D3 } & $4 / 26 / 2013$ & 312 & $<5$ & 7 & 0.20 & 0.22 & 0.51 & 0.51 & 0.66 & 0.67 & 1.6 & 1.6 & 3 \\
\hline & $4 / 26 / 2013$ & 316 & $<5$ & 7 & 0.21 & 0.21 & 0.50 & 0.50 & 0.65 & 0.66 & 1.5 & 1.5 & 3 \\
\hline \multirow[t]{2}{*}{ E3 } & 4/30/2013 & 670 & $<5$ & 15 & $<0.03$ & $<0.03$ & 4.1 & 4.3 & 0.16 & 0.16 & 4.9 & 4.8 & -- \\
\hline & $4 / 30 / 2013$ & 669 & $<5$ & 15 & $<0.03$ & $<0.03$ & 4.2 & 4.3 & 0.17 & 0.16 & 5.0 & 4.9 & -- \\
\hline \multirow[t]{2}{*}{ E1 } & $3 / 11 / 2014$ & 268 & 12 & 17 & 1.9 & 2.0 & 2.0 & 2.1 & 1.5 & 1.6 & 7.5 & 8.3 & 15 \\
\hline & $3 / 11 / 2014$ & 279 & 11 & 18 & 2.1 & 2.2 & 2.0 & 2.1 & 1.6 & 1.8 & 7.9 & 9.2 & 16 \\
\hline \multirow[t]{2}{*}{ E3 } & 8/19/2014 & 790 & $<5$ & 18 & $<0.03$ & $<0.03$ & 6.5 & 6.4 & $<0.20$ & $<0.20$ & 6.8 & 6.9 & -- \\
\hline & 8/19/2014 & 790 & $<5$ & 18 & $<0.03$ & $<0.03$ & 6.5 & 6.5 & $<0.20$ & $<0.20$ & 6.8 & 6.9 & -- \\
\hline \multirow[t]{2}{*}{ E3 } & 4/7/2016 & 807 & 153 & 17 & 0.08 & $<0.03$ & 8.9 & 8.8 & $<0.20$ & 0.19 & 9.1 & 9.2 & -- \\
\hline & 4/7/2016 & 809 & 42 & 17 & $<0.03$ & $<0.03$ & 8.8 & 8.8 & $<0.20$ & $<0.20$ & 9.3 & 9.1 & -- \\
\hline
\end{tabular}


52 Runoff and Water-Quality Characteristics of Three Discovery Farms in North Dakota, 2008-16

Table 1-3. Monthly loads for monitoring sites at Underwood farm, North Dakota, 2008-15.

[N, nitrogen; P, phosphorus]

\begin{tabular}{|c|c|c|c|c|c|c|c|}
\hline \multirow[b]{2}{*}{ Year } & \multirow[b]{2}{*}{ Month } & \multirow[b]{2}{*}{$\begin{array}{l}\text { Flow volume, } \\
\text { in acre-feet }\end{array}$} & \multicolumn{5}{|c|}{ Monthly load, in pounds per month } \\
\hline & & & Chloride & $\begin{array}{l}\text { Total (unfiltered) } \\
\text { ammonia, as N }\end{array}$ & $\begin{array}{l}\text { Total (unfiltered) } \\
\text { nitrate plus nitrite, } \\
\text { as N }\end{array}$ & $\begin{array}{l}\text { Total (unfiltered) } \\
\text { phosphorus, as } \mathbf{P}\end{array}$ & $\begin{array}{l}\text { Suspended } \\
\text { sediment }\end{array}$ \\
\hline \multicolumn{8}{|c|}{ Site U1 } \\
\hline \multirow[t]{5}{*}{2008} & June & 0.7 & 463 & 7 & 9 & 54 & 1,039 \\
\hline & July & 0.0 & 3 & 0 & 0 & 0 & 10 \\
\hline & August & 0.1 & 10 & 0 & 1 & 1 & 47 \\
\hline & September & 0.0 & 0 & 0 & 0 & 0 & 0 \\
\hline & October & 0.0 & 0 & 0 & 0 & 0 & 0 \\
\hline \multirow[t]{8}{*}{2009} & March & 4.1 & 864 & 1,135 & 4 & 131 & 4,239 \\
\hline & April & 18 & 1,088 & 1,355 & 16 & 243 & 8,994 \\
\hline & May & 3 & 273 & 25 & 10 & 42 & 4,916 \\
\hline & June & 0.4 & 234 & 3 & 2 & 3 & 491 \\
\hline & July & 0.3 & 98 & 1 & 2 & 6 & 333 \\
\hline & August & 0.0 & 0 & 0 & 0 & 0 & 0 \\
\hline & September & 0.0 & 0 & 0 & 0 & 0 & 0 \\
\hline & October & 0.0 & 0 & 0 & 0 & 0 & 0 \\
\hline \multirow[t]{8}{*}{2010} & March & 15 & 5,535 & 2,898 & 35 & 932 & 15,276 \\
\hline & April & 1 & 165 & 95 & 1 & 40 & 1,889 \\
\hline & May & 1 & 300 & 11 & 8 & 36 & 7,720 \\
\hline & June & 2 & 391 & 13 & 25 & 53 & 6,857 \\
\hline & July & 0.1 & 13 & 7 & 1 & 2 & 273 \\
\hline & August & 0.4 & 78 & 58 & 4 & 12 & 1,189 \\
\hline & September & 1 & 249 & 196 & 12 & 37 & 3,461 \\
\hline & October & 0.0 & 0 & 0 & 0 & 0 & 0 \\
\hline \multirow[t]{8}{*}{2011} & March & 20 & 8,335 & 9,302 & 17 & 1,067 & 32,210 \\
\hline & April & 13 & 3,989 & 1,835 & 3 & 418 & 18,001 \\
\hline & May & 4.0 & 2,101 & 169 & 1 & 130 & 7,057 \\
\hline & June & 2 & 923 & 30 & 13 & 83 & 3,467 \\
\hline & July & 2 & 562 & 14 & 21 & 54 & 6,027 \\
\hline & August & 0.6 & 139 & 3 & 5 & 9 & 2,398 \\
\hline & September & 0.2 & 48 & 1 & 2 & 4 & 650 \\
\hline & October & 0.0 & 0 & 0 & 0 & 0 & 0 \\
\hline \multirow[t]{9}{*}{2012} & March & 1 & 589 & 26 & 43 & 46 & 5,744 \\
\hline & April & 0.4 & 433 & 7 & 5 & 20 & 825 \\
\hline & May & 0.2 & 226 & 3 & 2 & 10 & 366 \\
\hline & June & 0.2 & 159 & 2 & 2 & 6 & 129 \\
\hline & July & 0.4 & 334 & 5 & 5 & 14 & 95 \\
\hline & August & 0.0 & 0 & 0 & 0 & 0 & 0 \\
\hline & September & 0.0 & 0 & 0 & 0 & 0 & 0 \\
\hline & October & 0.1 & 63 & 3 & 1 & 4 & 18 \\
\hline & November & 0.1 & 62 & 3 & 1 & 4 & 18 \\
\hline
\end{tabular}


Table 1-3. Monthly loads for monitoring sites at Underwood farm, North Dakota, 2008-15.—Continued

[N, nitrogen; $\mathrm{P}$, phosphorus]

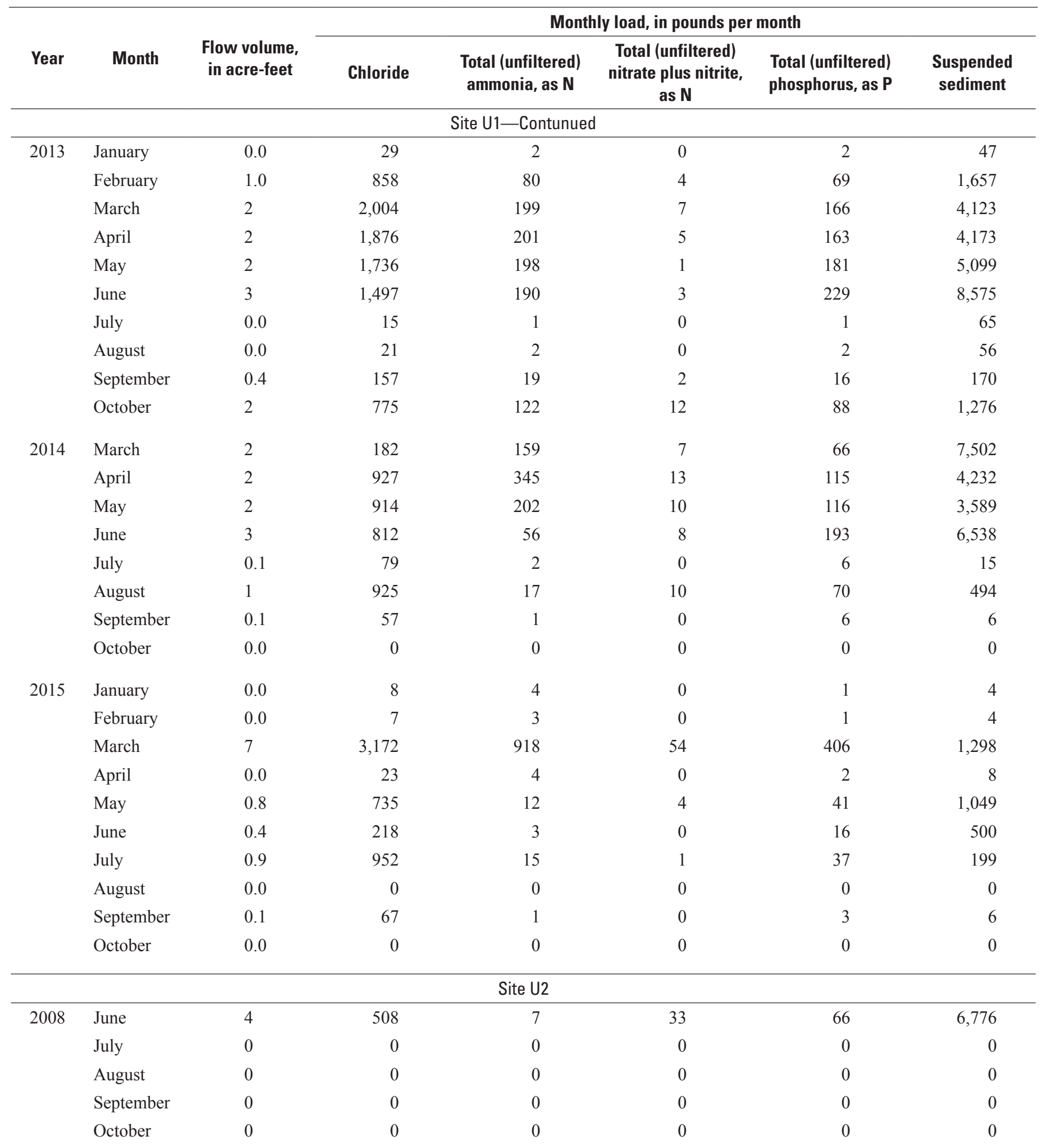


54 Runoff and Water-Quality Characteristics of Three Discovery Farms in North Dakota, 2008-16

Table 1-3. Monthly loads for monitoring sites at Underwood farm, North Dakota, 2008-15.—Continued

[N, nitrogen; P, phosphorus]

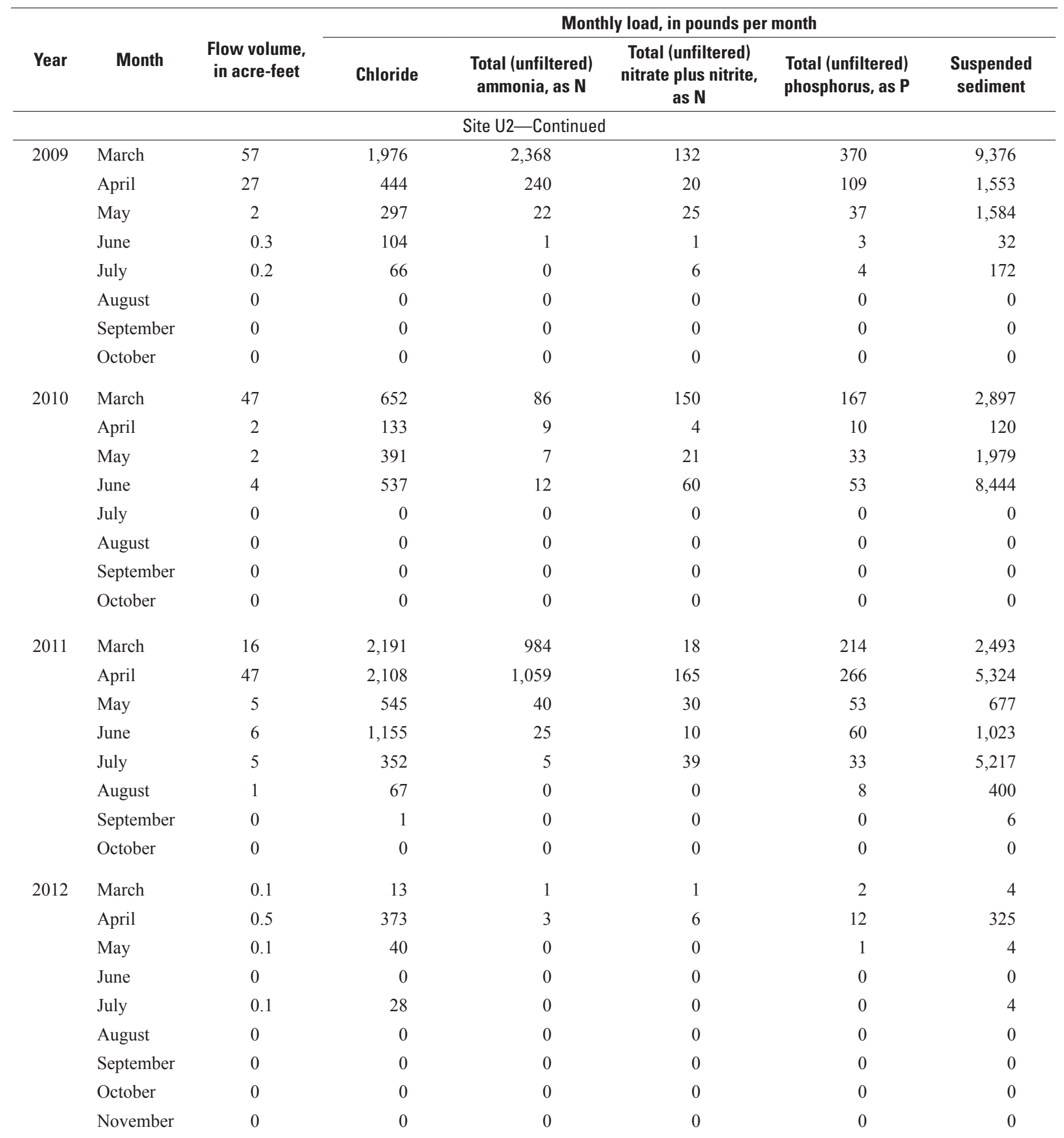


Table 1-3. Monthly loads for monitoring sites at Underwood farm, North Dakota, 2008-15.-Continued

[N, nitrogen; $\mathrm{P}$, phosphorus]

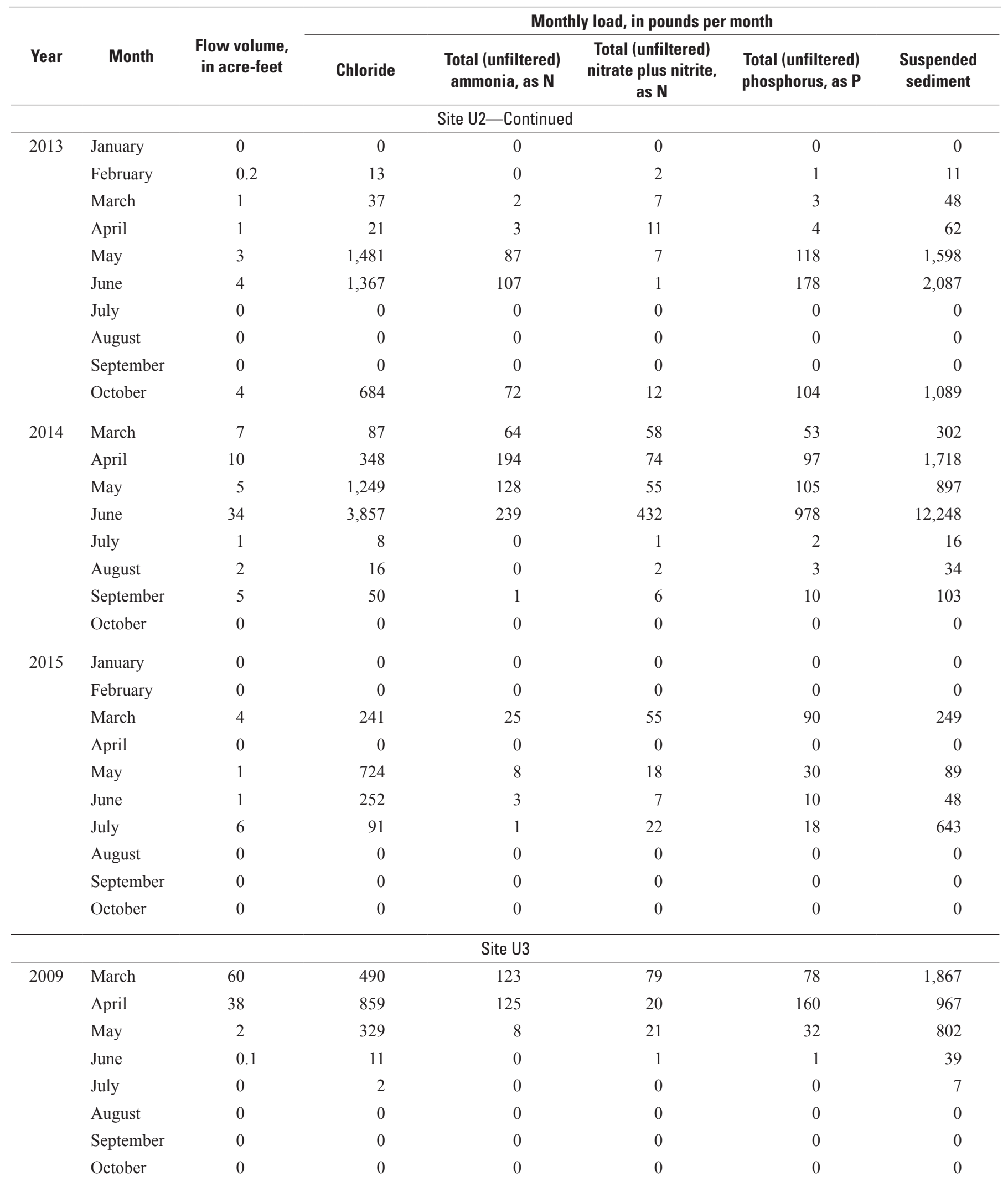


Table 1-3. Monthly loads for monitoring sites at Underwood farm, North Dakota, 2008-15.-Continued

[N, nitrogen; P, phosphorus]

\begin{tabular}{|c|c|c|c|c|c|c|c|}
\hline \multirow[b]{2}{*}{ Year } & \multirow[b]{2}{*}{ Month } & \multirow[b]{2}{*}{$\begin{array}{l}\text { Flow volume, } \\
\text { in acre-feet }\end{array}$} & \multicolumn{5}{|c|}{ Monthly load, in pounds per month } \\
\hline & & & Chloride & $\begin{array}{l}\text { Total (unfiltered) } \\
\text { ammonia, as N }\end{array}$ & $\begin{array}{c}\text { Total (unfiltered) } \\
\text { nitrate plus nitrite, } \\
\text { as } \mathrm{N}\end{array}$ & $\begin{array}{l}\text { Total (unfiltered) } \\
\text { phosphorus, as P }\end{array}$ & $\begin{array}{l}\text { Suspended } \\
\text { sediment }\end{array}$ \\
\hline \multicolumn{8}{|c|}{ Site U3-Continued } \\
\hline \multirow[t]{6}{*}{2010} & March & 66 & 1,165 & 131 & 220 & 309 & 3,169 \\
\hline & April & 6 & 1,119 & 3 & 21 & 27 & 418 \\
\hline & June & 8 & 1,663 & 3 & 68 & 63 & 638 \\
\hline & July & 0 & 1 & 0 & 0 & 0 & 0 \\
\hline & August & 0 & 0 & 0 & 0 & 0 & 0 \\
\hline & September & 0.3 & 64 & 1 & 1 & 2 & 83 \\
\hline \multirow{6}{*}{2011} & May & 10 & 1,383 & 31 & 25 & 92 & 576 \\
\hline & June & 10 & 760 & 4 & 17 & 76 & 337 \\
\hline & July & 7 & 325 & 1 & 5 & 36 & 504 \\
\hline & August & 2 & 138 & 0 & 2 & 12 & 37 \\
\hline & September & 0 & 0 & 0 & 0 & 0 & 0 \\
\hline & October & 0 & 0 & 0 & 0 & 0 & 0 \\
\hline \multirow[t]{3}{*}{2012} & March & 0.1 & 19 & 0 & 3 & 1 & 6 \\
\hline & April & 1 & 289 & 0 & 5 & 2 & 133 \\
\hline & November & 0 & 0 & 0 & 0 & 0 & 0 \\
\hline \multirow[t]{10}{*}{2013} & January & 0 & 0 & 0 & 0 & 0 & 0 \\
\hline & February & 0 & 0 & 0 & 0 & 0 & 0 \\
\hline & March & 0 & 0 & 0 & 0 & 0 & 0 \\
\hline & April & 1 & 20 & 0 & 7 & 3 & 60 \\
\hline & May & 4 & 1,380 & 18 & 10 & 75 & 1,384 \\
\hline & June & 6 & 1,474 & 25 & 8 & 114 & 565 \\
\hline & July & 0 & 0 & 0 & 0 & 0 & 0 \\
\hline & August & 0 & 0 & 0 & 0 & 0 & 0 \\
\hline & September & 0 & 0 & 0 & 0 & 0 & 0 \\
\hline & October & 5 & 382 & 96 & 138 & 70 & 572 \\
\hline
\end{tabular}


Table 1-3. Monthly loads for monitoring sites at Underwood farm, North Dakota, 2008-15. - Continued

$[\mathrm{N}$, nitrogen; P, phosphorus $]$

\begin{tabular}{|c|c|c|c|c|c|c|c|}
\hline \multirow[b]{2}{*}{ Year } & \multirow[b]{2}{*}{ Month } & \multirow[b]{2}{*}{$\begin{array}{l}\text { Flow volume, } \\
\text { in acre-feet }\end{array}$} & \multicolumn{5}{|c|}{ Monthly load, in pounds per month } \\
\hline & & & Chloride & $\begin{array}{l}\text { Total (unfiltered) } \\
\text { ammonia, as N }\end{array}$ & $\begin{array}{l}\text { Total (unfiltered) } \\
\text { nitrate plus nitrite, } \\
\text { as N }\end{array}$ & $\begin{array}{l}\text { Total (unfiltered) } \\
\text { phosphorus, as } P\end{array}$ & $\begin{array}{c}\text { Suspended } \\
\text { sediment }\end{array}$ \\
\hline \multicolumn{8}{|c|}{ Site U3-Continued } \\
\hline \multirow[t]{8}{*}{2014} & March & 14 & 493 & 127 & 100 & 168 & 681 \\
\hline & April & 19 & 815 & 89 & 161 & 133 & 3,792 \\
\hline & May & 5 & 1,176 & 18 & 52 & 82 & 1,097 \\
\hline & June & 37 & 2,306 & 20 & 308 & 240 & 6,284 \\
\hline & July & 1 & 34 & 0 & 2 & 4 & 30 \\
\hline & August & 1 & 343 & 0 & 5 & 8 & 54 \\
\hline & September & 0 & 0 & 0 & 0 & 0 & 0 \\
\hline & October & 0 & 0 & 0 & 0 & 0 & 0 \\
\hline \multirow[t]{10}{*}{2015} & January & 0 & 0 & 0 & 0 & 0 & 0 \\
\hline & February & 0 & 0 & 0 & 0 & 0 & 0 \\
\hline & March & 10 & 443 & 38 & 99 & 211 & 410 \\
\hline & April & 0 & 4 & 0 & 0 & 0 & 1 \\
\hline & May & 3 & 1,041 & 1 & 20 & 24 & 88 \\
\hline & June & 1 & 351 & 1 & 3 & 9 & 143 \\
\hline & July & 21 & 326 & 21 & 110 & 131 & 2,916 \\
\hline & August & 0 & 0 & 0 & 0 & 0 & 0 \\
\hline & September & 0 & 0 & 0 & 0 & 0 & 0 \\
\hline & October & 0 & 0 & 0 & 0 & 0 & 0 \\
\hline
\end{tabular}


Table 1-4. Monthly loads for monitoring sites at Embden farm, North Dakota, 2009-16.

[N, nitrogen; $\mathrm{P}$, phosphorus]

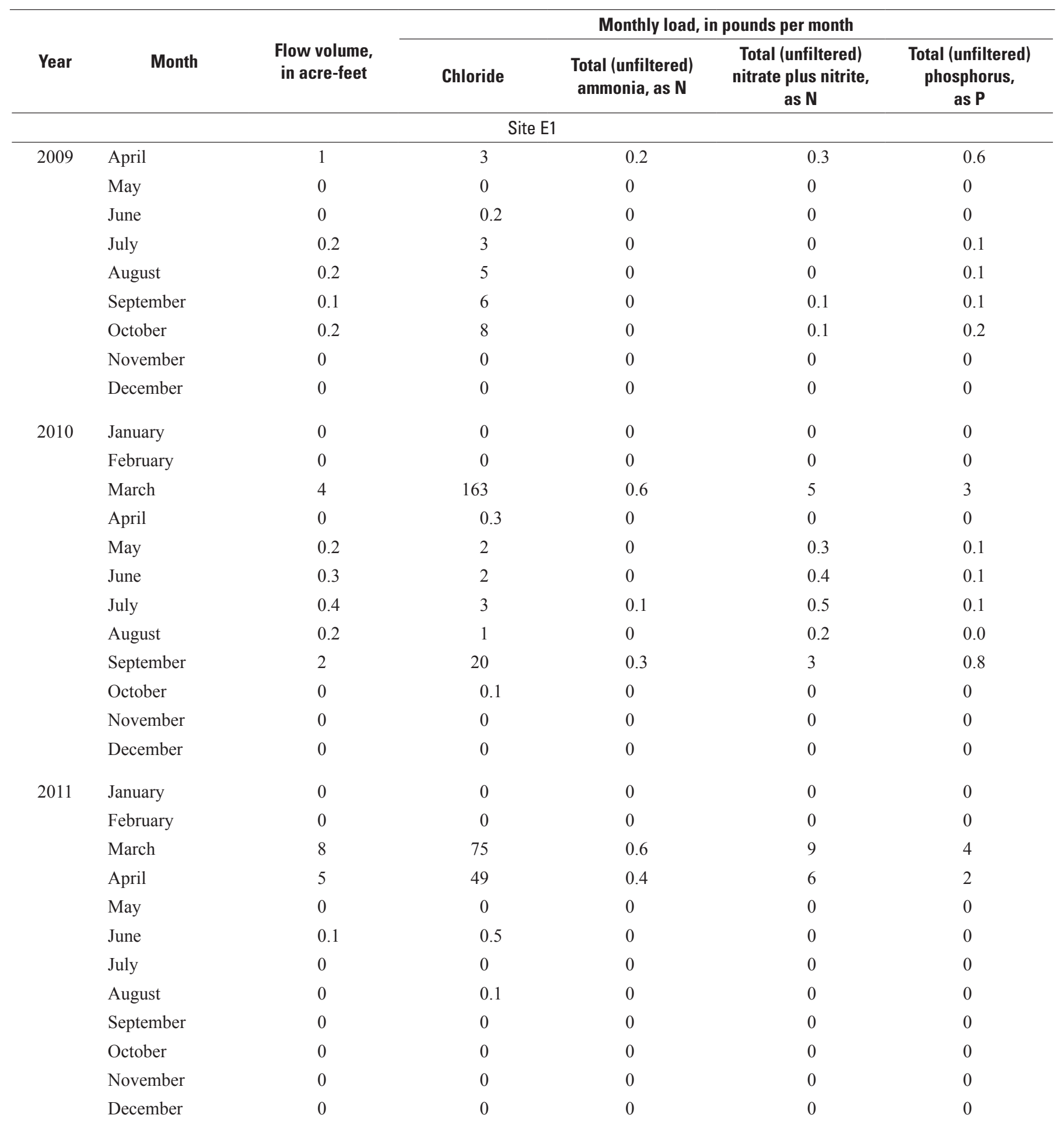


Table 1-4. Monthly loads for monitoring sites at Embden farm, North Dakota, 2009-16. - Continued

$[\mathrm{N}$, nitrogen; $\mathrm{P}$, phosphorus $]$

\begin{tabular}{|c|c|c|c|c|c|c|}
\hline \multirow[b]{2}{*}{ Year } & \multirow[b]{2}{*}{ Month } & \multirow[b]{2}{*}{$\begin{array}{l}\text { Flow volume, } \\
\text { in acre-feet }\end{array}$} & \multicolumn{4}{|c|}{ Monthly load, in pounds per month } \\
\hline & & & Chloride & $\begin{array}{l}\text { Total (unfiltered) } \\
\text { ammonia, as } \mathbf{N}\end{array}$ & $\begin{array}{c}\text { Total (unfiltered) } \\
\text { nitrate plus nitrite, } \\
\text { as } \mathbf{N}\end{array}$ & $\begin{array}{c}\text { Total (unfiltered) } \\
\text { phosphorus, } \\
\text { as P }\end{array}$ \\
\hline \multicolumn{7}{|c|}{ Site E1-Continued } \\
\hline \multirow[t]{8}{*}{2012} & January & 0 & 0 & 0 & 0 & 0 \\
\hline & February & 0 & 0 & 0 & 0 & 0 \\
\hline & April & 0 & 0.4 & 0.1 & 0 & 0.2 \\
\hline & May & 0 & 0.3 & 0.1 & 0 & 0.2 \\
\hline & June & 0 & 0.2 & 0.1 & 0 & 0.1 \\
\hline & July & 0.1 & 0.6 & 0.1 & 0 & 0.4 \\
\hline & November & 0.1 & 0.6 & 0.1 & 0 & 0.4 \\
\hline & December & 0 & 0 & 0 & 0 & 0 \\
\hline \multirow[t]{6}{*}{2013} & January & 0 & 0 & 0 & 0 & 0 \\
\hline & February & 0 & 0 & 0 & 0 & 0 \\
\hline & March & 0 & 0 & 0 & 0 & 0 \\
\hline & April & 0 & 0 & 0 & 0 & 0 \\
\hline & May & 0 & 0.1 & 0 & 0 & 0 \\
\hline & June & 0 & 0.1 & 0.1 & 0 & 0.1 \\
\hline \multirow[t]{12}{*}{2014} & January & 0 & 0 & 0 & 0 & 0 \\
\hline & February & 0 & 0 & 0 & 0 & 0 \\
\hline & March & 0.2 & 11 & 1 & 1 & 1 \\
\hline & April & 0.1 & 0.7 & 0 & 0 & 0.1 \\
\hline & May & 0 & 0 & 0 & 0 & 0 \\
\hline & June & 0 & 0 & 0 & 0 & 0 \\
\hline & July & 0 & 0 & 0 & 0 & 0 \\
\hline & August & 0.3 & 2 & 0.2 & 0 & 0.4 \\
\hline & September & 0.2 & 2 & 0.2 & 0 & 0.4 \\
\hline & October & 0 & 0 & 0 & 0 & 0 \\
\hline & November & 0 & 0 & 0 & 0 & 0 \\
\hline & December & 0 & 0 & 0 & 0 & 0 \\
\hline
\end{tabular}


Table 1-4. Monthly loads for monitoring sites at Embden farm, North Dakota, 2009-16._Continued

[N, nitrogen; $\mathrm{P}$, phosphorus]

\begin{tabular}{|c|c|c|c|c|c|c|}
\hline \multirow[b]{2}{*}{ Year } & \multirow[b]{2}{*}{ Month } & \multirow[b]{2}{*}{$\begin{array}{l}\text { Flow volume, } \\
\text { in acre-feet }\end{array}$} & \multicolumn{4}{|c|}{ Monthly load, in pounds per month } \\
\hline & & & Chloride & $\begin{array}{l}\text { Total (unfiltered) } \\
\text { ammonia, as } \mathbf{N}\end{array}$ & $\begin{array}{c}\text { Total (unfiltered) } \\
\text { nitrate plus nitrite, } \\
\text { as } \mathrm{N}\end{array}$ & $\begin{array}{c}\text { Total (unfiltered) } \\
\text { phosphorus, } \\
\text { as P }\end{array}$ \\
\hline \multicolumn{7}{|c|}{ Site E1-Continued } \\
\hline \multirow[t]{8}{*}{2015} & January & 0 & 0 & 0 & 0 & 0 \\
\hline & February & 0 & 0 & 0 & 0 & 0 \\
\hline & April & 0 & 0 & 0 & 0 & 0 \\
\hline & May & 0.1 & 2 & 0.8 & 0.1 & 0.7 \\
\hline & June & 0.1 & 1 & 0.5 & 0.1 & 0.4 \\
\hline & July & 0 & 0.4 & 0.1 & 0 & 0.1 \\
\hline & November & 0 & 0 & 0 & 0 & 0 \\
\hline & December & 0 & 0 & 0 & 0 & 0 \\
\hline \multirow[t]{6}{*}{2016} & January & 0 & 0 & 0 & 0 & 0 \\
\hline & February & 0 & 0 & 0 & 0 & 0 \\
\hline & March & 0 & 0 & 0 & 0 & 0 \\
\hline & April & 0 & 0 & 0 & 0 & 0 \\
\hline & May & 0 & 0 & 0 & 0 & 0 \\
\hline & June & 0 & 0 & 0 & 0 & 0 \\
\hline \multirow{5}{*}{2009} & August & 0.1 & 8 & 0.0 & 7 & 0.1 \\
\hline & September & 0 & 3 & 0.0 & 2 & 0.0 \\
\hline & October & 6 & 400 & 3.7 & 229 & 0.5 \\
\hline & November & 5 & 358 & 1.2 & 190 & 0.4 \\
\hline & December & 1 & 111 & 0.5 & 55 & 0.1 \\
\hline
\end{tabular}


Table 1-4. Monthly loads for monitoring sites at Embden farm, North Dakota, 2009-16. - Continued

$[\mathrm{N}$, nitrogen; $\mathrm{P}$, phosphorus $]$

\begin{tabular}{|c|c|c|c|c|c|c|}
\hline \multirow[b]{2}{*}{ Year } & \multirow[b]{2}{*}{ Month } & \multirow[b]{2}{*}{$\begin{array}{l}\text { Flow volume, } \\
\text { in acre-feet }\end{array}$} & \multicolumn{4}{|c|}{ Monthly load, in pounds per month } \\
\hline & & & Chloride & $\begin{array}{l}\text { Total (unfiltered) } \\
\text { ammonia, as } \mathbf{N}\end{array}$ & $\begin{array}{l}\text { Total (unfiltered) } \\
\text { nitrate plus nitrite, } \\
\text { as } \mathbf{N}\end{array}$ & $\begin{array}{c}\text { Total (unfiltered) } \\
\text { phosphorus, } \\
\text { as P }\end{array}$ \\
\hline \multicolumn{7}{|c|}{ Site E2-Continued } \\
\hline \multirow[t]{8}{*}{2010} & January & 2 & 159 & 0.8 & 71 & 0.2 \\
\hline & February & 1 & 111 & 0.6 & 46 & 0.2 \\
\hline & April & 14 & 728 & 14 & 562 & 0.3 \\
\hline & May & 18 & 929 & 9 & 730 & 0.3 \\
\hline & June & 13 & 625 & 7 & 479 & 0.2 \\
\hline & July & 14 & 445 & 7 & 465 & 0.6 \\
\hline & November & 9 & 247 & 3 & 236 & 1 \\
\hline & December & 5 & 134 & 1 & 122 & 0.9 \\
\hline \multirow[t]{6}{*}{2011} & January & 4 & 107 & 0.8 & 94 & 0.9 \\
\hline & February & 4 & 107 & 0.6 & 89 & 1 \\
\hline & March & 16 & 407 & 2 & 318 & 5 \\
\hline & April & 62 & 1,847 & 5 & 1,139 & 15 \\
\hline & May & 17 & 567 & 6 & 533 & 7 \\
\hline & June & 28 & 937 & 2 & 1,024 & 9 \\
\hline \multirow[t]{12}{*}{2012} & January & 0 & 0 & 0 & 0 & 0 \\
\hline & February & 0 & 0 & 0 & 0 & 0 \\
\hline & March & 0.4 & 14 & 0 & 18 & 0 \\
\hline & April & 0 & 0 & 0 & 0 & 0 \\
\hline & May & 0 & 0.1 & 0 & 0.2 & 0 \\
\hline & June & 0 & 0.5 & 0 & 0.7 & 0 \\
\hline & July & 0 & 1 & 0 & 2 & 0 \\
\hline & August & 0 & 0 & 0 & 0 & 0 \\
\hline & September & 0 & 0 & 0 & 0 & 0 \\
\hline & October & 0 & 0 & 0 & 0 & 0 \\
\hline & November & 0 & 0 & 0 & 0 & 0 \\
\hline & December & 0 & 0 & 0 & 0 & 0 \\
\hline
\end{tabular}


Table 1-4. Monthly loads for monitoring sites at Embden farm, North Dakota, 2009-16.-Continued

[N, nitrogen; $\mathrm{P}$, phosphorus]

\begin{tabular}{|c|c|c|c|c|c|c|}
\hline \multirow[b]{2}{*}{ Year } & \multirow[b]{2}{*}{ Month } & \multirow[b]{2}{*}{$\begin{array}{l}\text { Flow volume, } \\
\text { in acre-feet }\end{array}$} & \multicolumn{4}{|c|}{ Monthly load, in pounds per month } \\
\hline & & & Chloride & $\begin{array}{l}\text { Total (unfiltered) } \\
\text { ammonia, as } \mathbf{N}\end{array}$ & $\begin{array}{l}\text { Total (unfiltered) } \\
\text { nitrate plus nitrite, } \\
\text { as } \mathbf{N}\end{array}$ & $\begin{array}{c}\text { Total (unfiltered) } \\
\text { phosphorus, } \\
\text { as } \mathbf{P}\end{array}$ \\
\hline \multicolumn{7}{|c|}{ Site E2-Continued } \\
\hline \multirow[t]{8}{*}{2013} & January & 0 & 0 & 0 & 0 & 0 \\
\hline & February & 0 & 0 & 0 & 0 & 0 \\
\hline & April & 1 & 18 & 3 & 12 & 3 \\
\hline & May & 0 & 0.3 & 0.1 & 0.1 & 0.1 \\
\hline & June & 0.6 & 7 & 2 & 2 & 2 \\
\hline & July & 0 & 0.4 & 0.1 & 0.1 & 0.1 \\
\hline & November & 0 & 0.2 & 0 & 0 & 0.1 \\
\hline & December & 0 & 0 & 0 & 0 & 0 \\
\hline \multirow[t]{6}{*}{2014} & January & 0 & 0 & 0 & 0 & 0 \\
\hline & February & 0 & 0 & 0 & 0 & 0 \\
\hline & March & 0 & 0 & 0 & 0 & 0 \\
\hline & April & 1 & 9 & 0.6 & 2 & 2 \\
\hline & May & 0.1 & 3 & 0.1 & 0.9 & 0.1 \\
\hline & June & 0.2 & 8 & 0.2 & 2 & 0.1 \\
\hline \multirow[t]{12}{*}{2015} & January & 0 & 0 & 0 & 0 & 0 \\
\hline & February & 0 & 0 & 0 & 0 & 0 \\
\hline & March & 0.8 & 15 & 4 & 1 & 4 \\
\hline & April & 0 & 0 & 0 & 0 & 0 \\
\hline & May & 0.3 & 11 & 0.3 & 4 & 0.2 \\
\hline & June & 0.3 & 10 & 0.3 & 2 & 0.2 \\
\hline & July & 0 & 0.6 & 0 & 0.1 & 0 \\
\hline & August & 0 & 0 & 0 & 0 & 0 \\
\hline & September & 0 & 0 & 0 & 0 & 0 \\
\hline & October & 0 & 0.2 & 0 & 0 & 0 \\
\hline & November & 0 & 0 & 0 & 0 & 0 \\
\hline & December & 0 & 0 & 0 & 0 & 0 \\
\hline
\end{tabular}


Table 1-4. Monthly loads for monitoring sites at Embden farm, North Dakota, 2009-16. - Continued

$[\mathrm{N}$, nitrogen; $\mathrm{P}$, phosphorus $]$




Table 1-4. Monthly loads for monitoring sites at Embden farm, North Dakota, 2009-16._Continued

[N, nitrogen; $\mathrm{P}$, phosphorus]

\begin{tabular}{|c|c|c|c|c|c|c|}
\hline \multirow[b]{2}{*}{ Year } & \multirow[b]{2}{*}{ Month } & \multirow[b]{2}{*}{$\begin{array}{l}\text { Flow volume, } \\
\text { in acre-feet }\end{array}$} & \multicolumn{4}{|c|}{ Monthly load, in pounds per month } \\
\hline & & & Chloride & $\begin{array}{l}\text { Total (unfiltered) } \\
\text { ammonia, as } \mathbf{N}\end{array}$ & $\begin{array}{l}\text { Total (unfiltered) } \\
\text { nitrate plus nitrite, } \\
\text { as N }\end{array}$ & $\begin{array}{c}\text { Total (unfiltered) } \\
\text { phosphorus, } \\
\text { as P }\end{array}$ \\
\hline \multicolumn{7}{|c|}{ Site E3-Continued } \\
\hline \multirow[t]{8}{*}{2011} & January & 3 & 123 & 0.8 & 79 & 0.2 \\
\hline & February & 3 & 124 & 0.6 & 82 & 0.2 \\
\hline & April & 65 & 2,126 & 5 & 1,373 & 9 \\
\hline & May & 13 & 471 & 1 & 348 & 5 \\
\hline & June & 26 & 905 & 2 & 655 & 11 \\
\hline & July & 2 & 69 & 0.2 & 50 & 0.6 \\
\hline & November & 0 & 0 & 0 & 0 & 0 \\
\hline & December & 0 & 0 & 0 & 0 & 0 \\
\hline \multirow[t]{6}{*}{2012} & January & 0 & 0 & 0 & 0 & 0 \\
\hline & February & 0 & 0 & 0 & 0 & 0 \\
\hline & March & 0.2 & 10 & 0 & 5 & 0.1 \\
\hline & April & 1 & 61 & 0.1 & 31 & 0.3 \\
\hline & May & 2 & 80 & 0.2 & 49 & 0.1 \\
\hline & June & 2 & 59 & 0.1 & 40 & 0 \\
\hline \multirow[t]{12}{*}{2013} & January & 0 & 0 & 0 & 0 & 0 \\
\hline & February & 0 & 0 & 0 & 0 & 0 \\
\hline & March & 0 & 0 & 0 & 0 & 0 \\
\hline & April & 0.9 & 31 & 0.1 & 7 & 0.4 \\
\hline & May & 2 & 81 & 0.1 & 35 & 0.3 \\
\hline & June & 13 & 713 & 1 & 547 & 7 \\
\hline & July & 0.8 & 47 & 0.1 & 34 & 1 \\
\hline & August & 0 & 0 & 0 & 0 & 0 \\
\hline & September & 0 & 0 & 0 & 0 & 0 \\
\hline & October & 0.5 & 29 & 0 & 11 & 0 \\
\hline & November & 0.3 & 15 & 0 & 6 & 0 \\
\hline & December & 0 & 0 & 0 & 0 & 0 \\
\hline
\end{tabular}


Table 1-4. Monthly loads for monitoring sites at Embden farm, North Dakota, 2009-16. - Continued

[N, nitrogen; $\mathrm{P}$, phosphorus]

\begin{tabular}{|c|c|c|c|c|c|c|}
\hline \multirow[b]{2}{*}{ Year } & \multirow[b]{2}{*}{ Month } & \multirow[b]{2}{*}{$\begin{array}{l}\text { Flow volume, } \\
\text { in acre-feet }\end{array}$} & \multicolumn{4}{|c|}{ Monthly load, in pounds per month } \\
\hline & & & Chloride & $\begin{array}{l}\text { Total (unfiltered) } \\
\text { ammonia, as N }\end{array}$ & $\begin{array}{l}\text { Total (unfiltered) } \\
\text { nitrate plus nitrite, } \\
\text { as N }\end{array}$ & $\begin{array}{l}\text { Total (unfiltered) } \\
\text { phosphorus, } \\
\text { as P }\end{array}$ \\
\hline \multicolumn{7}{|c|}{ Site E3-Continued } \\
\hline \multirow[t]{12}{*}{2014} & January & 0 & 0 & 0 & 0 & 0 \\
\hline & February & 0 & 0 & 0 & 0 & 0 \\
\hline & March & 0 & 0 & 0 & 0 & 0 \\
\hline & April & 0.8 & 15 & 0.1 & 11 & 0.1 \\
\hline & May & 8 & 279 & 0.6 & 196 & 0.4 \\
\hline & June & 11 & 504 & 8 & 344 & 5 \\
\hline & July & 0.4 & 19 & 0.3 & 10 & 0.2 \\
\hline & August & 3 & 129 & 0.4 & 71 & 0.3 \\
\hline & September & 10 & 366 & 6 & 221 & 7 \\
\hline & October & 0.4 & 22 & 0.2 & 10 & 0.1 \\
\hline & November & 0.2 & 11 & 0 & 5 & 0 \\
\hline & December & 0 & 1 & 0 & 0.5 & 0 \\
\hline \multirow[t]{12}{*}{2015} & January & 0 & 1 & 0 & 0.4 & 0 \\
\hline & February & 0 & 0.0 & 0 & 0 & 0 \\
\hline & March & 0 & 0.4 & 0 & 0.1 & 0 \\
\hline & April & 0.2 & 8 & 0.1 & 3.0 & 0.1 \\
\hline & May & 15 & 752 & 19 & 450 & 5 \\
\hline & June & 11 & 568 & 2 & 353 & 0.9 \\
\hline & July & 0.4 & 22 & 0 & 13 & 0 \\
\hline & August & 0 & 0.1 & 0 & 0.1 & 0 \\
\hline & September & 0 & 0 & 0 & 0.0 & 0 \\
\hline & October & 0 & 1 & 0 & 0.6 & 0 \\
\hline & November & 0 & 0.7 & 0 & 0.4 & 0 \\
\hline & December & 0 & 0.1 & 0 & 0.1 & 0 \\
\hline \multirow[t]{9}{*}{2016} & January & 0 & 0 & 0 & 0 & 0 \\
\hline & February & 0.5 & 26 & 0 & 13 & 0 \\
\hline & March & 2 & 76 & 0.1 & 37 & 0.1 \\
\hline & April & 3 & 141 & 0.3 & 90 & 0.5 \\
\hline & May & 4 & 233 & 1 & 151 & 1 \\
\hline & June & 5 & 280 & 1 & 212 & 0.3 \\
\hline & July & 1 & 76 & 0.3 & 54 & 0.1 \\
\hline & August & 0 & 0.3 & 0 & 0.2 & 0 \\
\hline & September & 0 & 0.2 & 0 & 0.2 & 0 \\
\hline
\end{tabular}


Table 1-5. Monthly loads for monitoring sites at Dazey farm, North Dakota, 2010-15.

[N, nitrogen; $\mathrm{P}$, phosphorus]

\begin{tabular}{|c|c|c|c|c|c|c|c|}
\hline \multirow[b]{2}{*}{ Year } & \multirow[b]{2}{*}{ Month } & \multirow[b]{2}{*}{$\begin{array}{l}\text { Flow volume, } \\
\text { in acre-feet }\end{array}$} & \multicolumn{5}{|c|}{ Load, in pounds per month } \\
\hline & & & Chloride & $\begin{array}{l}\text { Total (unfiltered) } \\
\text { ammonia, } \\
\text { as } \mathbf{N}\end{array}$ & $\begin{array}{l}\text { Total (unfiltered) } \\
\text { nitrate plus nitrite, } \\
\text { as } \mathrm{N}\end{array}$ & $\begin{array}{l}\text { Total (unfiltered) } \\
\text { phosphorus, } \\
\text { as } \mathrm{P}\end{array}$ & $\begin{array}{c}\text { Suspended } \\
\text { sediment }\end{array}$ \\
\hline \multicolumn{8}{|c|}{ Site D1 } \\
\hline \multirow[t]{6}{*}{2013} & March & 1 & 0 & 0 & 0 & 0 & 1 \\
\hline & April & 23 & 0.6 & 0.1 & 0.3 & 0.2 & 23 \\
\hline & June & 19 & 0.2 & 0.0 & 0.0 & 0.0 & 19 \\
\hline & July & 0.0 & 0.0 & 0.0 & 0.0 & 0.0 & 0.0 \\
\hline & August & 0.0 & 0.0 & 0.0 & 0.0 & 0.0 & 0.0 \\
\hline & September & 9 & 0.1 & 0.0 & 0.1 & 0.0 & 9.1 \\
\hline \multirow{6}{*}{2014} & May & 35 & 1.8 & 0.0 & 0.2 & 0.1 & 35.4 \\
\hline & June & 383 & 5.8 & 0.2 & 1.6 & 1.1 & 382.7 \\
\hline & July & 6 & 0.0 & 0.0 & 0.0 & 0.0 & 5.6 \\
\hline & August & 299 & 2.2 & 0.2 & 2.5 & 1.1 & 298.7 \\
\hline & September & 7 & 0.1 & 0.0 & 0.1 & 0.0 & 7.2 \\
\hline & October & 0 & 0.0 & 0.0 & 0.0 & 0.0 & 0.0 \\
\hline \multirow[t]{2}{*}{2015} & March & 90 & 0.1 & 4.4 & 1.2 & 90.2 & $1,298.0$ \\
\hline & April & 0 & 0.0 & 0.0 & 0.0 & 0.0 & 7.8 \\
\hline \multicolumn{8}{|c|}{ Site D2 } \\
\hline \multirow[t]{9}{*}{2010} & March & 54 & 1,718 & 15 & 131 & 83 & 39,018 \\
\hline & April & 0.6 & 95 & 0.2 & 1 & 0.5 & 321 \\
\hline & May & 15 & 1,580 & 10 & 36 & 87 & 307,404 \\
\hline & June & 4 & 577 & 3 & 13 & 6 & 749 \\
\hline & July & 5 & 1,222 & 5 & 5 & 2 & 216 \\
\hline & August & 2 & 265 & 4 & 27 & 0.7 & 240 \\
\hline & September & 3 & 514 & 3 & 42 & 0.4 & 15 \\
\hline & October & 1 & 445 & 0.5 & 6 & 0.1 & 7 \\
\hline & November & 0.2 & 53 & 0 & 0.1 & 0.0 & 0.6 \\
\hline
\end{tabular}


Table 1-5. Monthly loads for monitoring sites at Dazey farm, North Dakota, 2010-15.-Continued

$[\mathrm{N}$, nitrogen; $\mathrm{P}$, phosphorus $]$

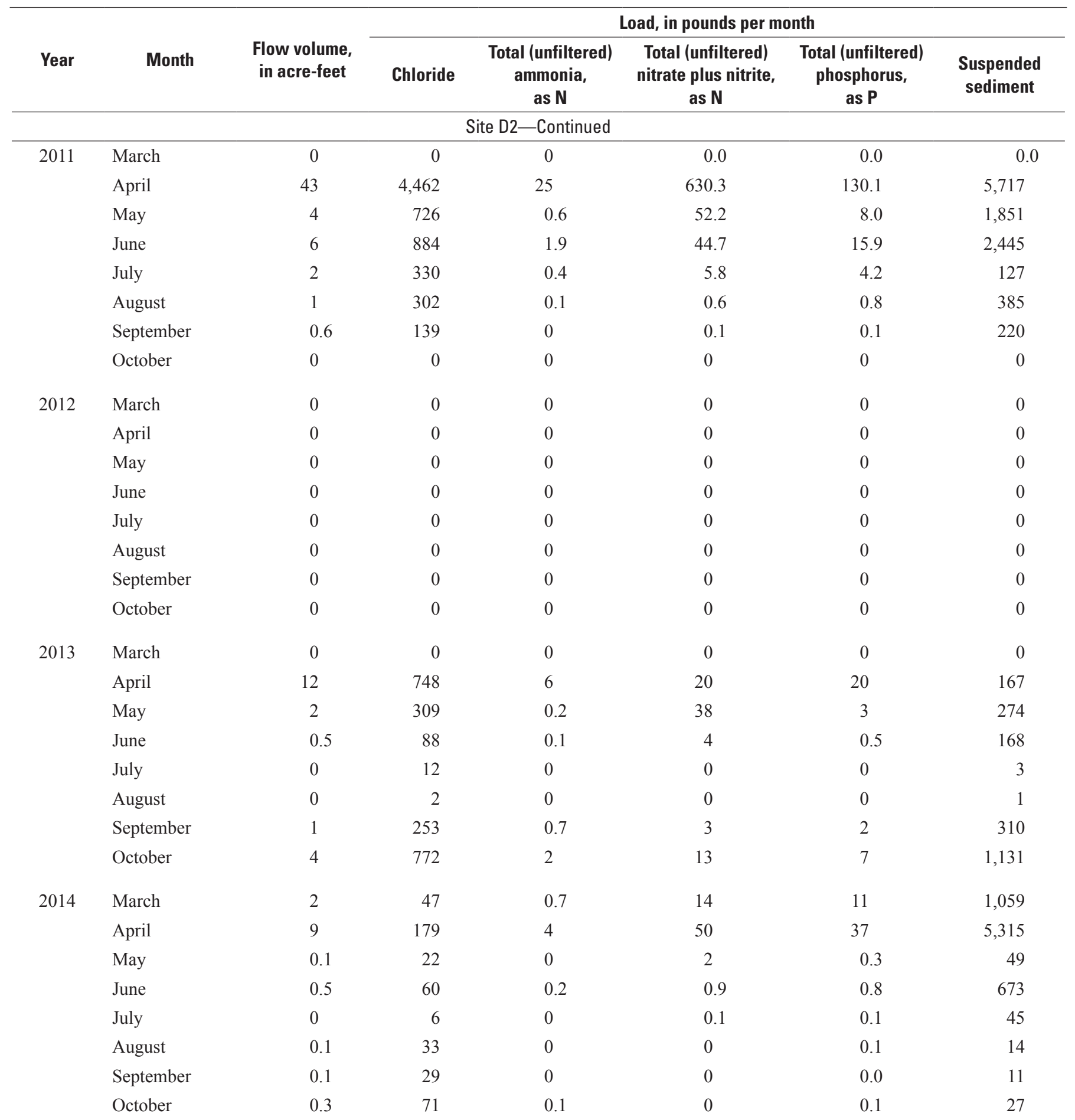


Table 1-5. Monthly loads for monitoring sites at Dazey farm, North Dakota, 2010-15.-Continued

[N, nitrogen; $\mathrm{P}$, phosphorus]

\begin{tabular}{|c|c|c|c|c|c|c|c|}
\hline \multirow[b]{2}{*}{ Year } & \multirow[b]{2}{*}{ Month } & \multirow[b]{2}{*}{$\begin{array}{l}\text { Flow volume, } \\
\text { in acre-feet }\end{array}$} & \multicolumn{5}{|c|}{ Load, in pounds per month } \\
\hline & & & Chloride & $\begin{array}{c}\text { Total (unfiltered) } \\
\text { ammonia, } \\
\text { as } \mathbf{N}\end{array}$ & $\begin{array}{l}\text { Total (unfiltered) } \\
\text { nitrate plus nitrite, } \\
\text { as } \mathbf{N}\end{array}$ & $\begin{array}{c}\text { Total (unfiltered) } \\
\text { phosphorus, } \\
\text { as } \mathbf{P}\end{array}$ & $\begin{array}{c}\text { Suspended } \\
\text { sediment }\end{array}$ \\
\hline \multicolumn{8}{|c|}{ Site D2-Continued } \\
\hline \multirow[t]{6}{*}{2015} & March & 24 & 3,283 & 158 & 61 & 207 & 4,828 \\
\hline & April & 0.3 & 57 & 1.0 & 0.5 & 1 & 53 \\
\hline & June & 0.7 & 86 & 0.4 & 1 & 1 & 1,323 \\
\hline & July & 0 & 3 & 0 & 0 & 0 & 17 \\
\hline & August & 0 & 1 & 0 & 0 & 0 & 3 \\
\hline & September & 0 & 2 & 0 & 0 & 0 & 1 \\
\hline
\end{tabular}

For more information about this publication, contact

Director, USGS Dakota Water Science Center, North Dakota Office

821 East Interstate Avenue

Bismarck, ND 58503

(701) 250-7400

For additional information visit https://nd.water.usgs.gov

Publishing support provided by the

Rolla Publishing Service Center 

